\title{
生體內「メントール,グルクロン酸生成， \\ 量的關係及ビ之ガ葡萄糖「インンュリン」 \\ 俇用ニヨリ受クル影響二就テ
}

\section{日本醫科大學綝理學致堂（主任 西村敬授）}

踏觉科生小松龄言

\begin{tabular}{|c|c|c|c|c|}
\hline & & 目 & 次 & \\
\hline $\begin{array}{l}\text { 緒 諭 } \\
\text { 第 } 1 \text { 編 }\end{array}$ & $\begin{array}{l}\text { 生體內「メントール, } \\
\text { 成〉量的關係二就テ }\end{array}$ & グルクロン酸生 & 第 8 編 & 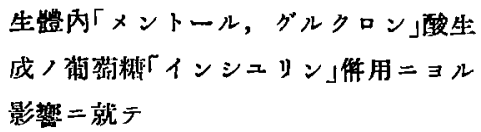 \\
\hline
\end{tabular}

第 2 編 生體內「メントール,グルクロン」酸生結 論

成，單糊颣 $=\Xi$ ル影整二就テ

\section{緒論}

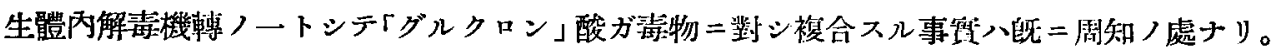
Wiedemann (1877)(1) ガ「カンフル」ヨ與へシ犬ノ尿中二特異ナル酸ノ存在スル 認メ, 且ツ之 二對シ Jaffe $(1878)^{(2)}$ Schmiedeberg u. Mayer (1879)(3) ガ複命「グルクロン」酸ナル名稱フ附 シテ以來, 複合「グルクロン」酸ニ關スル研觉ハ漸次注視七ラルルニ至レリ。

$\mathrm{OH} \mathrm{H} \mathrm{OH} \mathrm{OH}$

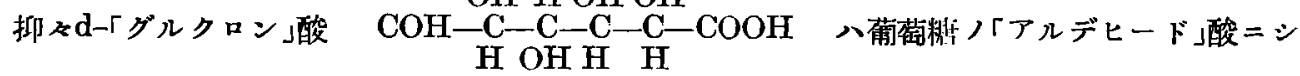
テ, 生體內ニ於テハ遊離シテ存在スルコトナク, 一定ノ物質ト結合狀態ニ於テ存スルモノ=

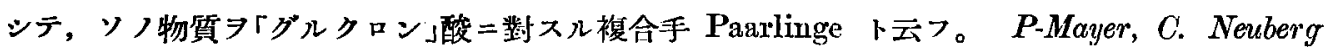
$(1900)^{(4)}$ Hervieux $(1908)^{(5)}$ Tollens $(1900)^{(6)}$ Stern u. Tollens $(1910)^{(7)}$ Conzen $(1919)^{(8)}$ Händel.

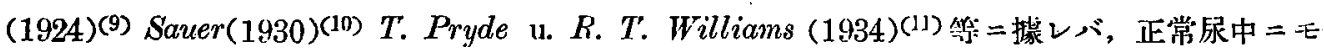
「グルクロン」酸存在ス。此ノ場合多ク八腸管內佫敗產物タル「インドール」スカトール」「フェノ ール」等 $尹$ 複合乎トスルコトハNeuberg u. Mayer $(1900)^{(12)}$ ガ立證セル所ナリ。ソノ他整學 上必要ナル多數ノ倠機化合物ガ生體內二於テ「ダルクロン」酸卜複合スルコト，及ビ化合物中水 酸基 フ受ケ然ル後二襍合スルモノナルコトハ, 既=Neuberg U. Mayer $(1900)^{(13)}$ ガ推論セシ處タ リ。例へバ「インドール」が「インドキシール」,「スカトール」ガ「スカトキシール」ニ「カンフ ル」が「オキシカンフル」ニ「アンチピリン」ガ「オキシアンチビリン」變化セル後「グリクロン」 酸卜複合スルガ如シ。

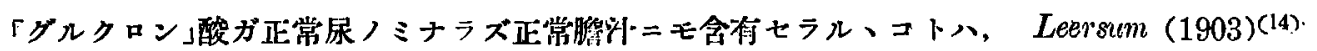


Bial $(1904)(1906)^{(15)}$ Blumenthal $(1906)^{(16)}$ /證明七ルガ如ク坂非(1935)(17)壬亦同様ノ事賽 尹立證七リ。

次二複合「グルクロン」酸ハ生體內何レノ践器組織ニ於テ生成セラルルヤノ閒題二關スル先人

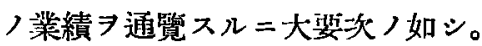

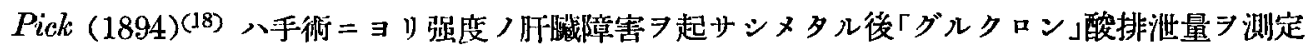
セルニ大ナル變化ナカリショ以テ，肝䤘ハ「グルクロン」酸生成二八重要ナラズトシ,Embden u.

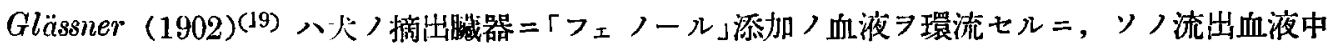

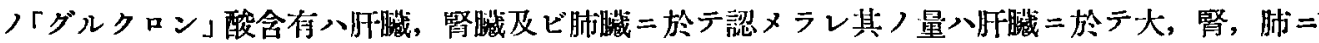
於テ小ナリト云フ。Gautice u. Hervieux $(1907)^{(20)}$ 八蛙ニ「インドール」ヨ注射セルニ,ソノ

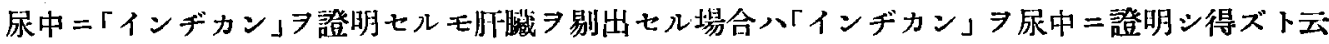

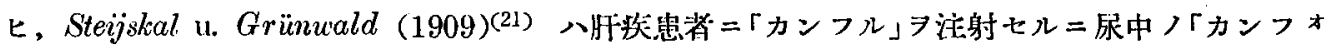
グルクロン」酸量八正常二比シ滅少セりト云フ。Chiary u. Caille $(1912)^{(22)}$ ハ「グルクロン」酸

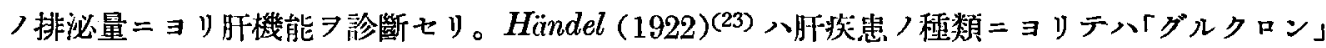
酸排使八低下スト云ヒ, Mann U. Magath $(1924)^{(24)}$ ハ「フェノール」複合ノ速度ハ畈剔出前後二 於テ何等ノ變化ナキコトヨリ，朋裁ハ「グルクロン」酸複合二八重要ナラズトナシ，千集(1928）

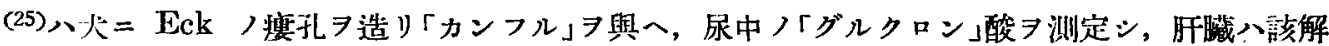

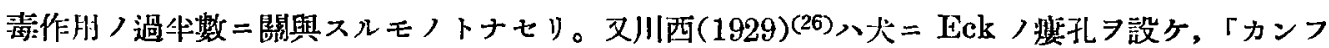

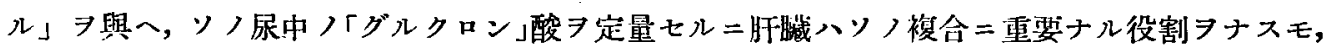

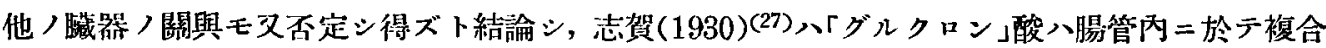

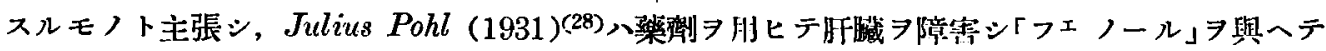
「フェノールグルクロン」酸ヨ测定セルニ,「グルクロン」酸複合（八一定ノ場所ナシトノ結論二

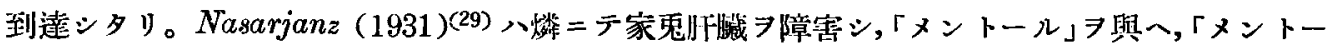
ル,グルクロン」酸ヨ定量スル二, 明二減少スルモ,ソレ八食邻ノ影響二低ルモノナラントシ,

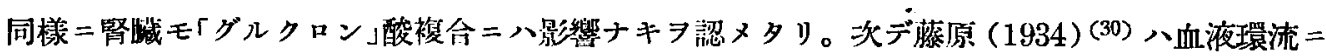
「メントール」ヨ加へ肝, 腎, 肺ア環流スルニ生成「グルクロン」酸量八肝睵二於テ最モ强ク, 次

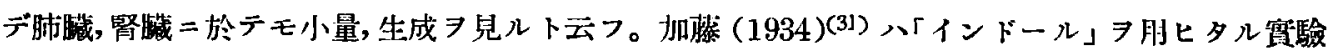

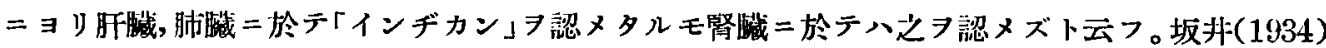
(32) ハ「メントール」ヨ與へタル家鬼集汁ョリ「メントール,グルクロン」酸ヨ分離シ, 且ツ高度

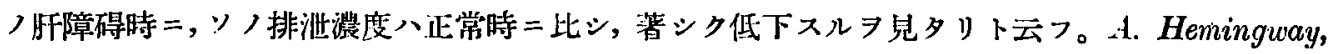
J. Pryde, R. T. Williams $(1934)^{(33)}$ 八環流賽驗ノ結果肝践ハ「グルクッン」酸複合二參與スル

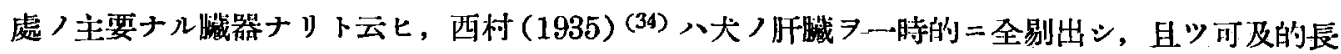

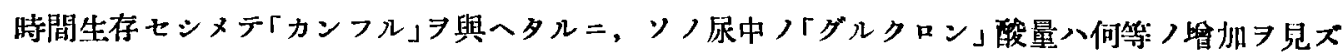
シテ「カンフル」ヨ注射セザル場合ト同榜ナルヨ認メタリ。 


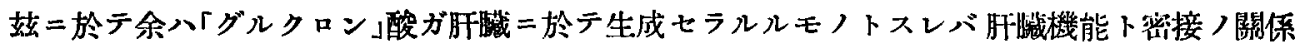
ヨ有シ，且ツ「グルクロン」酸ト八其ノ構造上極メテ良ク類似セル單糖類が「グルクロン」酸生成

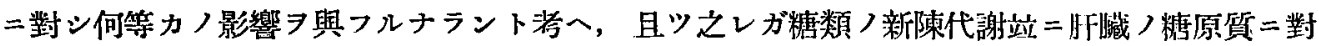
シ，重大ナル關係ア有スル「インシュリン」ト葡萄糖トノ件湖ニヨリ，如何二變化七ラルルカ 椝知セントシ，賽驗

\section{第 1 編 生體內「メントール,グルクロン酸生成ノ量的關係二就テ}

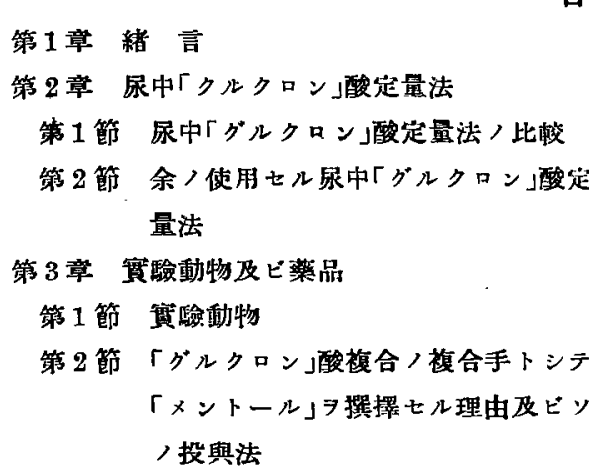

第 4 章「メントール」ガ複合「ダルクロン」酸ト シテ尿中二排㳔サル几場合，時間及ビ 量的關係
次

$$
\begin{aligned}
& \text { 筝1節 本時二於ケル家鬼尿中，「グルクロ } \\
& \text { ン」酸量 }
\end{aligned}
$$

排泄率

第 3 節 家兔體内二於ケル「グルクロン」酸生

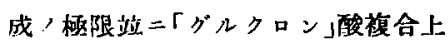
ヨリ見タル家鬼る「メントール」耐量 第 4 節 一定閣隔(72特間) ル」ヨ速續頁荷七ル場合/生成「グ ルクロン」酸量

第 5 音 總括及ビ拷察

\section{第 1 章 緒言}

生體二投與サレタル「メントール」ハ主トシテ朋践ニ於テ「グルクロン」ト複命セラレ,「メント ール,グルクロン」酸トシテ排泄セラルルコトハ周知/事筫ナリ。

而シテ生體ニ「メントール」ヨ與ヘシ時ノ「メントール,グルクロン」酸生成ノ量的關係二就テ

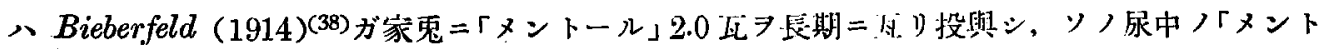

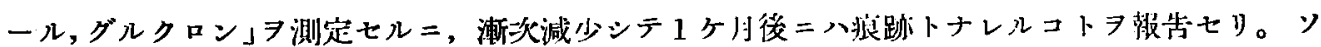

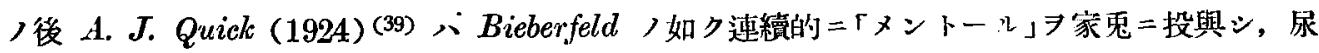

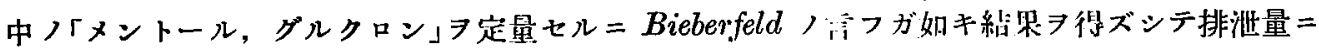

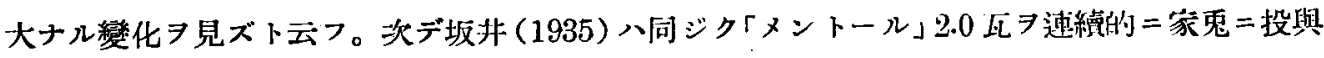

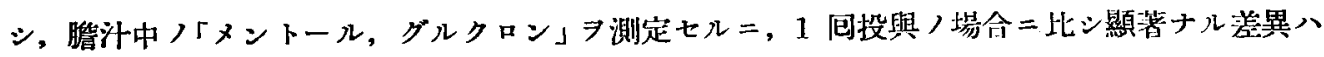
認メ難シト云ヘリ。以上ハ同量ノ「メントール」連續投與セル場合ナレドモ,「メントール」投 與 ᄏ漸次增量シ投與セルモノニハ, A. J. Quick $(1924)^{(39)}$ ガ家蒐二菆初 0.5 瓦次デ 1.0 瓦卜增

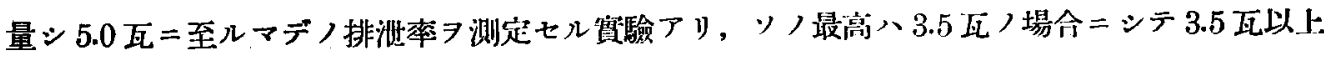

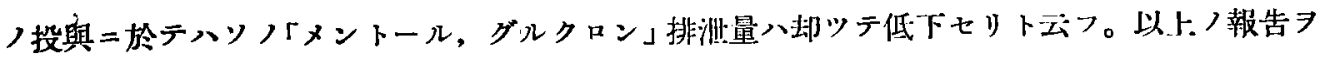

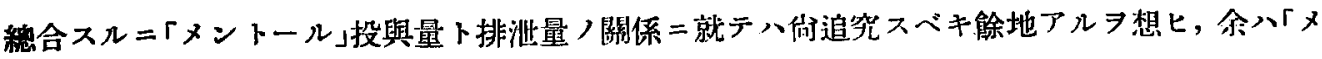




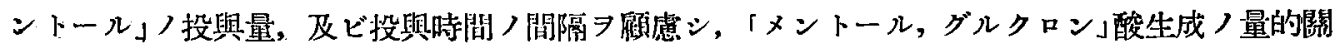

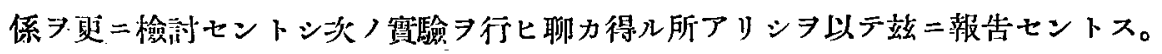

\section{第 2 章 尿中ノ「ダルクロン」酸定量法}

\section{第 1 節 尿中ノ「グルクロン」酸定量法ノ比較}

從來扫ヒラレッッアル沓中ノ「グルクロン」酸ノ定量法ハ「グルクロン」ノ旋光性, 還元性, 沈 澱性, 著色反隹等 $ᄏ$ 利州七ルモノニシテ, 何レモ, 椱合「グルクロン」酸ノ椱合物質 $尹$ 加水分解 シ「グルクロン酸ヨ遊離セシメタル後, 之ア定星スルモノトス。之ガ䨘施二當リテハ種タナル

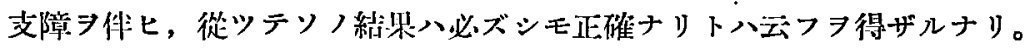

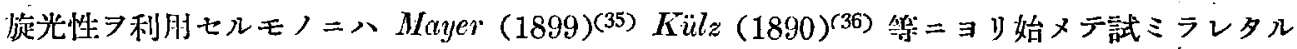
最モ占キ方法アリ。複合「グルクロン」酸八光學的ニ八左旋性ナルモ，遊離「グルクロン」酸八右 旋性ナル

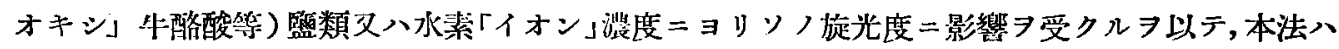
ソノ補正容易ニアラズ。

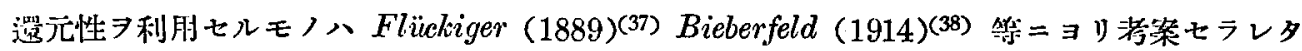
ルモノナレドモ，本法斗實施スル二當リテハ，尿中ノ還元物質（葡萄糖，尿酸，「クレアチン」

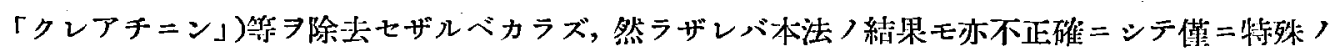
衫命「グルクロン」酸/定量二適當セルノミナリ。A．J.Quick $(1924)^{(39)}$ ハ「メントール，グ

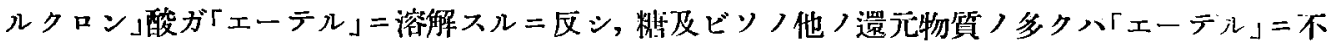
溶性ナル

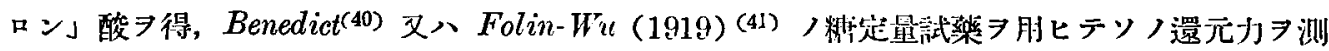
分シ以テ「グルクロシ」酸ノ定量 フ行へリ。

沈測法ニヨルモノ八鉛醋及ビ「アムモニヤ」ヨ「グルクロン」酸浴液二加へテ「グルクロン」酸ヨ

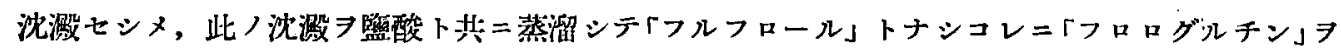
添加シテ,「フルフロール, グルチード」トナシ,ソフ車量习测定ス。此ノ方法八濾液卜共=浱 暨酸 多星ナラザレバソノ結果ハ不正確トナル。Händel (1924)(42)八ト記ノ沈澱法〉缺點ヨ補ハント シ, 重量 7 测定スル代リニ, 沃度滴定法ヨ施セリ。郎チ上記ノ如クシテ「フルフロール」ニマデ

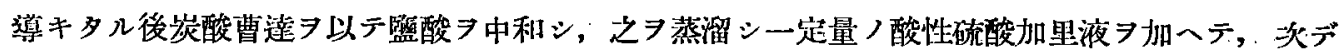
沃度溶液

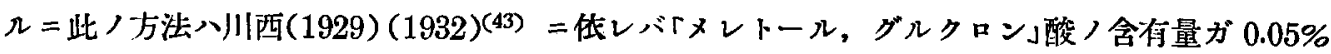
以下ナルトキハ测定不可能ニシテ 0.1-1.0\%ナル場合八頁ノ含售量ノ4-22\% 檢出可能ナリト 云>

里色反應)研究八Nicolas $(1906)(44)$ Goldschmidt $(1910)^{(45)}$ 等 $-1080-$ 


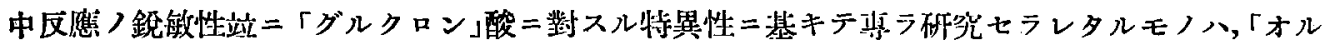

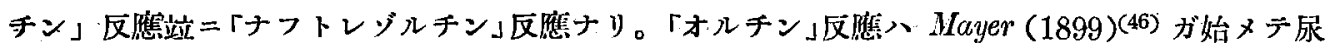

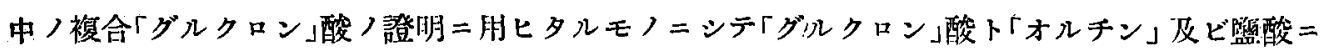
ヨリテ生ズル色素ガ「アミールアルコール」ニ抽出七ラレ, 之綠つ著色卜特有つ吸收線トヨ與

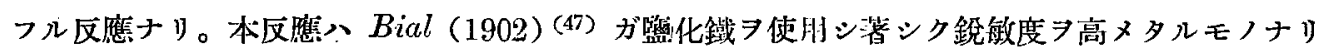
又 B. Tollens (1908)(48) ハ「グルクロン」酸ガ「ナフトレジルチン」ト作湖シ 1 種)色素ア生ジ 之ガ「エーテル」吸收セラレ,奏麗ナル紫ノ落色卜特哄ノ吸收線シ現ハスコトア見出シタリ。シ カル二其 後 Neuberg (1908) Neuberg u. Mandel (1908)(1909)(1910)(49, ノ研究=低り本反 應八「グルクロン」酸特住ノモノニアラズシテ, 殊ニ「アルデヒード」酸站二「ケト」酸等一般 こ「カーボニル」酸二陽性ナル事賽ガ判刖七ラレタリ。晌 Veuberg u. Saneyoschi (1911) (50)

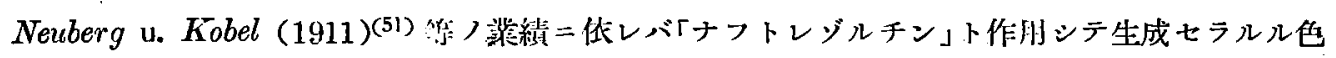

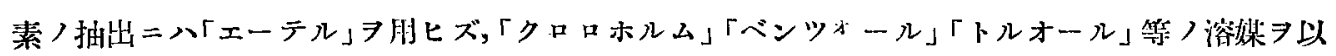

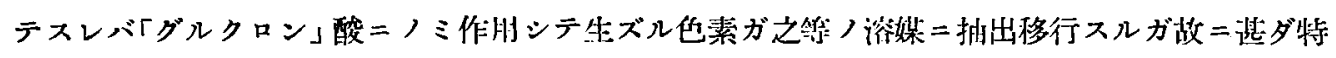

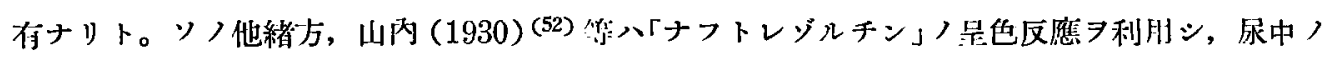
「グルクロン」酸ノ定量法ヨ發表セリ。

余八余ノ實驗/目的タル栫類投與ノ「グルクロン」酸生成＝及ボス影響习驗セントスルニ八, 本法最モ道當ナルベキヨ信ジタル故, 複命「グルクロン」酸生成ノ手段トシテ凡テ「メントール」

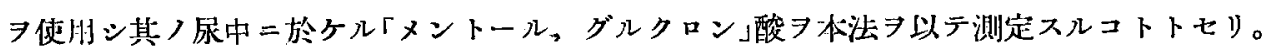

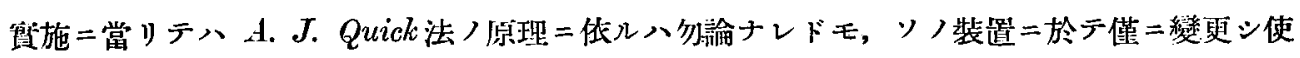

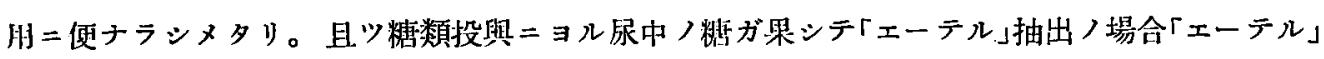

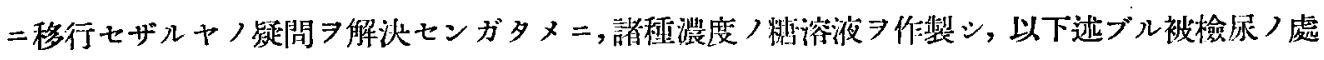

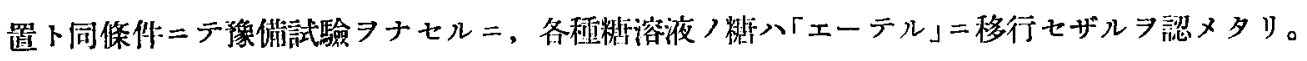

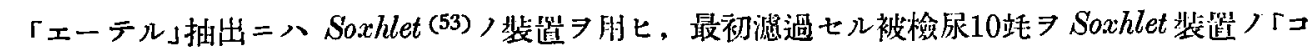

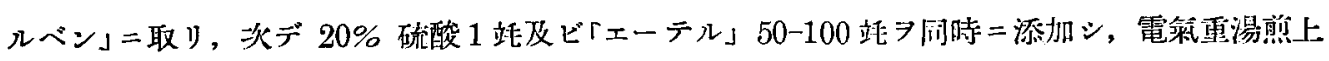
$=テ 60 \mathrm{C}^{\circ}$ 前後 溫度

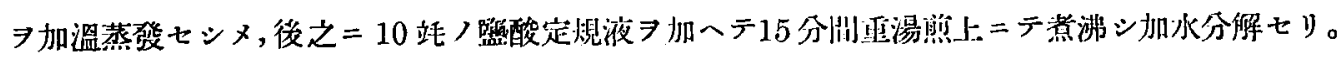

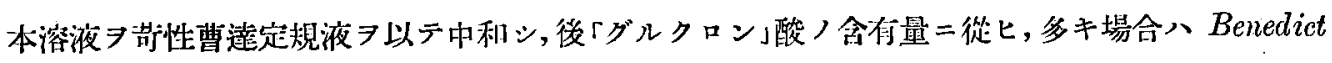

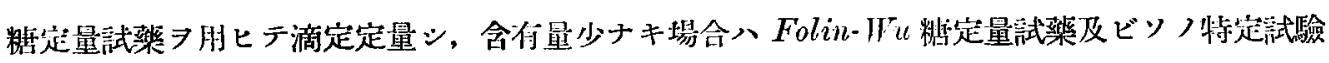

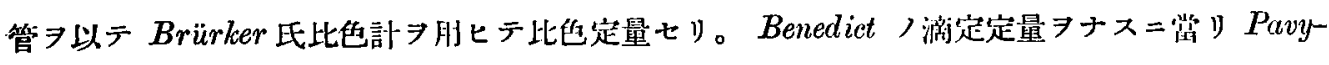

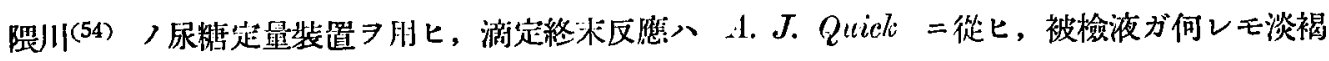

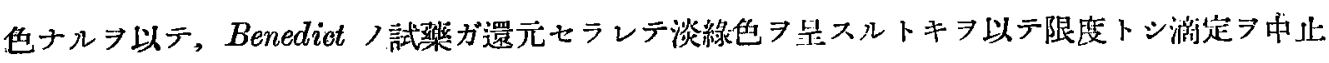
セリ。算定方法ハBenedict 試藥 1 站

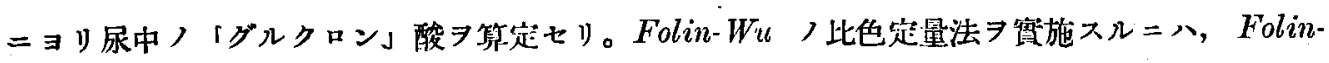




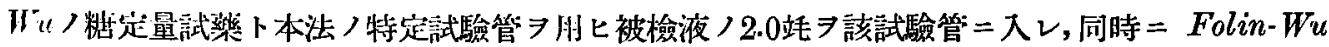

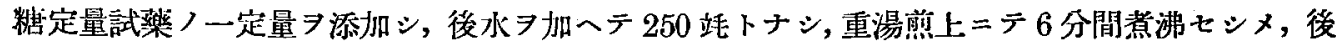

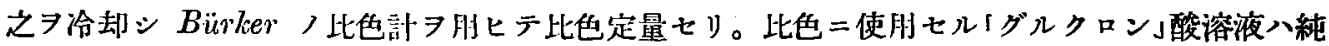

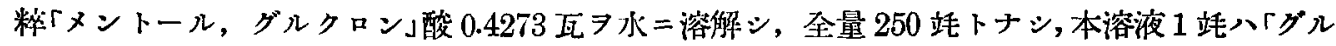

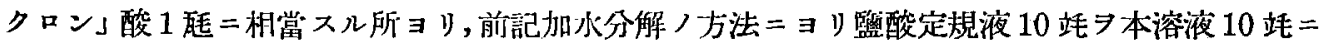

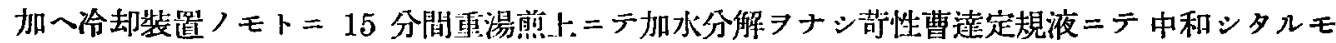
ノフ比色定量ノ對照液トナヒり。

\section{第 3 章 實驗動物及ビ藥品}

\section{第 1 節 共 験 動 物}

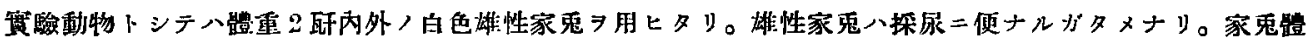
重ノ測定八何レモ排尿後每日同㭙副二行へリ。

\section{第 2 節 動物餇育法及ビ採尿法}

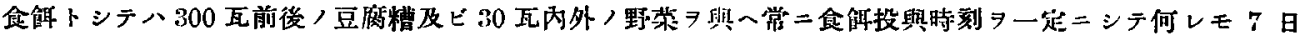

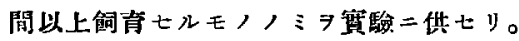

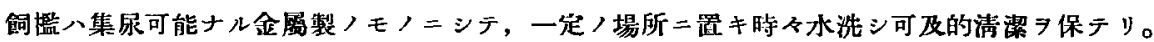

探尿法八一定時刻二消素七ルネラトン「カテーテル」ヨ以テ完全排尿セシメタル後, 動物

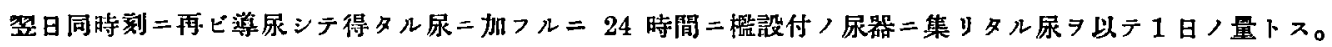

\section{第3 節「グルクロン」酸複合ノ複合手トシテ「メントール」}

\section{ヨ選擇セル理由及ビソノ投與法}

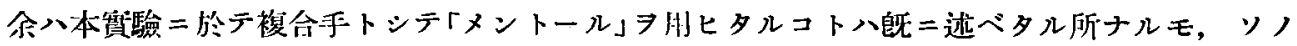
選擇理由八大恐次/如キモノナリ。

(1)「メントール」ハ主トシテ「グルクロン」酸ト複命シテ排泄セラルルモノナリ。

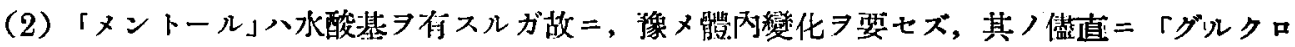
ン酸ニ複命ヒラル。

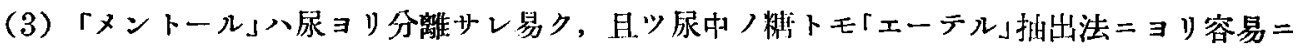
分離サレ得。

（4）「メントール J 對シテ動物ハソノ耐谷力比校的强ク, 從ツテソノ大量扫ヒラル。

(5)「メントール」ハソノ吸收比較的迅速良好ナリ。

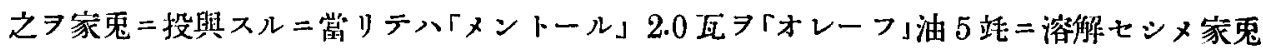
背部ノ皮下゙=注射七リ。

余八本實驗中

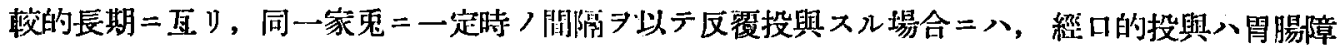

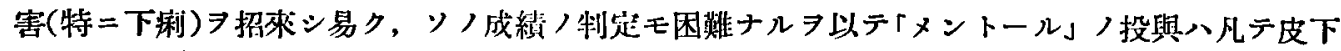


注射ト七リ。

\section{第 4 節「メントール」ノ中毒症狀二就テ}

同一家鬼二反䧗「メントール」ヨ投與スル場合ニハ中毒症狀习招來スルモノナリ。

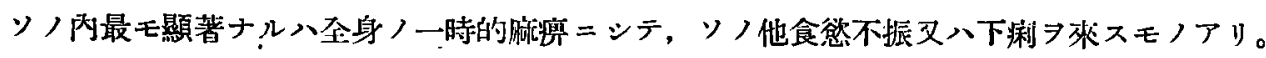

A. J. Quick (1924) (55) =依レバ「メントール」/家鬼=對スル致死量八 4.0 万至 5.0 后ナリト 云ヒ, Fromm u. Clemens (1901) (56) 八元氣旺盛ナル家鬼ハ5庁ノ「メントール」ノ負荷二耐二 ト云フ。

\section{第4 章「メントール」ガ複合「グルクロン」酸トシテ尿中ニ}

\section{排泄サルル場合ノ時間及ビ量的關係}

平時及ビリメントール」2.0瓦ヨ投與セル場合ノ家鬼尿中「グルクロン」酸量唯祭セントシ次ノ

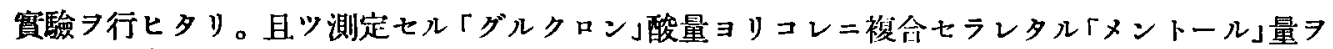
算定シ「メントール」/投與量ト排泄量トノ關係 $フ$ 明 $=七 り 。$

\section{第 1 節 平時ニ於ケル家鬼尿中ノ「グルクロン」酸量}

「メントール」注射前日ノ尿中ノ「グルクロン」酸量八第 1-5例 7 是ル $=$ ，「メントール」注射後 第 3 日ニ於ヶルモノト大差ナキヨ知レリ。(第 1 表站及ビ附圖參照)

郎チ「メントール」投與前日ト注射後第 3 日トニ於ケル，尿中ノ「グルクロン」酸八相近キ數量

$$
\text { 第 } 1 \text { 表 }
$$

「メントール」2.0瓦注射二ョル場合ノ「メントール」排泄時間，排泄量及排泄华

\begin{tabular}{|c|c|c|c|c|c|c|c|}
\hline $\begin{array}{l}\text { 家 } \\
\text { 鬼 } \\
\text { 㓡 } \\
\text { 數 }\end{array}$ & $\begin{array}{l}\text { 䨘 } \\
\text { 月, }\end{array}$ & 日，時 & 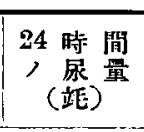 & 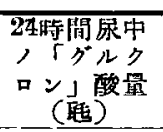 & 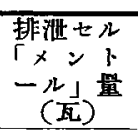 & 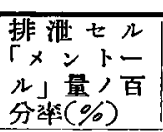 & $\begin{array}{c}\text { 備 考 } \\
\text { 中琵症狀 } \\
\text { ，有無 }\end{array}$ \\
\hline \multirow{6}{*}{ I } & & 家 鬼 令 & 2.145 (刵) & & & & \\
\hline & $\begin{array}{l}4 / 1 \mathrm{~V} \\
5 / \mathrm{IV}\end{array}$ & $\begin{array}{l}1^{11} 30^{\mathrm{m}}\left(\mathrm{P}_{12}\right) \\
1^{\mathrm{h}} 30^{\mathrm{m}}\left({ }^{\prime \prime}\right)\end{array}$ & 200 & 19.20 & $(-)$ & & $(\rightarrow$ \\
\hline & & 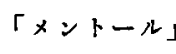 & 2.0 瓦皮下 & 生射 & & & \\
\hline & $\begin{array}{l}5 / \mathrm{IV} \\
6 / \mathrm{IV}\end{array}$ & $\begin{array}{l}1^{11} 30^{\mathrm{nn}}(1 /) \\
1^{\mathrm{h}} 30^{\mathrm{m}}(/ /\end{array}$ & 270 & 509.22 & \multirow{2}{*}{0.59} & \multirow{2}{*}{29.5} & $(-)$ \\
\hline & $\begin{array}{l}\text { 6/1V } \\
7 / 1 \mathrm{~V}\end{array}$ & $\begin{array}{l}1^{\mathrm{h}} 30^{\mathrm{m}}(/ / \\
1^{\mathrm{h}} 30^{\mathrm{m}}(/ /)\end{array}$ & 215 & 267.03 & & & $\rightarrow$ \\
\hline & $\begin{array}{l}\text { 7/IV } \\
\text { B/IV }\end{array}$ & $\begin{array}{l}1^{11} 30^{m}(1 / \\
1^{1} 30^{m}(1 /\end{array}$ & 200 & 22.00 & $(\rightarrow)$ & & $\rightarrow$ \\
\hline \multirow{6}{*}{ II } & & 家 鬼 今 & 2.140 (䣶) & & & & \\
\hline & $\begin{array}{l}5 / \mathrm{IV} \\
6 / \mathrm{IV}\end{array}$ & $\begin{array}{l}2^{\mathrm{n}} 3^{\mathrm{m}}\left(\mathrm{c}^{\prime \prime}\right) \\
2^{\mathrm{n}} 3^{10 \mathrm{~m}}(1 / 1)\end{array}$ & 30 & 5.10 & $\Leftrightarrow$ & & $\rightarrow$ \\
\hline & & 「メントール & 2.0 瓦皮下 & 生射 & & & \\
\hline & $\begin{array}{l}6 / \mathrm{IV} \\
7 / \mathrm{IV}\end{array}$ & $\begin{array}{l}2^{11} 30^{11}(1 / \\
2^{11} 30^{m}(1 /)\end{array}$ & 190 & 428.26 & \multirow{2}{*}{0.46} & \multirow{2}{*}{23.0} & $(\rightarrow)$ \\
\hline & $\begin{array}{l}\text { 7/IV } \\
\text { 8/IV }\end{array}$ & 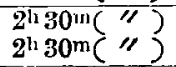 & 180 & 169.74 & & & $(-)$ \\
\hline & $\begin{array}{l}\text { 8/IV } \\
\text { 9/IV }\end{array}$ & $\begin{array}{l}2^{\mathrm{h}} 30^{\mathrm{m}}(1 / \\
2^{n} 0^{\mathrm{m}}\left({ }^{\prime \prime}\right)\end{array}$ & 150 & 16.56 & $\leftrightarrow$ & & $\rightarrow$ \\
\hline
\end{tabular}




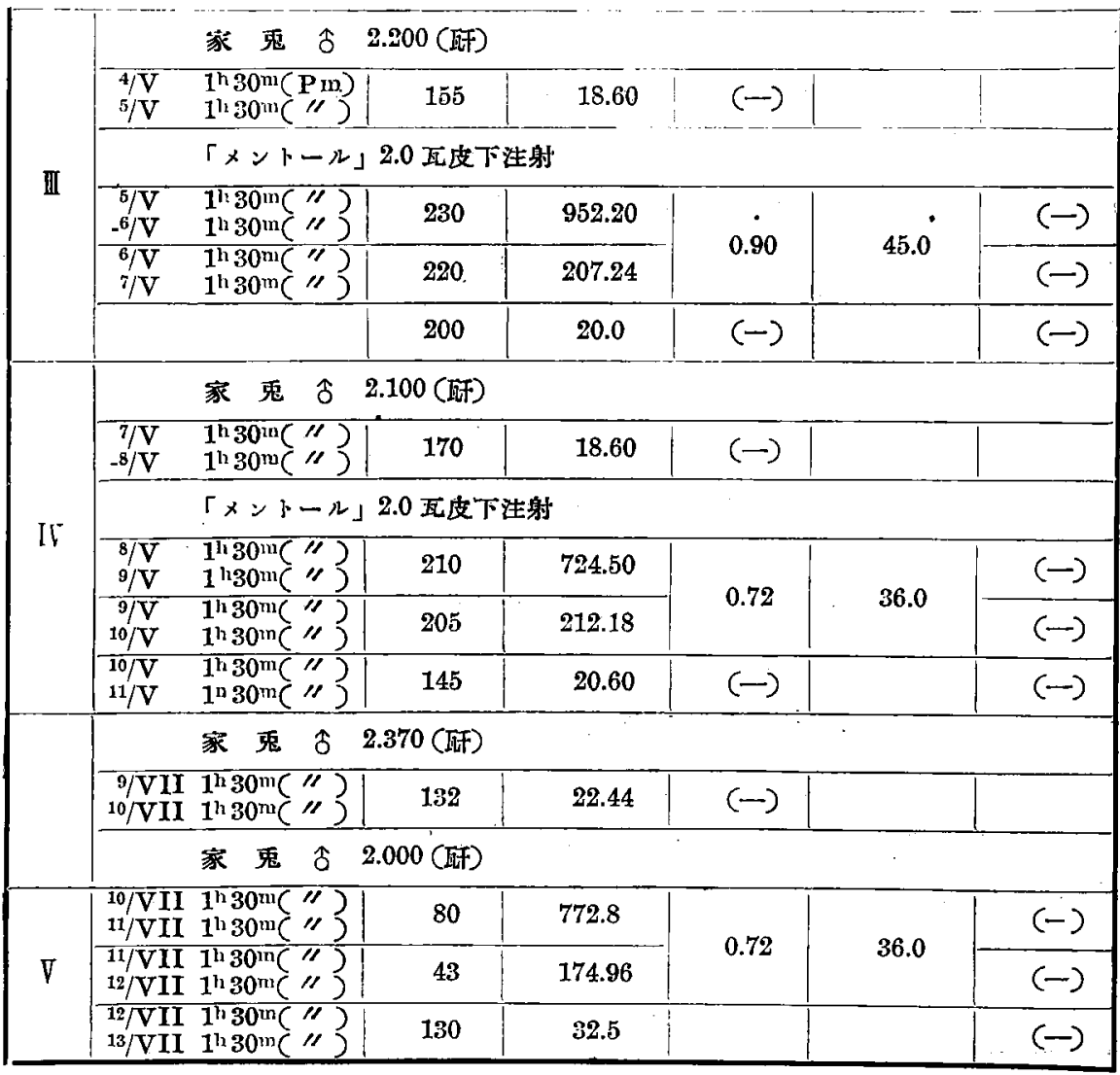

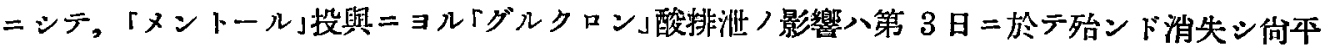
常尿中ニ於テモ「エーテル」ニ移行スベキ複合「グルクロン」酸ノ輕度二存スルヨ知ル。而シテ尿

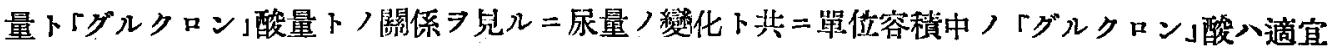
增減シテ 1 日ノ總量二於テ略飞等シカラントスル傾向アルガ如シ。

\section{第 2 節「メントール」 2.0 瓦フ注射セル場合ニ於ケル 24 時間單位ノ}

\section{尿中ノケグルクロン」酸排泄量竝ニ「メントール」排泄率}

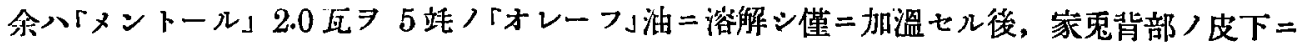
注射シ、ソノ後 24 時間ア單位トシテ採尿シ,ソノ尿中ノ「グルクロン」酸量 前 24 時間ノ尿二就イテモコレラ゙测定シ以テ比较對照ノ为二俱セリ。ソノ賽驗成績入次ノ如シ。 （第 2 表參照）

「メントール」注射後ノ「グルクロン」酸排泄ノ狀沉 724 時間 時間队二最モ多量ヨ，沃？ 24 時間二八初メノ 24 時閶ヨリハ著シク減少セルモ倘本日二比シ

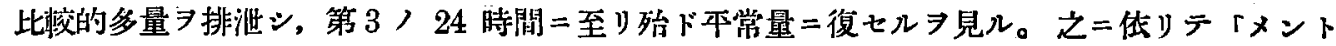




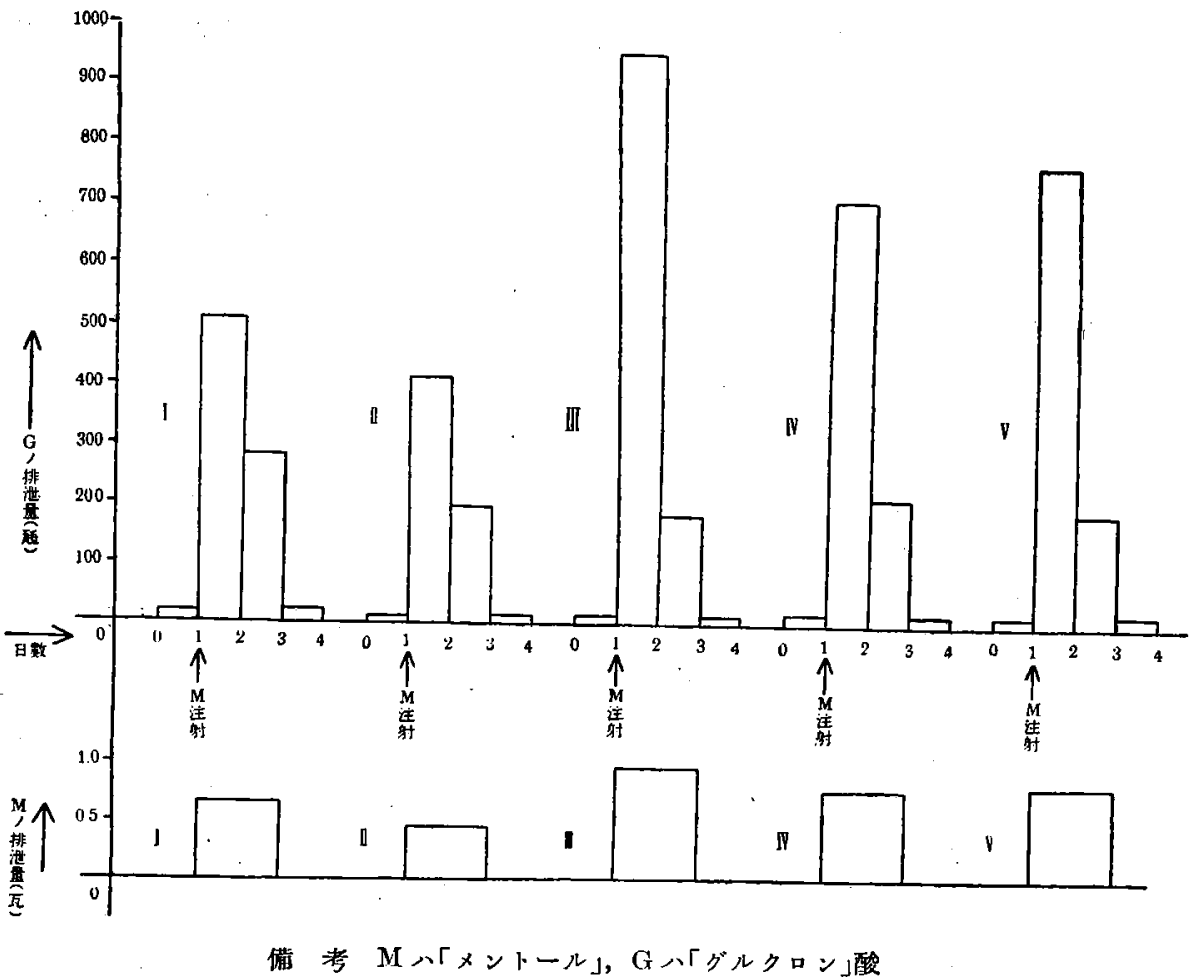

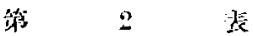

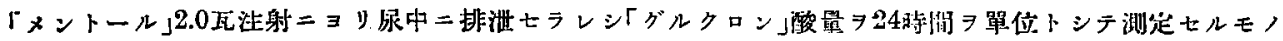

\begin{tabular}{|c|c|c|c|c|c|c|c|c|c|}
\hline \multirow{2}{*}{$\begin{array}{l}\text { 菑䲆 } \\
\text { 家鬼 } \\
\text { 列數 }\end{array}$} & \multirow{2}{*}{ 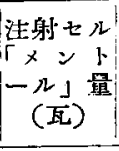 } & \multicolumn{4}{|c|}{ 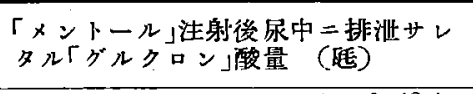 } & \multirow{2}{*}{\multicolumn{3}{|c|}{ 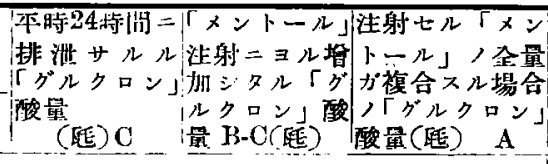 }} & \multirow{2}{*}{ 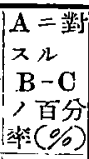 } \\
\hline & & $0-24$ 㭙 & ! & $24-48$ 持 & $\begin{array}{c}0-48 \text { 封 } \\
\end{array}$ & & & & \\
\hline 1 & 2.0 & 509.22 & & 267.03 & 776.25 & 41.20 & $7: 3.05$ & 2480 & 29.5 \\
\hline 2 & 2.0 & 428.26 & & 169.74 & $59 S .00$ & $\therefore 1.6 i 4$ & 576.36 & 2480 & 23.0 \\
\hline 3 & 2.0 & 952.20 & & 207.24 & 1159.44 & 88.6 & 1120.84 & 2480 & 45.0 \\
\hline 4 & 2.0 & 724.50 & 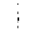 & 212.18 & 936.68 & 39.2 & 897.48 & 2480 & 36.0 \\
\hline 5 & 2.0 & 772.8 & & 174.96 & 947.76 & 54.94 & 892.82 & 2480 & 36.0 \\
\hline
\end{tabular}

ール」ヨ皮下二注射セル場合ソレガ「グルクロン」酸ニヨリ複合セラレテ尿中二排淮シ終ルハ48 時間以队ナリト考人得。

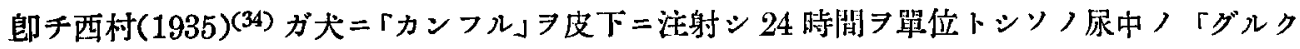
ロン」酸ノ排泄量 7 測定シ注射後最初ノ 24 時間二「グルクロン」酸排泄量最モ多ク, 第 3 ノ24時 間ニ八，平常時(注射前日)ノ量二復歸 八中毒症狀卜認ムルモノナク平裳卜異ル所ナカリキ。 
今投與サレタル「メントール」ト排泄サレタル「グルクロン」酸トノ量的關係习檢討スル $=, 1$ 分 子・ノメントール」ハ1分子「グルクロン」酸ト複合シテ，複合「グルクロン」酸トシテ排泄年レ再 ビ 1 分了・ノグルクロン」酸ヨ遊離ス。「メントール」/分子式八 $\mathrm{C}_{10} \mathrm{H}_{20} \mathrm{O}=$ シテ，ソ/原子量习 $\mathrm{C}=12, \mathrm{H}=1, \mathrm{O}=16$ トスレバりノ分子星入 156 ナリ。「グルクロン」酸ノ分子式八 $\mathrm{C}_{16} \mathrm{H}_{10} \mathrm{O}_{7}$ シシテ，ソ/分子量八同様/訃算=ョリ194ナリ。郎チ「メントール」ニ「グルクロン」酸ノ比ハ $1: 1.24$ ナリ。今「メントール」注枋後 48 時間以內二排泄サレタル「グルクロン」酸量ヨリ, 平日 排泄サルル48 時問量(投與前日及ビ投與啳第 3 日ノ「グルクロン」酸量/總和) ヨ減ジタルモ ノヨ「メントール」ジ注射セルタメ二,習扣セシ「ダルクロン」酸量ト見做シ之ガ注射サレタル「メ ントール」ノ全量ガ「グルクロン」酸ト複合スト假定シタル場合二複合スベキ「グルクロン」酸量

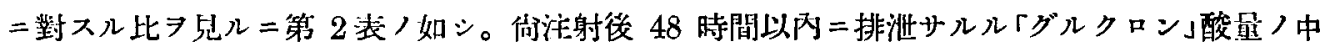
其ノ大部分八注射淩 24 時間以內二排沘サルルモノナルコトア知ル。

\section{第 3 節＼cjkstart家兔體内ニ於ケル「グルクロン」酸生成ノ極限竝ニ「グルクロン」 酸複合上ヨリ見タル家兔ノ「メントール」耐量}

A. J. Quick $(1924)^{(55)}$ 八芜鬼二對スル「メントール」致死量 7 4.0-5.0瓦ナリト云ヒ, Fromm u. Clemens $(1901)^{(56)}$ ハ「メントール」5.0瓦八健康家鬼二於テ負荷二耐フト云へリ。

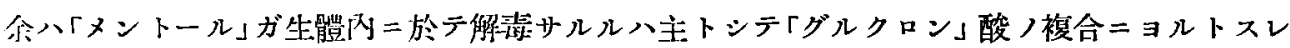
バ，其ノ致死媐若クハ中潗:量卜複合「グルクロン」酸量卜ノ閒二何等カノ關係アルナラント信ジ 家鬼ニ「メントール」ノ種ぬノ量ヨ投與シ，ソノ排泄「メントール，グルクロン」酸量ヨ测定シ以 テ其〉量的關係 7 調㱏シタリ。

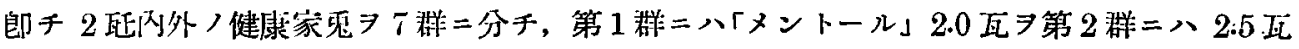

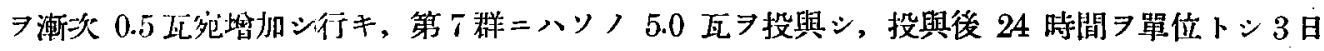
開尿中ノメントール,グルクロン」ヨ测定シタリ。今排沘サレタル「メントール，グルクロン」

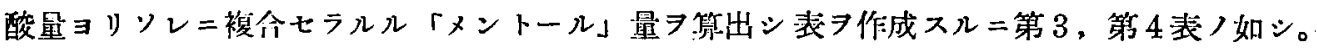
(第 3,4, 裁參紧)

畞チ 3.5 瓦ノ「メントール」ヨ投與シタルトキ「グルクロン」酸二複合サレテ排泄サルル「メント ール了量八 1.88 瓦內外ニシテ, 投與「メントール」量ガ 3.5 瓦ョリ多クトモ少クトモ, ソノ排淮 量八低下スルョ見ル。

少投與「メントール」量二對スル複合「グルクロン」酸中ノ「メントール」量ノ百分比入此/ 3.5

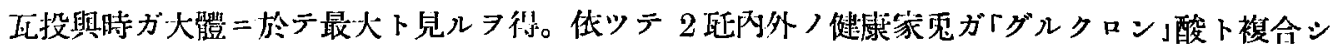
テ排㴹シ得ル「メントール」/1日量/掫大八大體 1.88 瓦附近ナルア知ル。

然ル = Quick 八上記ノ如ク「メントール」致死量ハ4-5.0 瓦ナリト言ヒヌ 3.5 瓦ニシテ諸種 ノ中毒症狀 $ヨ$ 發現スト云フ。余ノ鼻驗ニ於テモ又第 3 表ニ於テ見ラルルガ如ク 3.5 瓦以上

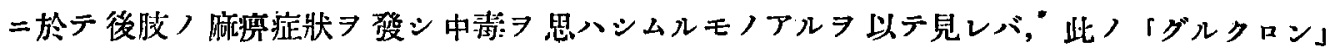


第 3 表 (其, 1 )

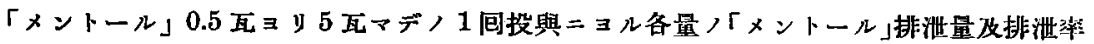

\begin{tabular}{|c|c|c|c|c|c|c|c|}
\hline $\begin{array}{l}\text { 家 } \\
\text { 鬼 } \\
\text { 峢 } \\
\text { 數 }\end{array}$ & 菑覽期間 & $\begin{array}{l}\text { 投 } \\
\text { 県 } \\
\text { 期 } \\
\text { 旦 }\end{array}$ & 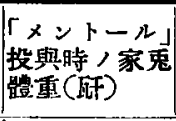 & $\left|\begin{array}{c}x ン ト-\varkappa \\
\text { 投與量 } \\
\text { (酉) }\end{array}\right|$ & 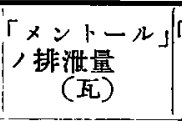 & 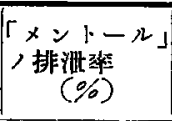 & 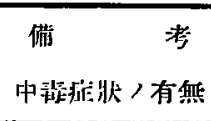 \\
\hline $\begin{array}{l}1 \\
2 \\
3 \\
4 \\
5\end{array}$ & $\begin{array}{c}27 / \mathbf{X} \mathbf{X}-30 / \mathbf{I X} \\
28 / \mathbf{X}-1 / \mathbf{X} \\
28 / \mathbf{X}-1 / \mathbf{X} \\
1 / \mathbf{X}-5 / \mathbf{X} \\
2 / \mathbf{X}-6 / \mathbf{X}\end{array}$ & $\begin{array}{l}28 / \mathbf{I X} \\
20 / \mathbf{I X} \\
20 / \mathbf{I X} \\
2 / \mathbf{X} \\
3 / \mathbf{X}\end{array}$ & $\begin{array}{l}2.200 \\
2.400 \\
2.300 \\
2.000 \\
2.100\end{array}$ & $\begin{array}{l}2.5 \\
2.5 \\
2.5 \\
2.5 \\
2.5\end{array}$ & $\begin{array}{l}1.48 \\
1.10 \\
1.25 \\
0.95 \\
0.83\end{array}$ & $\begin{array}{l}59.1 \\
44.2 \\
50.0 \\
38.1 \\
33.3\end{array}$ & $\begin{array}{c}+, " \\
" 1 \\
" 1 \\
" 1\end{array}$ \\
\hline \multicolumn{5}{|c|}{ 「メントール」ノ平均排泄量 } & $1.12 \div$ & 44.9 & \\
\hline $\begin{array}{r}6 \\
7 \\
8 \\
9 \\
10\end{array}$ & $\begin{array}{l}22 / \mathbf{X}-26 / \mathbf{X} \\
22 / \mathbf{X}-26 / \mathbf{X} \\
25 / \mathbf{X}-20 / \mathbf{X} \\
29 / \mathbf{X}-2 / \mathbf{X} \mathbf{I} \\
30 / \mathbf{X}-3 / \mathbf{X I}\end{array}$ & $\begin{array}{c}23 / \mathbf{X} \\
23 / \mathbf{X} \\
/ \mathbf{X} \\
30 / \mathbf{X} \\
1 / \mathbf{X} \mathbf{I}\end{array}$ & $\begin{array}{l}2.300 \\
2.100 \\
2.350 \\
2.200 \\
2.150\end{array}$ & $\begin{array}{l}3.0 \\
3.0 \\
3.0 \\
3.0 \\
3.0\end{array}$ & $\begin{array}{l}1.88 \\
2.30 \\
1.12 \\
0.76 \\
2.04\end{array}$ & $\begin{array}{l}62.5 \\
76.8 \\
37.4 \\
25.4 \\
68.0\end{array}$ & $\begin{array}{c}+11 \\
11 \\
11 \\
11\end{array}$ \\
\hline \multicolumn{5}{|c|}{ 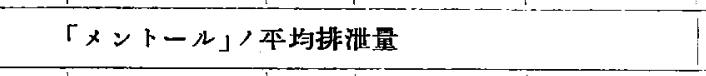 } & 1.62 & 54.0 & \\
\hline $\begin{array}{l}11 \\
12 \\
13 \\
14 \\
15\end{array}$ & $\begin{array}{l}22 / \mathbf{X}-26 / \mathbf{X} \\
22 / \mathbf{X}-26 / \mathbf{X} \\
25 / \mathbf{X}-29 / \mathbf{X} \\
29 / \mathbf{X}-3 / \mathbf{X I} \\
30 / \mathbf{X}-3 / \mathbf{X I}\end{array}$ & $\begin{array}{l}23 / \mathbf{X} \\
23 / \mathbf{X} \\
26 / \mathbf{X} \\
30 / \mathbf{X} \\
31 / \mathbf{X}\end{array}$ & $\begin{array}{l}2.400 \\
2.050 \\
2.200 \\
2.200 \\
2.350\end{array}$ & $\begin{array}{l}3.5 \\
3.5 \\
3.5 \\
3.5 \\
3.5\end{array}$ & $\begin{array}{l}2.14 \\
2.40 \\
2.59 \\
1.72 \\
1.59\end{array}$ & $\begin{array}{l}61.0 \\
39.9 \\
73.4 \\
49.1 \\
45.3\end{array}$ & $\begin{array}{c}+, E \\
" 1 \\
" 1 \\
\prime \prime\end{array}$ \\
\hline \multicolumn{5}{|c|}{ 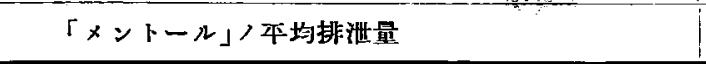 } & 2.09 & $\mathbf{5 3 . 7}$ & \\
\hline
\end{tabular}

第 3 表 (其) 2 )

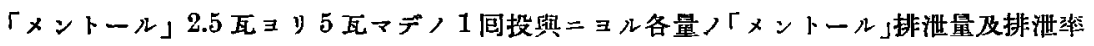

\begin{tabular}{|c|c|c|c|c|c|c|c|}
\hline $\begin{array}{l}\text { 家 } \\
\text { 鬼 } \\
\text { 列 } \\
\text { 數 }\end{array}$ & 賽驗期間 & $\begin{array}{l}\text { 投 } \\
\text { 盘 } \\
\text { 期 } \\
\text { 日 }\end{array}$ & 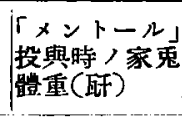 & 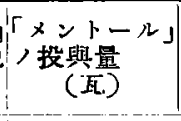 & 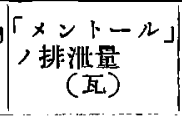 & 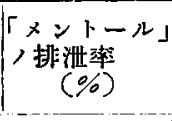 & 借 \\
\hline 16 & $22 / \mathrm{X}-26 / \mathrm{X}$ & $23 / \mathrm{X}$ & 2.250 & 4.0 & 3.18 & 79.6 & ナ \\
\hline 17 & $22 / \mathrm{X}-26 / \mathrm{X}$ & $23 / \mathbf{X}$ & 2.100 & 4.0 & 2.51 & 62.7 & "I \\
\hline 18 & $25 / \mathrm{X}-29 / \mathrm{X}$ & $26 / X$ & 2.350 & 4.0 & 1.50 & 37.6 & 11 \\
\hline 19 & $30 / \bar{X}-3 / \mathbf{X} \mathbf{I}$ & $31 / \mathbf{X}$ & 2.220 & 4.0 & 1.03 & 25.7 & $\prime \prime$ \\
\hline 20 & $1 / \mathbf{X I}-4 / \mathbf{X I}$ & $2 / \mathbf{X} \mathbf{I}$ & 2.100 & 4.0 & 1.04 & 25.9 & " \\
\hline \multicolumn{5}{|c|}{ 「メントール」ノ本均排洲量 } & $1.8 \bar{\jmath}$ & 46.3 & \\
\hline 21 & $21 / X-25 / X$ & $22 / \mathrm{X}$ & 2.100 & 4.5 & 1.04 & 23.1 & $\begin{array}{l}\text { 後肢ノ揤痹アリテ食 } \\
\text { 思不振トナル }\end{array}$ \\
\hline 22 & $22 / \mathrm{X}-26 / \mathrm{X}$ & $23 / X$ & 2.150 & 4.5 & 1.35 & 30.0 & 小 \\
\hline 23 & $28 / \mathbf{X}-1 / \mathbf{X} \mathbf{I}$ & $20 / \overline{\mathbf{X}}$ & 2.400 & 4.5 & 1.65 & 36.7 & 11 \\
\hline 24 & $31 / \bar{X}-4 / \overline{X I}$ & $1 / \mathbf{X I}$ & 2.800 & 4.5 & $1.3 n$ & 30.0 & 11 \\
\hline 25 & $1 / X I-5 / X I$ & $2 / X I$ & 2.000 & 4.5 & 1.89 & 42.1 & 18 \\
\hline \multicolumn{5}{|c|}{ 「メントール」ノ本均排使 } & 1.46 & 32.4 & \multirow{7}{*}{ 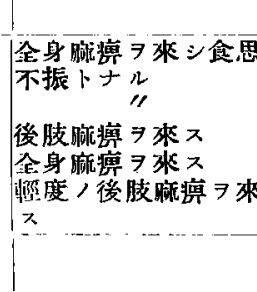 } \\
\hline 26 & $22 / X-26 / X$ & $23 / \mathrm{X}$ & 2.100 & 5.0 & 2.48 & 48.5 & \\
\hline 27 & $22 / \mathrm{X}-26 / \mathrm{X}$ & $23 / \mathrm{X}$ & 2.300 & 5.0 & 1.83 & 36.6 & \\
\hline 28 & $27 / X-31 / X$ & $28 / \mathbf{X}$ & 2.300 & 5.0 & 2.04 & 40.7 & \\
\hline 29 & $30 / X-3 / X I$ & $31 / \mathbf{X}$ & 2.200 & 5.0 & 1.49 & 29.8 & \\
\hline 30 & $1 / X I-4 / X I$ & $2 / \mathbf{X I}$ & 2.100 & 5.0 & 1.55 & 30.9 & \\
\hline \multicolumn{5}{|c|}{ 「メントール」ノ本均排湘量 } & 1.87 & 37.3 & \\
\hline
\end{tabular}


第 4 表

1 回 投 鼠 (本編第3表妇算出)

\begin{tabular}{|c|c|c|c|c|}
\hline \multirow{2}{*}{ 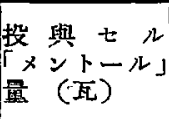 } & \multicolumn{2}{|c|}{$\begin{array}{c}\text { 「ダルクロン酸卜複合サ } \\
\text { レタルメントール」量 }\end{array}$} & \multicolumn{2}{|c|}{$\begin{array}{l}\text { 「グルクロン」酸ト複合サ } \\
\text { レザル「メントール」量. }\end{array}$} \\
\hline & 钼數 (瓦) & 百分等 $(\%)$ & 倪数(瓦) & 百分浲 ( $\%)$ \\
\hline $\begin{array}{l}2.0 \\
2.5 \\
3.0 \\
3.5 \\
4.0 \\
4.5 \\
5.0\end{array}$ & $\begin{array}{l}0.71 \\
1.12 \\
1.62 \\
1.88 \\
1.85 \\
1.46 \\
1.87\end{array}$ & $\begin{array}{l}35.7 \\
44.9 \\
54.0 \\
53.7 \\
46.3 \\
32.4 \\
37.2\end{array}$ & $\begin{array}{l}1.29 \\
1.38 \\
1.38 \\
1.62 \\
2.15 \\
3.04 \\
3.13\end{array}$ & $\begin{array}{l}64.3 \\
55.1 \\
46.0 \\
46.3 \\
53.7 \\
67.6 \\
62.7\end{array}$ \\
\hline
\end{tabular}

酸複合ノ最大量ト「メントール」 ノ中琵量トハ極メテ密接ノ關係 ニアルタ思ハシム。及「グルク ロン」酸ト複合サレザリシ「メ ントール」量算出スルニ，其 , 本均, 2.0 瓦投與二於テ 1.29 瓦, 2.5 瓦二於テ 1.38 瓦, 3.0 瓦 二於テ 1.38 瓦, 3.5 瓦二於テ 1.62

瓦 4.0 瓦以上二於テ 2.15 瓦, 4.5 瓦二於テ 3.04 瓦トナリ爱激二增加ス。双投與シタル「メントー ル量二對スル百分比モ 3.5 瓦ノ場合最モ少キヨ知ル，郎チ「グルクロン」酸複合ノ晌充分餘裕》 リト若フベキ $2.0 ， 2.5 ， 3.0$ 瓦投與／場合／複合サレザル「メントール」望八何レモ大體 1.30 瓦內

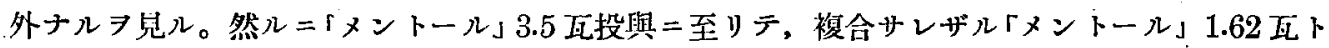
ナリソレ以上デハ向急激＝增加シ，且ツ動物モ 3.5 瓦以上ニテ中毒病狀 7 現ハスコト多キヨ以

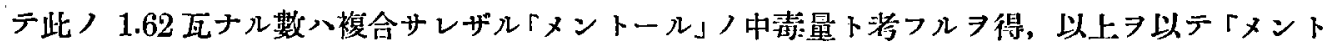
ール」3.5瓦附近ガ「グルクロン」酸複合上ヨリ見タル家鬼ノ「メントール」耐量ナル 4 表公热)

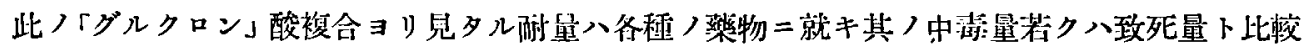
對照スレバ興味アラント考フ。

\section{第 4 節 一定間隔( 72時間)ヨ以テ「メントール」ヨ連續負荷セル 場合/生成「グルクロン」酸量}

1 同一量习反㫏七几場合

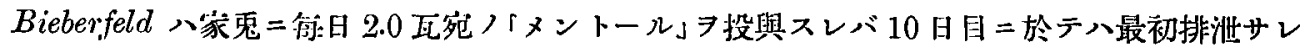

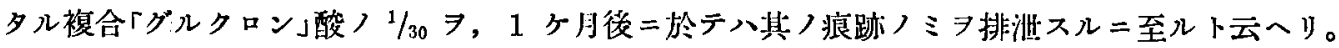

A. J. Quick 八彼自ラノ「グルクロン」酸定量法习使肘シテ之レヨ追試シタル結果「ヌントー

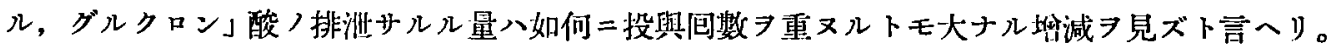

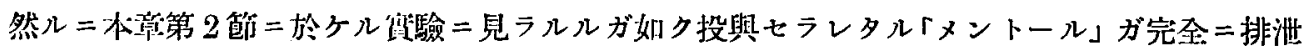
サルルハ24 時間以上 7 要スルガ故二, 若シ攸日「メントール」ヨ投與スルトキハ, 投與サレタ ル「メントール」ノ何體內二残存スル間二更二次ノ「メトール」ヨ投與スルコトトナル

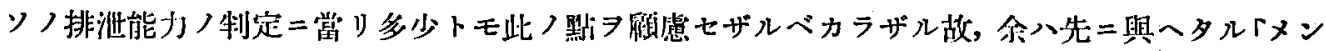

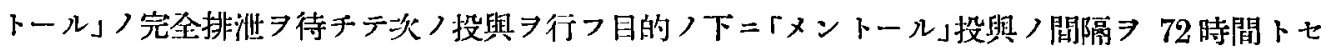
リ。郎チ「メントール」2.0瓦フ5 站ノ「オレーフ」油二溶解セシメ侣二加溫, 背部ノ皮下=72 時 間ノ間隔 $フ$ 以テ注射セリ。(符 5 表及ビ附圖參照) 


$$
\text { 歌 } 5 \text { 装 }
$$

(第1例)「メントール」2.0瓦

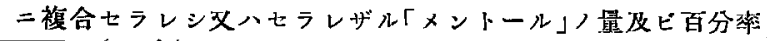

\begin{tabular}{|c|c|c|c|c|c|c|c|c|}
\hline \multicolumn{2}{|c|}{ 投 } & \multirow{2}{*}{ 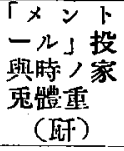 } & \multirow{2}{*}{ 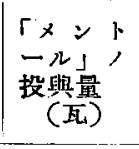 } & \multicolumn{2}{|c|}{ 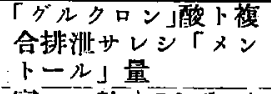 } & \multicolumn{2}{|c|}{$\begin{array}{l}\text { 「゙ルクロン酸ト䙡 } \\
\text { 合サレザル「メント } \\
\text { ール」量 }\end{array}$} & \multirow{2}{*}{$\begin{array}{c}\text { 储 考 } \\
\text { 中涽症狀 } \\
\text { ，有 無 }\end{array}$} \\
\hline 日/月 & 问数。 & & & $($ 瓦) & $\begin{array}{c}\text { 百 } \\
(\%)\end{array}$ & 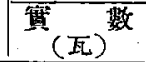 & $\begin{array}{c}\text { 百分苶 } \\
(\%)\end{array}$ & \\
\hline $5 /$ IV & 1 & 2.140 & 2.0 & 0.90 & 45.0 & 1.10 & 55.0 & \\
\hline $8 /$ IV & 2 & 2.156 & 2.0 & 0.42 & 21.0 & 1.58 & 79.0 & \\
\hline $11 / \mathrm{IV}$ & $\bar{x}$ & 2.170 & 2.0 & 0.60 & 30.0 & 1.40 & 70.0 & \\
\hline 44/IV & 4 & 2.160 & 2.0 & 0.89 & 14.5 & 1.71 & 85.5 & \\
\hline $17 /$ IV & 5 & 2.180 & 2.0 & 0.41 & 20.5 & 1.59 & 79.5 & \\
\hline $70 / \mathrm{IV}$ & 6 & 2.200 & 2.0 & 0.57 & 28.5 & 1.43 & 71.5 & ナシ \\
\hline $23 / I V$ & 7 & 2.190 & 2.0 & 0.72 & 86.0 & 1.28 & 64.0 & \\
\hline 26/IV & 8 & 2.200 & 2.0 & 0.72 & 36.0 & 1.28 & 64.0 & \\
\hline $20 / \mathrm{IV}$ & 9 & 2.200 & 2.0 & 0.68 & 31.5 & 1.37 & 68.5 & \\
\hline $2 / V$ & 10 & 2.250 & 2.0 & 0.56 & 28.0 & 1.4 .4 & 72.0 & \\
\hline 平 & 均 & & & $0 . \overline{5} 82$ & 29.1 & 1.418 & 71.9 & \\
\hline \multicolumn{9}{|c|}{ 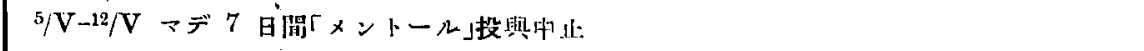 } \\
\hline $12 / V$ & 11 & 2.890 & 2.0 & 0.90 & $4 \overline{5} .0$ & 1.10 & $\mathbf{5 5 . 0}$ & \multirow{5}{*}{ ナシ } \\
\hline $15 / V$ & 12 & 2.290 & 2.0 & 0.60 & 32.5 & 1.95 & 67.5 & \\
\hline $18 / \mathrm{V}$ & 13 & 2.320 & 2.0 & 0.60 & 30.0 & 1.40 & 70.0 & \\
\hline $21 / \mathrm{V}$ & 14 & 2.350 & 2.0 & 0.94 & 47.0 & 1.06 & 53.0 & \\
\hline $24 / V$ & 15 & 2.400 & 2.0 & 0.71 & 35.5 & 1.29 & 64.5 & \\
\hline 平 & 均 & & $-\cdot-$ & 0.76 & 34.0 & 1.24 & 62.0 & \\
\hline 中止 & & & 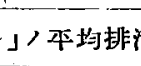 & & & $9.17 \mathrm{~S}$ 瓦 & & \\
\hline
\end{tabular}

$$
\text { 第 } 5 \text { 表 (其， } 2 \text { ) }
$$

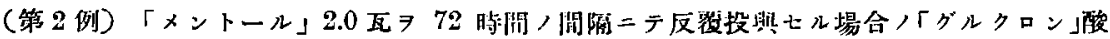

\begin{tabular}{|c|c|c|c|c|c|c|c|c|}
\hline \multicolumn{2}{|c|}{ 投 } & \multirow{2}{*}{ 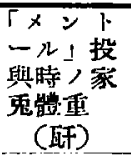 } & \multirow{2}{*}{ 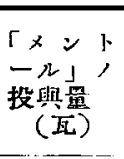 } & \multicolumn{2}{|c|}{ 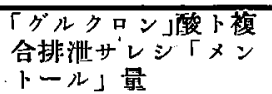 } & \multicolumn{2}{|c|}{$\begin{array}{l}\text { 「グルクロン酸ト複 } \\
\text { 合サレザル「メント } \\
\text { ール」量 }\end{array}$} & \multirow{2}{*}{ 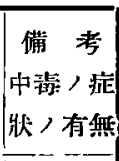 } \\
\hline 日/月 & 问數 & & & 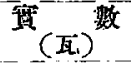 & $\begin{array}{l}\text { 百 } \\
(0) 0)\end{array}$ & $(\text { 互 })^{\text {列 }}$ & $\begin{array}{c}\text { 百 } 8 \text { 分得 } \\
(\%)\end{array}$ & \\
\hline $\begin{array}{l}5 / \mathrm{IV} \\
8 / \mathrm{IV} \\
11 / \mathrm{IV} \\
14 / \mathrm{IV} \\
17 / \mathrm{IV} \\
20 / \mathrm{IV} \\
23 / \mathrm{IV} \\
26 / \mathrm{IV} \\
29 / \mathrm{IV} \\
2 / \mathrm{V}\end{array}$ & $\begin{array}{r}1 \\
2 \\
3 \\
4 \\
5 \\
6 \\
7 \\
8 \\
9 \\
10\end{array}$ & $\begin{array}{l}2.140 \\
2.100 \\
2.120 \\
2.150 . \\
2.155 \\
2.180 \\
2.170 \\
2.200 \\
2.220 \\
2.250\end{array}$ & $\begin{array}{l}2.0 \\
2.0 \\
2.0 \\
2.0 \\
2.0 \\
2.0 \\
2.0 \\
2.0 \\
2.0 \\
2.0\end{array}$ & $\begin{array}{l}0.59 \\
0.52 \\
0.25 \\
0.25 \\
0.26 \\
0.20 \\
0.64 \\
0.49 \\
0.50 \\
0.22\end{array}$ & $\begin{array}{l}29.5 \\
26.0 \\
14.0 \\
12.5 \\
13.0 \\
10.0 \\
32.0 \\
24.5 \\
25.0 \\
11.0\end{array}$ & $\begin{array}{l}1.41 \\
1.48 \\
1.72 \\
1.75 \\
1.74 \\
1.80 \\
1.36 \\
1.51 \\
1.50 \\
1.78\end{array}$ & $\begin{array}{l}70.5 \\
74.0 \\
86.0 \\
87.5 \\
87.0 \\
90.0 \\
67.0 \\
75.5 \\
75.0 \\
89.0\end{array}$ & $!$ \\
\hline 本 & 均 & & & 0.395 & 19.75 & 1.605 & 80.15 & \\
\hline \multicolumn{9}{|c|}{$5 / \mathrm{V}$-12/V マデ 7 日閒「メントール」投與中止 } \\
\hline $\begin{array}{l}12 / \mathrm{V} \\
15 / \mathrm{V} \\
118 / \mathrm{V} \\
21 / \mathrm{V}\end{array}$ & $\begin{array}{l}11 \\
12 \\
13 \\
14\end{array}$ & $\begin{array}{l}2.280 \\
2.260 \\
2.275 \\
2.810\end{array}$ & $\begin{array}{l}2.0 \\
2.0 \\
2.0 \\
2.0\end{array}$ & $\begin{array}{l}0.73 \\
0.60 \\
0.91 \\
0.47\end{array}$ & $\begin{array}{l}36.5 \\
30.0 \\
45.5 \\
23.5\end{array}$ & $\begin{array}{l}1.27 \\
1.40 \\
1.09 \\
1.53\end{array}$ & $\begin{array}{l}63.5 \\
70.0 \\
54.5 \\
76.5\end{array}$ & \\
\hline
\end{tabular}

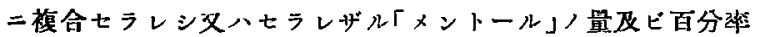




\begin{tabular}{|c|c|c|c|c|c|c|c|}
\hline \multirow[t]{2}{*}{$24 / V$} & 15 & 2.330 & 2.0 & 0.71 & 35.5 & 1.29 & 64.5 \\
\hline & & & & 0.684 & 34.2 & 1.316 & 65.8 \\
\hline
\end{tabular}

第 5 表 (其, 3 )

(第3 例)「メントール」 2.0 瓦 72 時間ノ閒隔二テ反醷投與セル場合ノ「グルクロン」酸 二複合せラレシタハセラレザル「メントール」ノ量及ビ百分無

\begin{tabular}{|c|c|c|c|c|c|c|c|c|}
\hline \multicolumn{2}{|c|}{ 投 } & \multirow{2}{*}{ 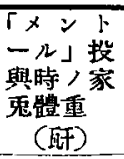 } & \multirow{2}{*}{$\begin{array}{c}\Gamma x ン \Gamma \\
-\pi j, \\
\text { 投與時 } \\
\text { (瓦) }\end{array}$} & \multicolumn{2}{|c|}{ 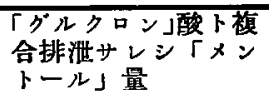 } & \multicolumn{2}{|c|}{ 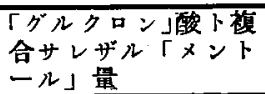 } & \multirow{2}{*}{$\begin{array}{c}\text { 備 考 } \\
\text { 中求 / 症 } \\
\text { 狀 / 有無 }\end{array}$} \\
\hline 日月 & 回數 & & & $(\text { 瓦 })^{\text {數 }}$ & 百分箱 & 寛 $($ 桼) & $\begin{array}{l}\text { 百分筸 } \\
(\%)\end{array}$ & \\
\hline $5 / \mathrm{IV}$ & 1 & 2.200 & 2.0 & 0.46 & 23.0 & 1.54 & 77.0 & \\
\hline 8/IV & 2 & 2.200 & 2.0 & 0.41 & 20.5 & 1.59 & 79.5 & \\
\hline $11 / \mathrm{IV}$ & 3 & 2.190 & 2.0 & 0.31 & 15.5 & 1.69 & 84.5 & \\
\hline $14 / 1 \mathrm{IV}$ & 4 & 2.210 & 2.0 & 0.25 & 12.5 & 1.75 & 87.5 & \\
\hline $17 / \mathrm{IV}$ & 5 & 2.220 & 2.0 & 0.27 & 13.5 & 1.73 & 86.5 & \\
\hline $2_{0}^{2} / \mathrm{IV}$ & 6 & 2.210 & 2.0 & 0.26 & 13.0 & 1.74 & 87.0 & \\
\hline $23 /$ IV & 7 & 2.220 & 2.0 & 0.24 & 12.0 & 1.76 & 88.0 & \\
\hline $26 /$ IV & 8 & 2.250 & 3.0 & 0.24 & 12.0 & 1.76 & 88.0 & \\
\hline $20 / \mathrm{IV}$ & 9 & 2.245 & 2.0 & 0.42 & 21.0 & 1.58 & 79.0 & \\
\hline $2 / \mathrm{V}$ & 10 & 2.270 & 2.0 & 0.29 & 14.5 & 1.71 & 85.5 & \\
\hline 平 & 均 & & & 0.315 & 15.75 & 1.685 & 84.25 & \\
\hline \multicolumn{9}{|c|}{$5 / \mathrm{V}-12 / \mathrm{V}$ マデ7日閌「メントール」投與中止 } \\
\hline $12 / \mathrm{V}$ & 11 & 2.290 & 2.0 & 0.85 & 42.5 & 1.15 & 57.5 & \\
\hline $15 / \mathrm{V}$ & 12 & 3.300 & 2.0 & 0.49 & 24.5 & 1.51 & 75.5 & \\
\hline $18 / \mathrm{V}$ & 13 & 2.310 & 2.0 & 0.79 & 38.0 & 1.21 & 62.0 & \\
\hline $21 / V$ & 14 & 2.320 & 2.0 & 0.56 & 28.0 & 1.44 & 720 & \\
\hline $24 / \mathrm{V}$ & 15 & 2.350 & 2.0 & 0.80 & 40.0 & 1.20 & 60.0 & \\
\hline 平 & 均 & & & 0.698 & 34.6 & 1.302 & 65.4 & \\
\hline \multicolumn{9}{|c|}{ 中止前後ノ「メントール」ノ本均排泄，捪減 $\begin{array}{l}0.698-0.315=0.383 \\
34.6-15.75=18.85 \%\end{array}($ 努) } \\
\hline
\end{tabular}

第 5 表 (其, 4 )

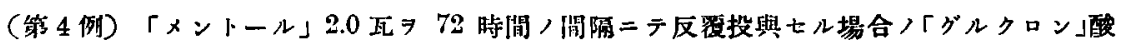
二襩合セラレシメハ七ラレザル「メントール」ノ量及ビ百分率

\begin{tabular}{|c|c|c|c|c|c|c|c|c|}
\hline \multicolumn{2}{|c|}{ 投 } & \multirow{2}{*}{$\begin{array}{l}\Gamma x ン ト \\
\text { 一ル」投 } \\
\text { 與時,家 } \\
\text { 鬼蹬重 } \\
\text { (瓦) }\end{array}$} & \multirow{2}{*}{ 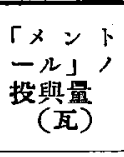 } & \multicolumn{2}{|c|}{ 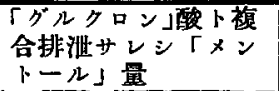 } & \multicolumn{2}{|c|}{ 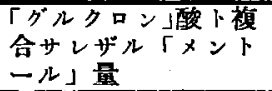 } & \multirow{2}{*}{ 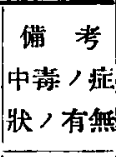 } \\
\hline 日月 & 闵數 & & & $($ 桼) & $\begin{array}{c}\text { 百 }(\%) \\
(\%)\end{array}$ & $(\text { 瓦 })^{\text {数 }}$ & $\begin{array}{c}\text { 百分率 } \\
(\%)\end{array}$ & \\
\hline $8 / \mathrm{V}$ & 1 & 2.100 & 2.0 & 0.72 & 36.0 & 1.28 & 64.0 & \\
\hline $11 / \mathrm{V}$ & 8 & 2.180 & 2.0 & 0.79 & 39.5 & 1.21 & 60.5 & \\
\hline $14 / \mathrm{V}$ & 3 & 2.250 & 2.0 & 0.65 & 32.5 & 1.35 & 67.5 & \\
\hline $17 / \mathrm{V}$ & 4 & 2.320 & 2.0 & 0.92 & 46.0 & 1.08 & 54.0 & \\
\hline $20 / \mathrm{V}$ & a & 2.390 & 2.0 & 0.79 & 39.5 & 1.21 & 60.5 & \\
\hline $23 / V$ & 6 & 2.410 & 2.0 & 0.79 & 39.5 & 1.21 & 60.5 & \\
\hline $26 / V$ & 7 & 2.400 & 2.0 & 0.80 & 40.0 & 1.20 & 60.0 & \\
\hline $20 / \mathrm{V}$ & 8 & 2.390 & 2.0 & 0.87 & 43.5 & 1.13 & 56.5 & \\
\hline $1 / \mathrm{VI}$ & 9 & 2.420 & 2.0 & 0.73 & 36.5 & 1.27 & 63.5 & \\
\hline $4 / \mathrm{VI}$ & 10 & 2.450 & 2.0 & 0.88 & 44.0 & 1.12 & 56.0 & \\
\hline 平 & 均 & & & 0.794 & 39.7 & 1.206 & 60.3 & \\
\hline
\end{tabular}




\begin{tabular}{|c|c|c|c|c|c|c|c|c|}
\hline $\begin{array}{l}14 / \mathrm{VI} \\
27 / \mathrm{VI} \\
10 / \mathrm{VI} \\
23 / \mathrm{VI} \\
26 / \mathrm{VI}\end{array}$ & $\begin{array}{l}11 \\
12 \\
13 \\
14 \\
15\end{array}$ & $\begin{array}{l}2.490 \\
2.450 \\
2.480 \\
2.560 \\
2.600\end{array}$ & $\begin{array}{l}2.0 \\
2.0 \\
2.0 \\
2.0 \\
2.0\end{array}$ & $\begin{array}{l}1.02 \\
1.19 \\
1.21 \\
0.93 \\
0.95\end{array}$ & $\begin{array}{l}51.0 \\
55.5 \\
60.5 \\
46.5 \\
47.5\end{array}$ & $\begin{array}{l}0.98 \\
0.81 \\
0.79 \\
1.07 \\
1.05\end{array}$ & $\begin{array}{l}49.0 \\
44.5 \\
39.5 \\
53.5 \\
52.5\end{array}$ & ナシ \\
\hline 平 & 均 & & & 1.06 & 52.2 & 0.98 & 47.8 & \\
\hline
\end{tabular}

第 5 装附孀

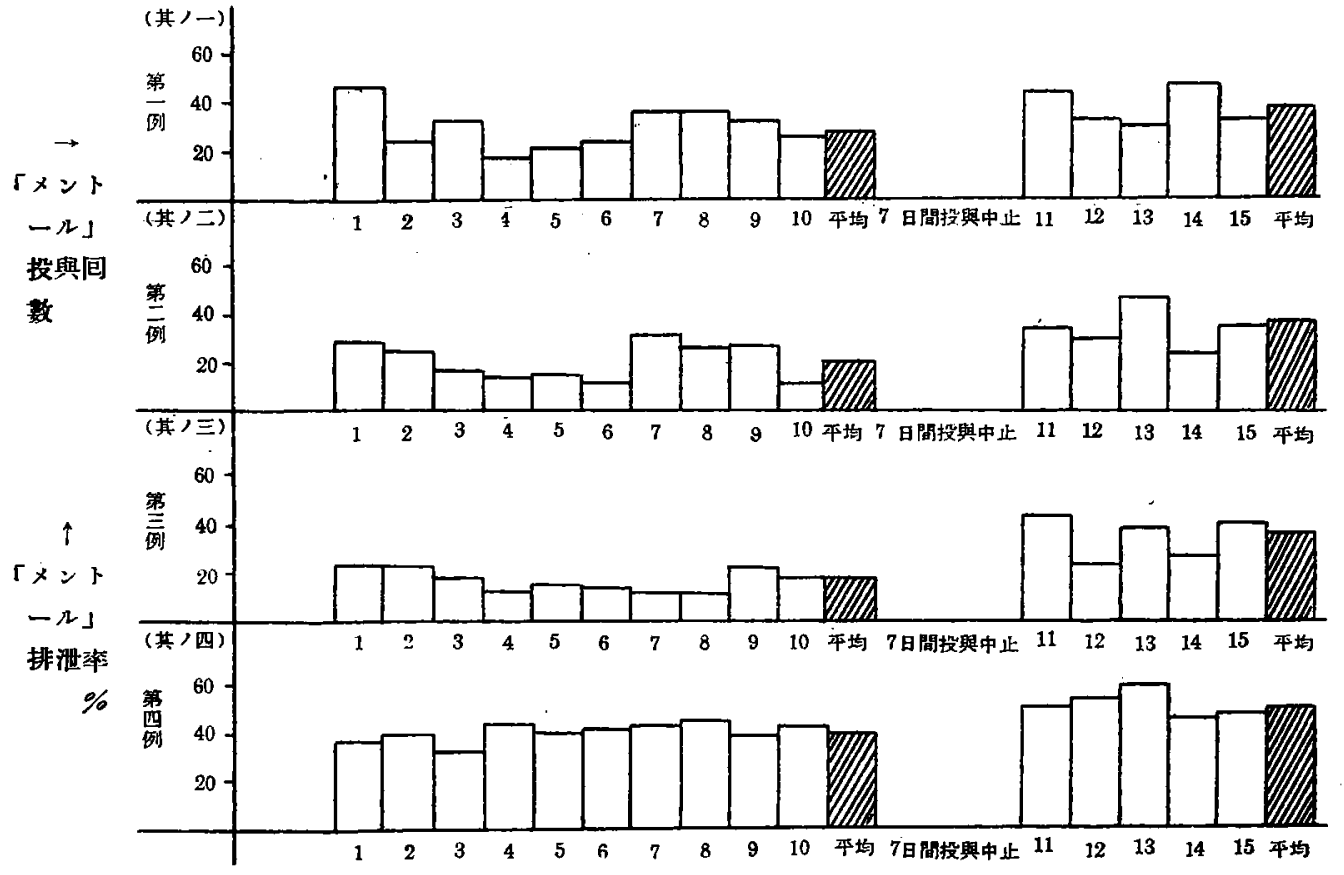

今 4 例 =就キ其ノ成績 7 見ル二, 內 3 例八第 2 回以後ノ「グルクロン」酸椱合「メントール」量 八第1回ノ場合ヨリ一般二僅カノ減量

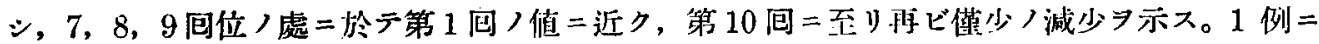

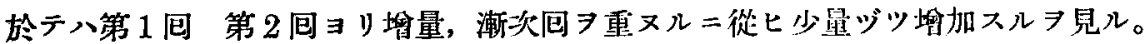

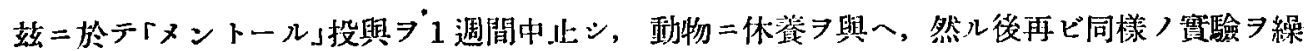
リ这セリ。然ル = 4例共休止後第 1 回ノ投與二於テ「グルクロン」酸䙉合「メントール」量ハ休止

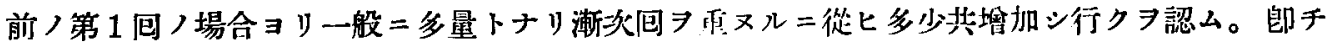
2 正前啳, 家鬼 5,6回マデニ示ス「グルクロン」酸複合「メントール」量ノ減少八生體ノ「グルクロン」酸生成能力 フ减弱 7 示シ， 7,8 回二於テ秒習量 
ラン。份 1 例ト八雖モ最初ヨリ渐次间 ヨ重ヌルニ從ヒ「グルクロン」酸混合「メントール」量ノ增 加七ルモノアルハ「メントール」2.0瓦投與 772 時間ノ間隔 7 以テ行フ場合，家鬼體內「グルク

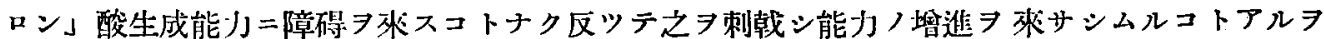

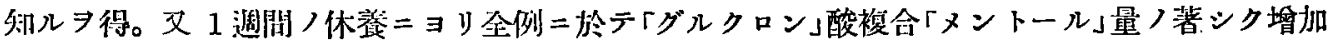

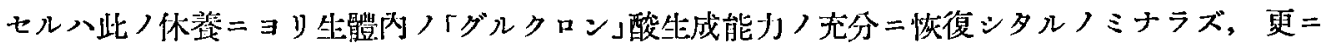
平常以上充進セルラ亦スモノナリ。

\section{2 漸次負荷量 $\exists$ 增加セル場合}

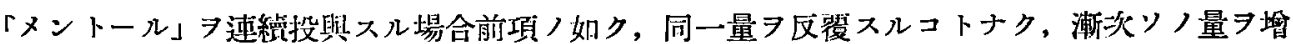
加スレバ如何ナランカ。

$$
\text { 第 } 6 \text { 表 (其, } 1 \text { ) }
$$

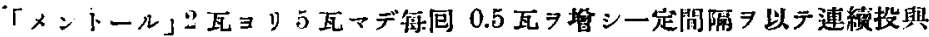

セル場合ノ各何二於ケル「メントール」排泄筷

\begin{tabular}{|c|c|c|c|c|c|c|c|c|}
\hline $\begin{array}{l}\text { 家 } \\
\text { 兔 } \\
\text { 例 } \\
\text { 数 }\end{array}$ & $\begin{array}{l}\text { 憲 } \\
\text { 酸 } \\
\text { 期 } \\
\text { 間 }\end{array}$ & 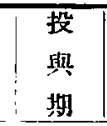 & $\begin{array}{l}\text { 投 } \\
\text { 與 } \\
\text { 间 } \\
\text { 数 } \\
\end{array}$ & 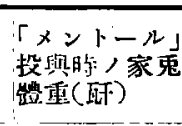 & 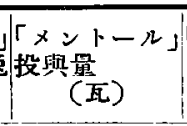 & 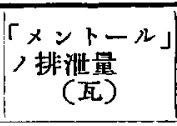 & $\left|\begin{array}{c}\Gamma x+ト ー ル 」 \\
\text { 排泄焦 } \\
(\%)\end{array}\right|$ & $\begin{array}{c}\text { 備 考 } \\
\text { (中海症狀，有無) }\end{array}$ \\
\hline I & $\begin{array}{c}\text { 8/VII } \\
\downarrow \\
30 / \mathrm{VII}\end{array}$ & 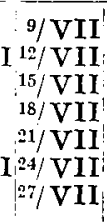 & $\begin{array}{l}1 \\
2 \\
3 \\
4 \\
5 \\
6 \\
7\end{array}$ & $\begin{array}{l}2.370 \\
2.350 \\
2.280 \\
2.200 \\
2.120 \\
2.120 \\
2.040\end{array}$ & $\begin{array}{l}2.0 \\
2.5 \\
3.0 \\
3.5 \\
4.0 \\
4.5 \\
5.0\end{array}$ & $\begin{array}{l}0.67 \\
0.84 \\
0.99 \\
2.14 \\
2.24 \\
2.14 \\
1.71\end{array}$ & $\begin{array}{l}33.3 \\
33.4 \\
33.0 \\
64.0 \\
56.0 \\
47.5 \\
\mathbf{3 4 . 1}\end{array}$ & 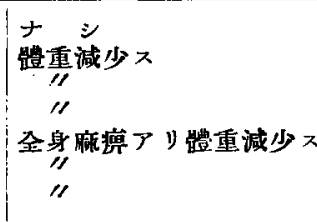 \\
\hline II & $\downarrow_{30 / \text { VII }}^{8 / \text { VII }}$ & $\begin{array}{l}9 / \mathrm{VII} \\
12 / \mathrm{VII} \\
15 / \mathrm{VII} \\
18 / \mathrm{VII} \\
21 / \mathrm{VII} \\
\mathbf{I}^{24} / \mathrm{VII} \\
27 / \mathrm{VII}\end{array}$ & $\begin{array}{l}1 \\
2 \\
3 \\
4 \\
5 \\
6 \\
7\end{array}$ & $\begin{array}{l}2.100 \\
2.050 \\
1.950 \\
1.870 \\
1.750 \\
1.630 \\
1.500\end{array}$ & $\begin{array}{l}2.0 \\
2.5 \\
3.0 \\
3.5 \\
4.0 \\
4.5 \\
5.0\end{array}$ & $\begin{array}{l}0.72 \\
1.08 \\
1.29 \\
2.63 \\
2.75 \\
2.50 \\
2.16\end{array}$ & $\begin{array}{l}36.0 \\
43.1 \\
43.1 \\
75.2 \\
68.7 \\
55.5 \\
43.2\end{array}$ & 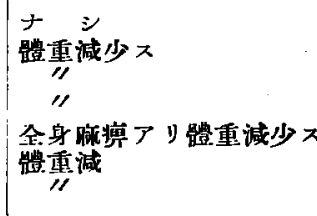 \\
\hline III & $\left.\right|_{7 / X I 1} ^{15 / X I}$ & $\begin{array}{l}16 / \mathbf{X I} \\
19 / \mathbf{X I} \\
22 / \mathbf{X I} \\
25 / \mathbf{X I} \\
28 / \mathbf{X I} \\
1 / \mathbf{X} 11 \\
4 / \mathbf{X I I}\end{array}$ & $\begin{array}{l}1 \\
\mathbf{2} \\
: 3 \\
4 \\
5 \\
6 \\
7\end{array}$ & $\begin{array}{l}2.100 \\
1.900 \\
1.820 \\
1.750 \\
1.620 \\
1.610 \\
1.550\end{array}$ & $\begin{array}{l}2.0 \\
2.5 \\
3.0 \\
3.5 \\
4.0 \\
4.5 \\
5.0\end{array}$ & $\begin{array}{l}0.80 \\
1.60 \\
2.18 \\
1.59 \\
2.28 \\
2.10 \\
1.80\end{array}$ & $\begin{array}{l}40.2 \\
63.9 \\
72.5 \\
45.5 \\
55.7 \\
46.7 \\
33.9\end{array}$ & 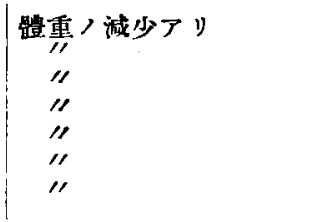 \\
\hline IV & $\overbrace{1 / 1}^{10}$ & $\begin{array}{l}11 / \text { XII } \\
\text { I } 11 / \text { XII } \\
17 / \text { XII } \\
20 / \text { XII } \\
23 / \text { XII } \\
26 / \text { XII } \\
29 / \text { XII }\end{array}$ & $\begin{array}{l}1 \\
2 \\
: 3 \\
4 \\
5 \\
6 \\
7\end{array}$ & $\begin{array}{l}2.350 \\
2.150 \\
2.200 \\
2.000 \\
2.100 \\
2.000 \\
2.000\end{array}$ & $\begin{array}{l}2.0 \\
2.5 \\
3.0 \\
3.5 \\
4.0 \\
4.5 \\
5.0\end{array}$ & $\begin{array}{l}0.71 \\
1.57 \\
2.20 \\
2.78 \\
2.22 \\
2.00 \\
2.06\end{array}$ & $\begin{array}{l}35.3 \\
62.7 \\
73.3 \\
79.4 \\
55.4 \\
44.4 \\
41.1\end{array}$ & 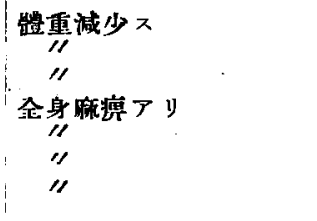 \\
\hline $\mathrm{V}$ & $\underset{27 / 1}{\downarrow}$ & $\begin{array}{l}6 / \mathbf{I} \\
9 / \mathbf{I} \\
12 / \mathbf{I} \\
15 / \mathbf{I} \\
18 / \mathbf{I} \\
21 / \mathbf{I} \\
21 / \mathbf{I}\end{array}$ & $\begin{array}{l}1 \\
2 \\
3 \\
4 \\
5 \\
6 \\
7\end{array}$ & $\begin{array}{l}2.250 \\
2.180 \\
2.120 \\
2.100 \\
2.100 \\
2.100 \\
2.100\end{array}$ & $\begin{array}{l}2.0 \\
2.5 \\
3.0 \\
3.5 \\
4.0 \\
4.5 \\
5.0\end{array}$ & $\begin{array}{l}0.90 \\
1.64 \\
2.15 \\
1.77 \\
2.30 \\
2.12 \\
2.29\end{array}$ & $\begin{array}{l}45.0 \\
65.6 \\
71.6 \\
50.7 \\
57.6 \\
47.2 \\
45.7\end{array}$ & 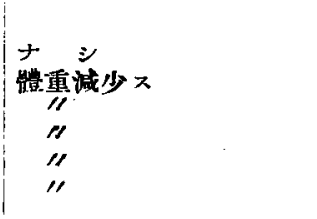 \\
\hline
\end{tabular}




$$
\text { 第 } 6 \text { 表 (其, } 2 \text { ) }
$$

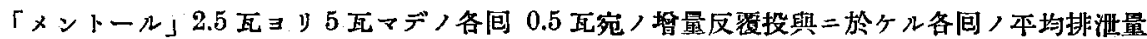

\begin{tabular}{|c|c|c|c|c|c|c|c|}
\hline $\begin{array}{l}\text { 家 } \\
\text { 蒐 } \\
\text { 例 } \\
\text { 數 }\end{array}$ & $\begin{array}{c}\text { 「メントール」 } \\
\text { 投與量 } \\
\text { (鳬) }\end{array}$ & 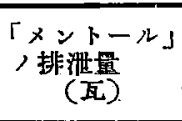 & $\underset{\substack{\text { 「排浛率 } \\
(\%)}}{ }$ & $\begin{array}{l}\text { 家 } \\
\text { 鬼 } \\
\text { 例 } \\
\text { 數 }\end{array}$ & 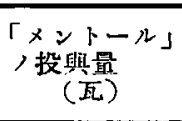 & $\begin{array}{c}\text { 「メントール」 } \\
\text { ノ排泄量 } \\
\text { (瓦) }\end{array}$ & $\begin{array}{c}\text { 「メンール」 } \\
\text { 排浀篗 } \\
(\%)\end{array}$ \\
\hline $\begin{array}{l}1 \\
2 \\
3 \\
4 \\
5\end{array}$ & $\begin{array}{ll}2.5 & \\
2.5 & \\
2.5 & \\
2.5 & \\
2.5 & \\
& \text { 均 }\end{array}$ & $\begin{array}{l}0.84 \\
1.08 \\
1.60 \\
1.57 \\
1.64 \\
1.34\end{array}$ & $\begin{array}{l}33.4 \\
43.1 \\
63.9 \\
62.7 \\
65.6 \\
54.0\end{array}$ & $\begin{array}{l}1 \\
2 \\
3 \\
4 \\
5\end{array}$ & $\begin{array}{l}4.0 \\
4.0 \\
4.0 \\
4.0 \\
4.0\end{array}$ & $\begin{array}{l}2.24 \\
2.75 \\
2.23 \\
2.22 \\
2.30 \\
2.35\end{array}$ & $\begin{array}{l}56.0 \\
68.7 \\
55.7 \\
55.4 \\
57.6 \\
58.7\end{array}$ \\
\hline $\begin{array}{l}1 \\
2 \\
3 \\
4 \\
5\end{array}$ & $\begin{array}{l}\mathbf{3 . 0} \\
3.0 \\
\mathbf{3 . 0} \\
\mathbf{3 . 0} \\
\mathbf{3 . 0} \\
\end{array}$ & $\begin{array}{l}0.99 \\
1.29 \\
2.18 \\
2.20 \\
2.15 \\
1.76\end{array}$ & $\begin{array}{l}33.0 \\
43.1 \\
72.5 \\
73.3 \\
71.6 \\
58.9\end{array}$ & \begin{tabular}{l|}
1 \\
2 \\
3 \\
4 \\
5 \\
平
\end{tabular} & $\begin{array}{l}4.5 \\
4.5 \\
4.5 \\
4.5 \\
4.5\end{array}$ & $\begin{array}{l}2.14 \\
2.50 \\
2.10 \\
2.00 \\
2.12 \\
2.17\end{array}$ & $\begin{array}{l}47.5 \\
55.5 \\
46.7 \\
44.4 \\
47.2 \\
48.3\end{array}$ \\
\hline \begin{tabular}{l|}
1 \\
2 \\
3 \\
4 \\
5 \\
平
\end{tabular} & $\begin{array}{ll}3.5 & \\
3.5 & \\
3.5 & \\
3.5 & \\
3.5 & \\
& \text { 均 }\end{array}$ & $\begin{array}{l}2.24 \\
2.63 \\
1.59 \\
2.78 \\
1.77 \\
2.20\end{array}$ & $\begin{array}{r}64.0 \\
75.2 \\
45.5 \\
79.4 \\
50.7 \\
63.0\end{array}$ & \begin{tabular}{l|}
1 \\
2 \\
3 \\
4 \\
5
\end{tabular} & $\begin{array}{l}5.0 \\
5.0 \\
5.0 \\
5.0 \\
5.0\end{array}$ & $\begin{array}{l}1.71 \\
2.16 \\
1.70 \\
2.06 \\
2.29 \\
1.98\end{array}$ & $\begin{array}{l}34.1 \\
43.2 \\
33.9 \\
41.1 \\
45.7 \\
40.2\end{array}$ \\
\hline
\end{tabular}

第 7 表

速 縝 投 與 (本編第 6 表 $\equiv$ y算出)

\begin{tabular}{|c|c|c|c|c|}
\hline \multirow{2}{*}{ 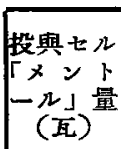 } & \multicolumn{2}{|c|}{$\begin{array}{l}\text { 「グルクロン」酸ト藉 } \\
\text { 合サレタル「メント } \\
\text { ル」量 }\end{array}$} & \multicolumn{2}{|c|}{$\begin{array}{l}\text { 「ゲルクロン」ト椱合 } \\
\text { サレザル「メントー } \\
\text { ル」 }\end{array}$} \\
\hline & (瓦) & $\begin{array}{c}\text { 百 分 秉 } \\
(\%)\end{array}$ & ${ }^{1}$ (不) & $\begin{array}{c}\text { 百分 } \\
(\%)\end{array}$ \\
\hline 2.0 & 0.76 & 38.0 & 1.24 & 62.0 \\
\hline 2.5 & 1.35 & 54.0 & 1.15 & 46.0 \\
\hline 2.0 & 1.77 & 58.9 & 1.23 & 41.0 \\
\hline 3.5 & 2.21 & 63.0 & 1.30 & 37.0 \\
\hline 4.0 & 2.35 & 53.7 & 1.65 & 41.3 \\
\hline 4.5 & 2.17 & 48.3 & 2.33 & 51.7 \\
\hline 5.0 & 2.01 & 40.2 & 3.00 & 59.8 \\
\hline
\end{tabular}

郎チ第 7 表二於デ見ルガ如ク,「グルクロ ン」酸ト複合サレテ排泄セラルル「メント 一ル」量八第 5 包目ノ投與郎千 4.0 瓦ノ場 合 2.35 瓦 ベ,反テソノ複命量ハ減少ス。投與量ガ少ナ キ場合二於テモ文其ノ複合量少ナキ故，此 ２.35正 7 以テ漸次負荷量 7 增加七ル場合 つ家鬼 1 日ノ「グルクロン」酸生成量ノ極限 トス。又「グルクロン小酸ト複命セラレザル

「メントール」量 7 算出スル

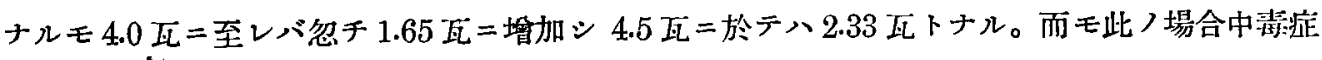
狀ノ現ハルルハ第 6 表(其ノ一) =示スガ如ク, 3.5 正入ハ 4.0 瓦投與ノ場合ナル

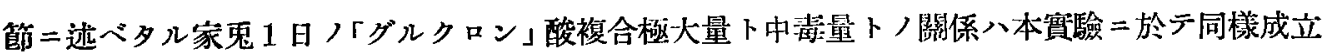
スルモノナリ。致第 3 節二於デグルクロン」酸ト複合サレザルトメントール」中毒量トシテ 1.62 瓦ナル數 7 得タル 及以テ余ノ提唱スル「グルクロン」酸ト複合セラレザル「メントール」ノ中毒量ナルモノノ存スル

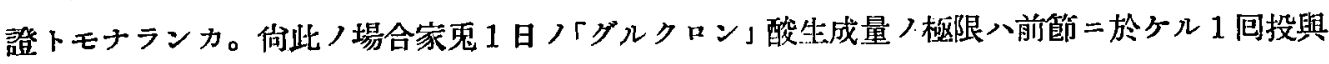

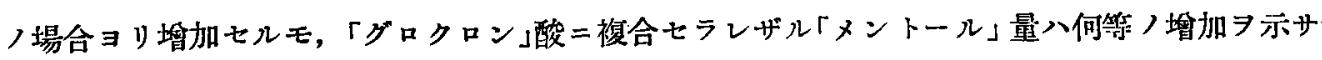


ズシテ,等シク 1.65 瓦二卖シタルト動物ハ中青症狀ヨ現ハスコトヨリ考フレバ,「メントール」 二對スル動物ノ習慣性トモ稱スベキモつ八主トシテ複合「グルクロン」酸量ノ增加＝ヨリ得ルモ ノナルコトラ想像シ得。但シ尿中排淮複合「グルクロン」酸量ハ必ズシモ生體內生成複合「グル

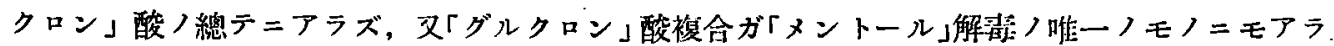

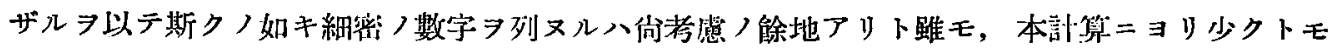
事賽ノ片鱗ヨ塞知シ得ベシト信ズ。

\section{第 5 章 總括及ビ考察}

（1）尿中ノ「グルクロン」酸定量法ヨ扫ヒテ糖類ノ生體內「グルクロン」酸生成二及ス影響 系スル $=$ 當リ，尿中 $=$ 「グルクロン」酸ト共二䌅類つ共存スル場合ハ「グルクロン」酸/定量二少 ナカラズ困難ヨ感ズルモノナリ。此ノ不便ヨモ免ルルタメQuickノ「メントール，グルクロン」 酸定量法郎チ「メントール,グルクロン」酸ガ「エーテル」＝溶解性デアリ,糖類ガソレ二不溶性ナ

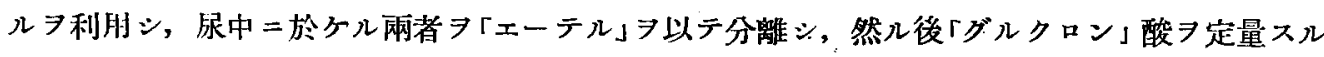

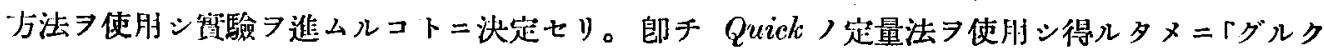

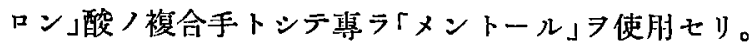

（2）「メントール」ヨ皮下゙=注射七ル場合尿中二複合「グルクロン」酸トシテ排泄サルル場合，

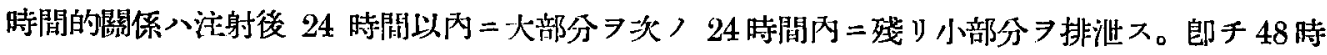
閒以內 $=$ 排沚シ終ル。

（3）２证前後ノ家鬼 1 日ノ「グルクロン」酸複合「メントール」排泄量ノ最大八 3.5 瓦投與時， 1.87 瓦ニシテ，ソノ投與「メントール」量ガ 3.5 瓦以下=テモ以上ニテモ其ノ排泄量ハ減少ス。

（4）余八「グルクロン」酸ト複合サレザル「メントール」ノ毒量ナルモノ 「グルクロン」酸複合ノ倘餘裕アリト考フベキ $2.0,2.5,3.0$ 瓦投與ノ場合ノ複合サレザル「メン トール」量八何レモ大體 1.30 瓦前後ナルモ 3.5 瓦投與二至り 1.62 瓦二上昇シ 4.0 瓦及ビりレ以上 ニテハ份其ノ增量著シク且” 3.5 瓦ア投與シタルトキハ一般二中毒症狀 7 呈スル シ以テ「グルクロン」酸ト複命将レザル「メントール」中瑇量トス。

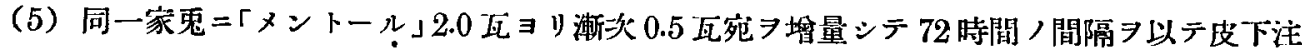
射スル =前項ノ「グルクロン」酸複命「メントール」ノ最大量 1.87 瓦入增加シテ 2.35 瓦トナル。郎

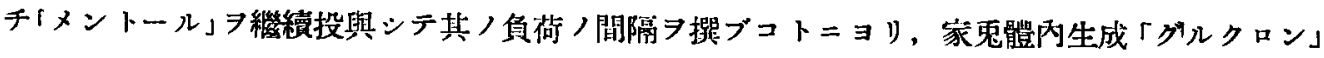
酸ノ最大量习增加セシメ得ルコトア知ル。

（6）「グルクロン」酸ト複合サレザル「メントール」ノ中毒量ハ「メントール」負荷可繼續的二行 ヒ「グルクロン」酸複合「メントール」量ノ增加セル場合ト雖モ增加セザルラ認ム。郎チ 1 回投與

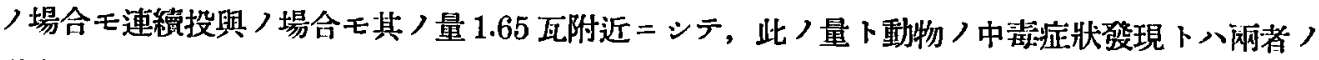
場合相一致ス。依ツテ「メントール」對スル家東ノ習慣性トモ稱スベキモノ八主トシテ複合「グ ルクロン」酸生成ノ增加ニョリ得ルモノニシテ,「グルクロン」酸ト複合サレザル「メントール」 量二對シテハ習慣性ヨ示サザルモノナリト想像シ得。 


\section{第 2 編 生體內「メントール,ダルクロン」酸生成ノ單糖類 \\ ニョル影響二就テ}

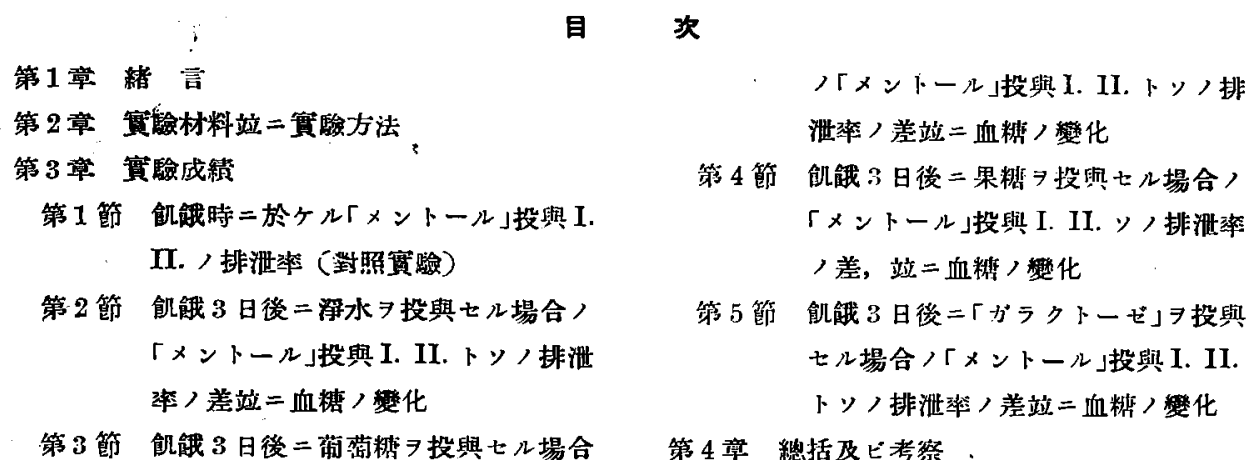

\section{第 1 章 緒言}

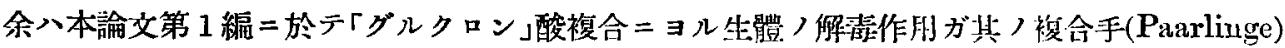

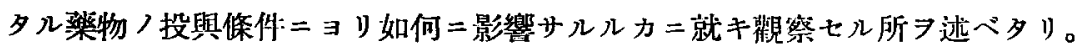

次デ余入本編＝於テ其ノ化學構造式上「グルクロン」酸ト八極メテョク類似シ，且ツ生體つエ

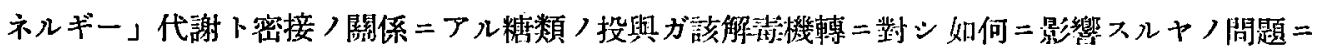
就論及セントス。

從來，糖類投與 生體=及ス影響二關スル先人ノ賽驗報告ハ少ナカラザレドモ，ソノ多數八

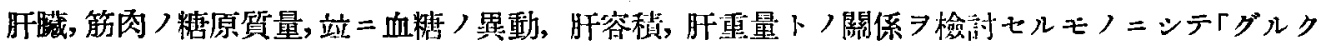

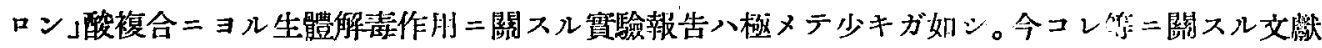

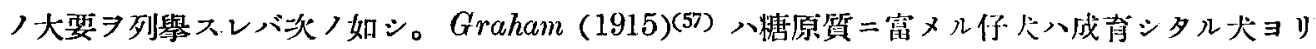

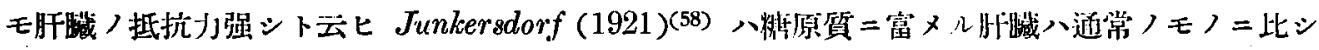

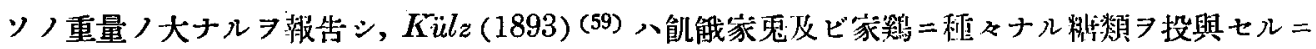

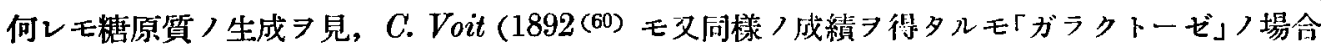

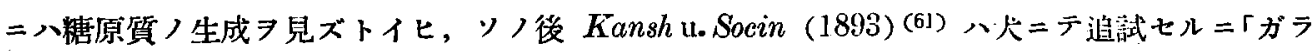

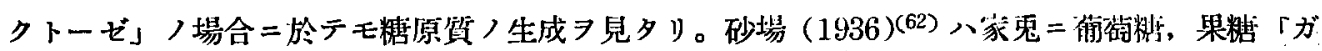

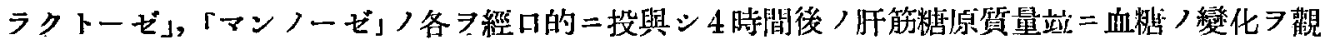

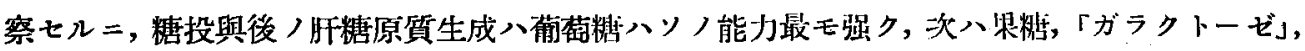

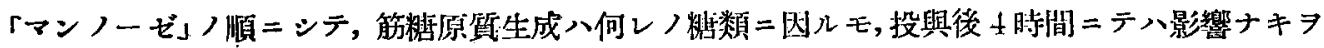

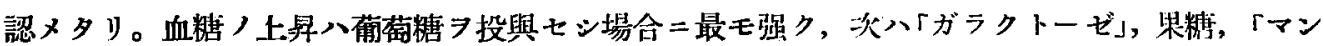

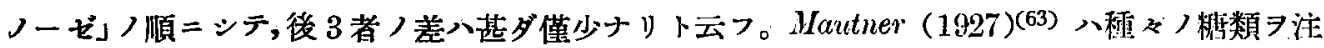

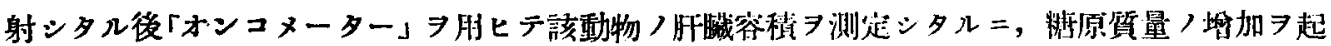


サシムル糖類注射ヨナシタル場合ノミ肝裁容揹ノ霄加ヨ認メ，然ラザル場合ニハ之ア認メズト 云へリ。

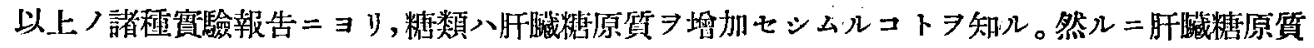
量ト肝臟機能ト八密接ナル關係ニアルコトハRoger $(1887)^{(64)}$ 以來多数研究者ニヨリ確認七ラレ タル處ナルョ以テ,生體ノ「グルクロン」酸複合ガモトシテ肝臟二於テ行ハルルモノトスレバ,糖

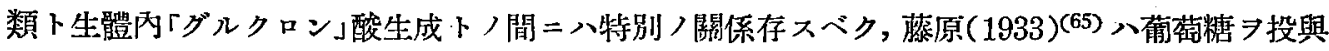
セバ之ヨ投與七ザル場合二比シ，明二複合「グルクロン」酸生成量つ增加セルタ認メタリト云フ。

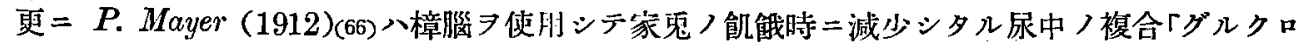

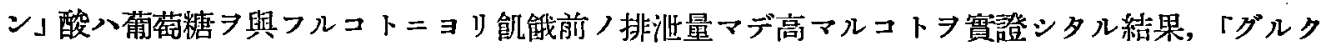
ロン」酸ノ根源入一部葡萢糖二起因スト諭ジタリ。

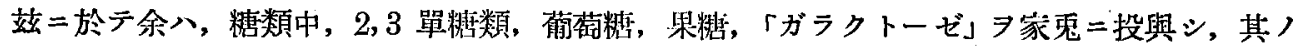
「グルクロン」酸生成 =及ボス影響习䫏察セル

余八余ノ現在ノ研究つ最終ノ目的タル葡葫糖「インュシリン」侍肘ノ生體內「グルクロン」酸 生成二及ス影響 メ，葡萄糖，果䌅，「ガラクトーゼ」ヨ飢能家鬼二投與シ，其ノ複合「グルクロン」酸生成ノ模樣 ア觀察シタリ。

\section{第 2 章 實驗材料及實驗方法}

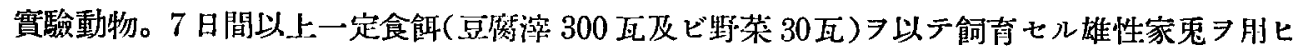
實驗開始卜同時二, 探尿裴置ア施七儿金屬製檻二容レ, 尿器ニハ少量ノトルオール」ヨ添加セリ。

食事。賽驗中八絕食トス。

探尿。賽驗開始時導尿 得タル尿二, 此ノ 24 時間內二尿器二溜リタル尿

體重。導尿直後二测定セり。

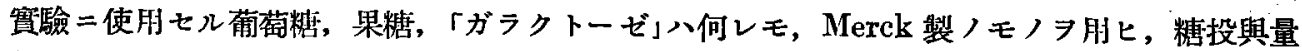

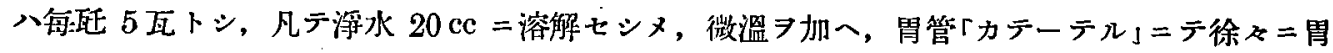
內二注入七リ。

「グルクロン」酸複合ノ椱合手トシテ八前賽驗同様局方「メントール」 2 瓦 75 竓ノ「オレンフ」 油二溶解セシメ, 微溫 $タ$ 加一家束, 背部皮下二注射七リ。

尿中ノケグルクロン」酸定量法八前編二於テ詳述七ル，A.J.Quick 法习䏚ヒタリ。何レモ各 1 日量ノ尿中ヨリ「グルクロン」酸ヨ定量セリ。

實驗〉順序：實驗開始當日ョリ動物フシテ絕食セシム。排尿後體重フ测定シハ「メントール」ヨ 注射ス。以後每日同時刻マデノ尿ニツキ「グルクロン」酸ヨ測定セリ。

絕食第 4 日同時刻=再ビ「メントール」ヨ注射シ，同時=水若クハ各種糖類溶液习投與シ，直 糖值ノ消長 $习$ 憸シ，注射後 3 日間ノ尿二就キ其ノ含倠「グルクロン」酸量 7 測定さリ。 


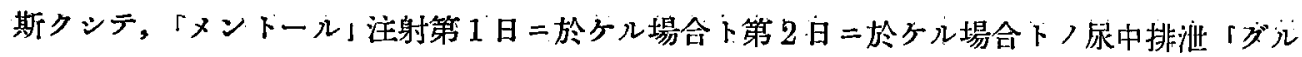
クロン」酸複合「メントール」量ヨ比较シ, 以テ糖類ガ複合「グルクロン」酸生成二及ボス影響ジ檢 シタリ。同時二血糖值 $゙$ 驗スルコトニョリ糖類ノ複合「グルクロン」酸生成二對スル影響卜血糖

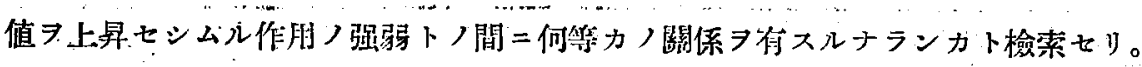

\section{第 3 章}

\section{第 1 節 飢餓時ニ於ケル「メントール、投與 I. II.トソ/排泄率（對照實驗）}

糖類投與ガ生體內「グルクロン」酸生成＝及ボス影響 つ意味 $=$ 於テ家鬼二飢解第 1 日ニ「メントール」ヨ投與シ，次デ飢解第 4 日二再ビ「メントール」

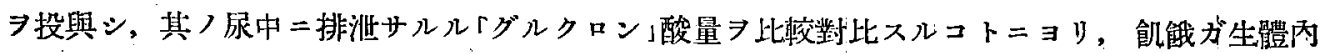
複合「グルクロン」酸生成二及ボス影響ヨ驗シタリ。

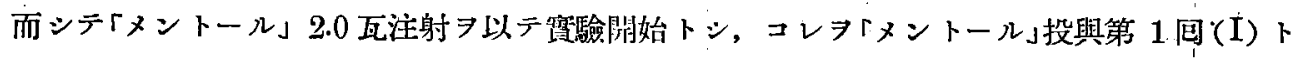
シ，實驗第 4 日再ビ「メントール」 2 瓦注射七ルモノタ「メントール」投與第 2 回(II) トナス。 カクシテ「メントール」投與 I. II. ノ各 3 日聞ノ尿中ノ「グルクロン」酸複合「メントール」量ノ大 小ヨ比较セリ。

「メントール」投與 IトIIトノ「メントール」排泄率ノ差八第 1 表二示スガ如シ。（第 1 表參照）

\begin{tabular}{|c|c|c|c|c|c|c|c|}
\hline & & & 第 & 1 & 表 & & . \\
\hline \multirow{2}{*}{$\begin{array}{l}\text { 家鬼 } \\
\text { 例數 }\end{array}$} & \multirow{2}{*}{ 實羷期閆 } & \multirow{2}{*}{$\begin{array}{c}\text { Tメントール」 } \\
\text { 投與特ノ家鬼 } \\
\text { 體重 } \\
\text { (毁) }\end{array}$} & \multicolumn{2}{|c|}{$\begin{array}{l}\text { 「メントール」 } \\
\text { 投舆 }\end{array}$} & \multirow{2}{*}{ 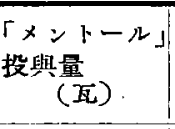 } & \multirow{2}{*}{$\begin{array}{l}\text { 「メントール」 } \\
\text { 排泄量，投與 } \\
\text { 量二對スル百 } \\
\text { 分比 }\end{array}$} & \multirow{2}{*}{$\stackrel{\text { 堆 }}{(+)}(\stackrel{\text { 減 }}{(-)}$} \\
\hline & & & 回數 & 期 日 & & & \\
\hline I & $\begin{array}{l}13 / \mathrm{XI} \\
19 / \mathrm{XI}\end{array}$ & $\begin{array}{l}2.270 \\
1.950\end{array}$ & II & $\begin{array}{l}13 / \mathbf{X I} \\
16 / \mathbf{X I}\end{array}$ & $\begin{array}{l}2.0 \\
2.0\end{array}$ & $\begin{array}{l}46.0 \\
26.0\end{array}$ & $(-) 20.0$ \\
\hline II & $\begin{array}{c}13 / \overline{X I} \\
1 \\
19 / \mathrm{XI}\end{array}$ & $\begin{array}{l}8.100 \\
1.800\end{array}$ & I & $\begin{array}{l}13 / \mathrm{XI} \\
16 / \mathrm{XI}\end{array}$ & $\begin{array}{l}2.0 \\
2.0\end{array}$ & $\begin{array}{l}72.0 \\
31.0\end{array}$ & $(-) 41.0$ \\
\hline III & $\begin{array}{c}0 / 1 \\
1 \\
15 \\
15 / 1\end{array}$ & $\begin{array}{l}1.950 \\
1.600\end{array}$ & I & $\begin{array}{r}9 / \mathbf{I} \\
12 / \mathbf{I}\end{array}$ & $\begin{array}{l}2.0 \\
2.0\end{array}$ & $\begin{array}{l}65.1 \\
20.6\end{array}$ & $(-) 44.5$ \\
\hline IV & $\begin{array}{c}13 / 1 \\
1 \\
19 / 1\end{array}$ & $\begin{array}{l}2.150 \\
1.890\end{array}$ & II & $\begin{array}{r}13 / \mathrm{I} \\
16 \mathrm{I}\end{array}$ & $\begin{array}{l}2.0 \\
2.0\end{array}$ & $\begin{array}{l}66.1 \\
39.1\end{array}$ & $(-) 27.0$ \\
\hline$V$ & $\begin{array}{c}1 / 1 \mathrm{I} \\
1 \\
2 / \mathrm{II}\end{array}$ & $\begin{array}{l}2.070 \\
1.700\end{array}$ & I & $\begin{array}{l}1 / I I \\
4 / I I\end{array}$ & $\begin{array}{l}2.0 \\
2.0\end{array}$ & $\begin{array}{l}43.2 \\
21.8\end{array}$ & $(-) 21.4$ \\
\hline 平 & 均 & & & & & & $(-) 30.8$ \\
\hline
\end{tabular}

第 2 節 飢餓 3 日後二淨水习投與セル場合ノ「メントール」

投與 I. II.トソ/排泄率ノ差站二血糖量ノ變化

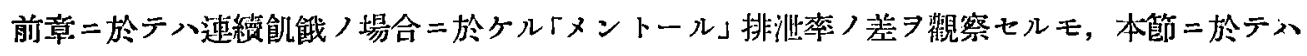

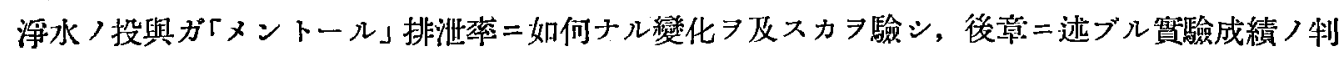
定ノ資トナセリ。郎チ「メントール」投與 I後 3 日ニシテ,「メントール」投與 II ト同時二淨水 20 䇅 
於ヶル血糖ノ異動 ヨモ覞察セリ。其ノ䁈驗成績八第 2 表(其ノ1)第 2 表(其ノ2 )二示スガ如シ。 第 2 表(其) 1 ，其 2 )寥䧂

$$
\text { 第 } 2 \text { 表 (其, } 1 \text { ) }
$$

\begin{tabular}{|c|c|c|c|c|c|c|c|c|c|}
\hline \multirow{2}{*}{$\begin{array}{l}\text { 家 } \\
\text { 鬼 } \\
\text { 例 } \\
\text { 數 }\end{array}$} & \multirow{2}{*}{ 苗酸期間 } & \multirow{2}{*}{ 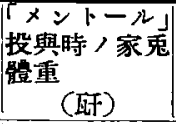 } & \multicolumn{2}{|c|}{$\begin{array}{l}\Gamma \times ン ト ー ル 」 \\
\text { 投與 }\end{array}$} & \multirow{2}{*}{$\mid \begin{array}{c}x=ト ー ル 」 \\
\text { 投與量 } \\
\text { (酉) }\end{array}$} & \multicolumn{2}{|c|}{ 淨水投與， } & \multirow{2}{*}{ 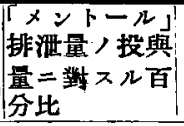 } & \multirow{2}{*}{$\stackrel{\text { 措 }}{(+)} \stackrel{\text { 娍 }}{(-)}$} \\
\hline & & & 回數 & 期 日 & & 期 日 & 量(靖) & & \\
\hline I & $\begin{array}{c}14 / \overline{X I I} \\
\downarrow \\
20 / \mathbf{X}^{2} \\
\end{array}$ & $\begin{array}{l}1.980 \\
1.770\end{array}$ & I & $\begin{array}{l}14 / \text { XII } \\
17 / \text { XII }\end{array}$ & $\begin{array}{l}2.0 \\
2.0\end{array}$ & $17 / \mathrm{XII}$ & 20.0 & $\begin{array}{l}66.0 \\
40.0\end{array}$ & $(-) 26.0$ \\
\hline II & $\begin{array}{c}21 / X I I \\
\downarrow \\
2 \pi / X I I ~\end{array}$ & $\begin{array}{l}2.210 \\
1.980\end{array}$ & I & $\begin{array}{l}21 / \text { XII } \\
24 / \text { XII }\end{array}$ & $\begin{array}{l}2.0 \\
2.0\end{array}$ & 24/XII & 20.0 & $\begin{array}{l}39.0 \\
25.0\end{array}$ & $(-) 14.0$ \\
\hline III & $\begin{array}{c}24 / \mathrm{XII} \\
\downarrow \\
30 / \mathrm{XII}\end{array}$ & $\begin{array}{l}1.780 \\
1.520\end{array}$ & II & $\begin{array}{l}24 / X I I \\
27 / X I I\end{array}$ & $\begin{array}{l}2.0 \\
2.0\end{array}$ & $27 / \mathrm{XII}$ & 20.0 & $\begin{array}{l}47.5 \\
35.3\end{array}$ & $(-) 12.2$ \\
\hline IV & $\begin{array}{c}7 / 1 \\
13 / I \\
\end{array}$ & $\begin{array}{l}2.300 \\
2.000\end{array}$ & II & $\begin{array}{c}7 / \mathbf{I} \\
10 / \mathbf{I}\end{array}$ & $\begin{array}{l}2.0 \\
2.0\end{array}$ & $10 / I$ & 20.0 & $\begin{array}{l}67.7 \\
42.0\end{array}$ & $(-) 25.7$ \\
\hline$\nabla$ & $\begin{array}{c}7 / I \\
13 / I\end{array}$ & $\begin{array}{l}1.970 \\
1.670\end{array}$ & II & $\begin{array}{r}\pi / \mathrm{I} \\
10 / \mathrm{I}\end{array}$ & $\begin{array}{l}2.0 \\
2.0\end{array}$ & $10 / I$ & 20.0 & $\begin{array}{l}66.2 \\
42.0\end{array}$ & $(-) 24.2$ \\
\hline 平 & 均 & & & & & & & & $(-) 20.4$ \\
\hline
\end{tabular}

第 2 表 (其, 2)

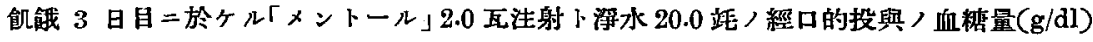

\begin{tabular}{|c|c|c|c|c|c|c|c|c|c|}
\hline 䔬驗 & $\begin{array}{c}\text { 投 舆 } \\
\text { 期 }\end{array}$ & 投與前 & $\begin{array}{l}\text { 水/投 } \\
\text { 與量 } \\
\text { (圫) }\end{array}$ & $\begin{array}{l}\text { 投 興唛 } \\
1 / 2 \text { (時) }\end{array}$ & $\begin{array}{l}\text { 投與唛 } \\
1.0 \text { (時) }\end{array}$ & $\begin{array}{l}\text { 投與後 } \\
11 / 2 \text { (時) }\end{array}$ & $\begin{array}{l}\text { 投與後 } \\
2.0 \text { (時) }\end{array}$ & $\begin{array}{l}\text { 投與後 } \\
3.0 \text { (時) }\end{array}$ & 4.0 (時) \\
\hline$\underset{\text { IV }}{\stackrel{I}{I I}}$ & $\begin{array}{l}17 / \text { XII } \\
24 / \text { XII } \\
27 / \text { XII } \\
29 / \text { XII } \\
10 / \text { I } \\
\text { 平均 }\end{array}$ & $\begin{array}{l}0.092 \\
0.099 \\
0.117 \\
0.124 \\
0.124 \\
0.111\end{array}$ & $\begin{array}{c}20.0 \\
11 \\
11 \\
11 \\
11\end{array}$ & $\begin{array}{l}0.106 \\
0.117 \\
0.122 \\
0.184 \\
0.145 \\
0.134\end{array}$ & $\begin{array}{l}0.111 \\
0.122 \\
0.124 \\
0.188 \\
0.145 \\
0.138\end{array}$ & $\begin{array}{l}0.111 \\
0.130 \\
0.120 \\
0.191 \\
0.148 \\
0.140\end{array}$ & $\begin{array}{l}0.096 \\
0.132 \\
0.117 \\
0.175 \\
0.132 \\
0.130\end{array}$ & $\begin{array}{l}0.095 \\
0.117 \\
0.115 \\
0.166 \\
0.130 \\
0.124\end{array}$ & $\begin{array}{l}0.092 \\
0.095 \\
0.115 \\
0.144 \\
0.126 \\
0.114\end{array}$ \\
\hline & & & 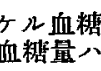 & 8 & & & & & \\
\hline
\end{tabular}

\section{第 3 節 飢餓 3 日後二葡萄糖习投與セル場合ノ「メントール」}

\section{投與 I. II. トソノ排泄率ノ差, 立二血糖ノ變化}

糖類投與ノ生體內「グルクロン」酸生成ニ及ボス影響ヨ筧ハントシ，飢能第 1 日ニ「メントー

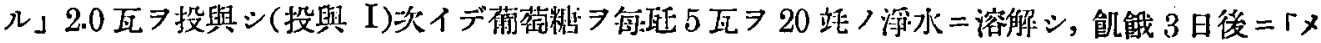
ントール」 2 瓦注射(投與 II) ト同時二經口的二投與セリ。ソノ場合ノ「メントール」投與 Iト「メ ントール」投與 IIトノ「メントール」排泄率ノ塯減八第 3 表(其ノ1) =示スガ如シ。第 3 表（其 > 1) 參照

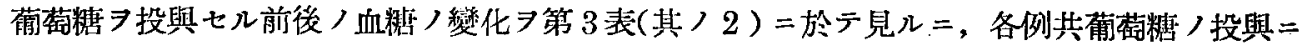

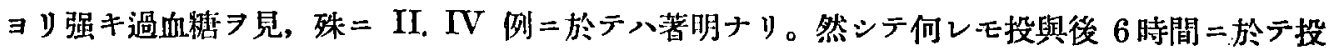

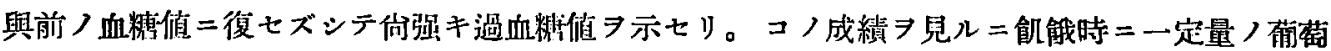


第 3. 表 (其, 1 )

\begin{tabular}{|c|c|c|c|c|c|c|c|c|c|}
\hline \multirow{2}{*}{$\begin{array}{l}\text { 家鬼 } \\
\text { 例數 }\end{array}$} & \multirow{2}{*}{ 惯哈期間 } & \multirow{2}{*}{ 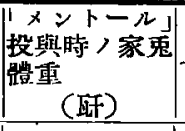 } & \multicolumn{2}{|c|}{ 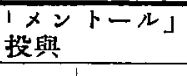 } & \multirow{2}{*}{ 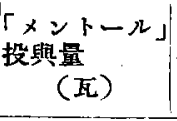 } & \multicolumn{2}{|c|}{ 菊萄糖投與 } & \multirow{2}{*}{$\mid \begin{array}{l}x \text { メーール } \\
\text { 排泄量／投與 } \\
\text { 量二對 スル百 } \\
\text { 分比 }\end{array}$} & \multirow{2}{*}{$\stackrel{\text { 堵 }}{(+)}(\stackrel{\text { 娍 }}{(-)}$} \\
\hline & & & 回數 & 期 日 & & 期 日 & 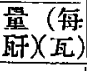 & & \\
\hline I & $\begin{array}{c}5 / \mathrm{XII} \\
\downarrow \\
11 / \mathrm{XII}\end{array}$ & $\begin{array}{l}2.150 \\
1.880\end{array}$ & I & $\begin{array}{l}5 / X I I \\
8 / X I I\end{array}$ & $\begin{array}{l}2.0 \\
2.0\end{array}$ & 8/XII & 5.0 & $\begin{array}{l}30.0 \\
31.4\end{array}$ & $(+) 1.4$ \\
\hline II & $\begin{array}{c}7 \mathrm{XII} \\
1 \\
13 / \mathbf{X} I I\end{array}$ & $\begin{array}{l}2.450 \\
2.110\end{array}$ & I & $\begin{array}{r}7 / \text { XII } \\
10 / \text { XII }\end{array}$ & $\begin{array}{l}2.0 \\
2.0\end{array}$ & 10/XII & 5.0 & $\begin{array}{l}47.0 \\
44.4\end{array}$ & $(-) 2.6$ \\
\hline III & $\begin{array}{r}18 / 1 \\
\vdots \\
24 / 1\end{array}$ & $\begin{array}{l}2.100 \\
1.750\end{array}$ & I & $\begin{array}{l}18 / I \\
24 / I\end{array}$ & $\begin{array}{l}2.0 \\
2.0\end{array}$ & $21 / I$ & 5.0 & $\begin{array}{l}64.1 \\
63.9\end{array}$ & $(-) 0.2$ \\
\hline IV & $\begin{array}{c}30 / \mathrm{I} \\
\downarrow \\
5 / \mathrm{II}\end{array}$ & $\begin{array}{l}2.100 \\
1.750\end{array}$ & I & $\begin{array}{l}30 / \mathbf{I} \\
2 / \mathbf{I I}\end{array}$ & $\begin{array}{l}2.0 \\
2.0\end{array}$ & $2 / I I$ & 5.0 & $\begin{array}{l}33.2 \\
45.2\end{array}$ & $(+) 12.0$ \\
\hline$\Gamma$ & $\begin{array}{c}6 / 1 \mathrm{I} \\
\vdots \\
12 / \mathrm{II} \\
\end{array}$ & $\begin{array}{l}1.920 \\
1.720\end{array}$ & II & $\begin{array}{l}6 / \mathbf{I I} \\
9 / \mathbf{I I}\end{array}$ & $\begin{array}{l}2.0 \\
2.0\end{array}$ & $9 / \mathbf{I I}$ & 5.0 & $\begin{array}{l}54.2 \\
59.8\end{array}$ & $(+) 5.6$ \\
\hline II & $\begin{array}{c}8 / \overline{I I} \\
\downarrow \\
14 / \mathrm{II}\end{array}$ & $\begin{array}{l}2.100 \\
1.800\end{array}$ & I & $\begin{array}{r}8 / \mathbf{I I} \\
11 / I I\end{array}$ & $\begin{array}{l}2.0 \\
2.0\end{array}$ & $11 / \mathrm{II}$ & 5.0 & $\begin{array}{l}52.6 \\
59.7\end{array}$ & $(+) 7.1$ \\
\hline 平 & 均 & & & & & & & & $(+) 3.7$ \\
\hline
\end{tabular}

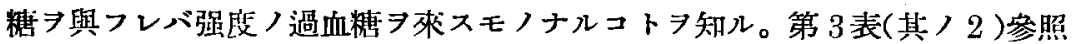

$$
\text { 第 } 3 \text { 表 (其, } 2 \text { ) }
$$

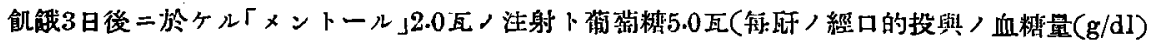

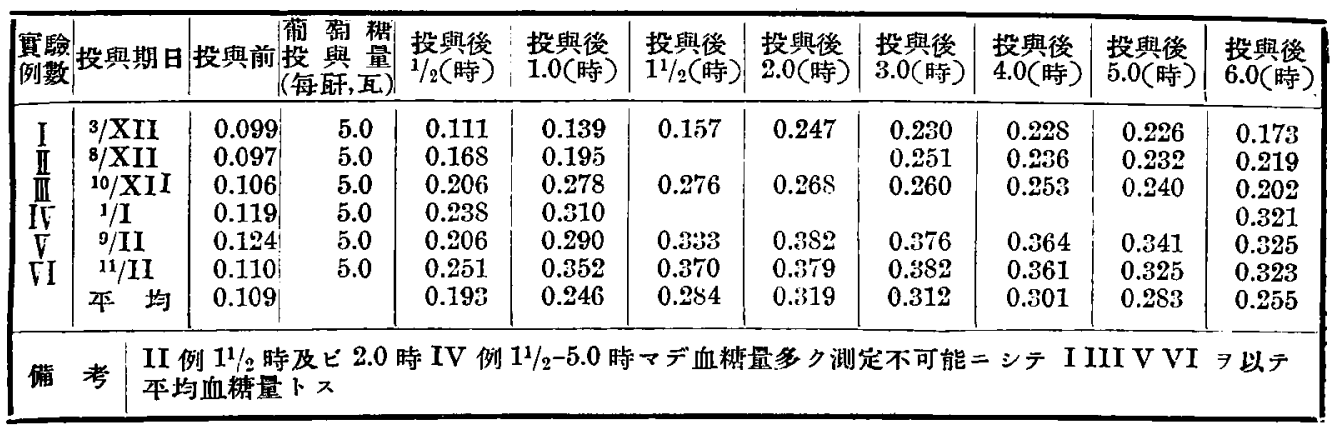

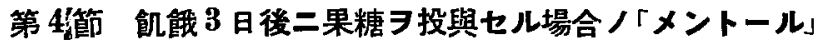

\section{. 投與 I. II. トソノ排泄率ノ差竝ニ血糖值ノ異動}

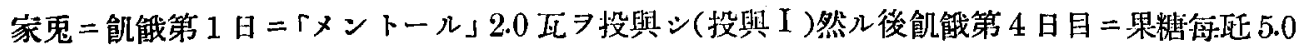
瓦 720 圫/淨水二溶解セシメ,「メントール」ノ注射卜同時=經口的二投與(投與 II )セリ。ソ ノ成績八第 4 表(其ノ 1 ) $=$ 示スガ如シ。第 4 表(其ノ 1 )寥照

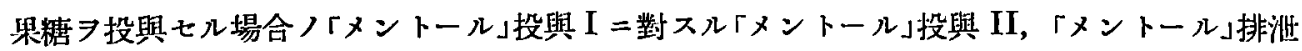

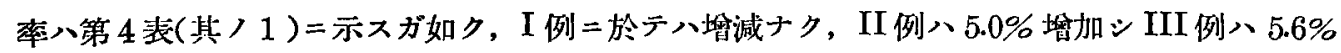
減少シ, IV 例二於テハ $2.0 \%, \mathrm{~V}$ 例八 $7.4 \%, \mathrm{VI}$ 例入 $6.3 \%$ /何レモ減少セリ。コノ条例ノ 增減率 7 平均スレバ $2.8 \%$ 減少 
第 4 表 .(㙋, 1 )

\begin{tabular}{|c|c|c|c|c|c|c|c|c|c|}
\hline \multirow{2}{*}{$\begin{array}{l}\text { 家串 } \\
\text { 例數 }\end{array}$} & \multirow{2}{*}{ 筫匳期聞 } & \multirow{2}{*}{ 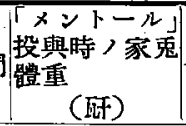 } & \multicolumn{2}{|c|}{$\begin{array}{l}\text { 投ントール」 } \\
\text { 捡 }\end{array}$} & \multirow{2}{*}{ 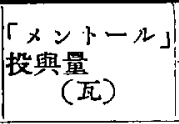 } & \multicolumn{2}{|c|}{ 果糖投與 } & \multirow{2}{*}{ 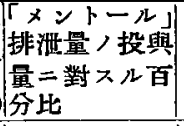 } & \multirow{2}{*}{$(+)(-)$} \\
\hline & & & 回數 & 虭 日 & & 期 日 & 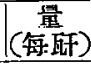 & & \\
\hline I & $\begin{array}{c}10 / \mathrm{XII} \\
\downarrow \\
16 / \stackrel{\text { XII }}{ }\end{array}$ & $\begin{array}{l}2.160 \\
1.870\end{array}$ & I & $\begin{array}{l}\text { 10/XII } \\
13 / \text { XII }\end{array}$ & $\begin{array}{l}2.0 \\
2.0\end{array}$ & 13/XII & 5.0 & $\begin{array}{l}62.0 \\
62.0\end{array}$ & 0 \\
\hline II & $\begin{array}{r}16 / I \\
\downarrow \\
22 / I \\
\end{array}$ & $\begin{array}{l}2.240 \\
2.000\end{array}$ & I & $\begin{array}{l}\text { 12/XII } \\
15 / \mathrm{XII}\end{array}$ & $\begin{array}{l}2.0 \\
2.0\end{array}$ & 15/XII & 5.0 & $\begin{array}{l}49.0 \\
54.0\end{array}$ & $(+) 5.0$ \\
\hline III & $\begin{array}{c}30 / I \\
\downarrow \\
5 / I\end{array}$ & $\begin{array}{l}2.300 \\
2.070\end{array}$ & $\stackrel{\text { I }}{\text { II }}$ & $\begin{array}{l}16 / I \\
19 / I\end{array}$ & $\begin{array}{l}2.0 \\
2.0\end{array}$ & 19/XII & 5.0 & $\begin{array}{l}44.8 \\
39.2\end{array}$ & $(-) 5.6$ \\
\hline IV & $\begin{array}{r}6 / 11 \\
\downarrow \\
12 / 11\end{array}$ & $\begin{array}{l}2.050 \\
1.750\end{array}$ & II & $\begin{array}{l}30 / I \\
2 / I I\end{array}$ & $\begin{array}{l}2.0 \\
2.0\end{array}$ & $2 / I I$ & 5.0 & $\begin{array}{l}48.7 \\
46.7\end{array}$ & $(-) 2.0$ \\
\hline V & $\begin{array}{c}15 / I I \\
\vdots \\
21 / \text { II }\end{array}$ & $\begin{array}{l}2.100 \\
1.810\end{array}$ & I & $\begin{array}{l}6 / I I \\
9 / I I\end{array}$ & $\begin{array}{l}2.0 \\
2.0\end{array}$ & $9 / \mathrm{II}$ & 5.0 & $\begin{array}{l}47.5 \\
40.1\end{array}$ & $(-) 7.4$ \\
\hline$\nabla J$ & $\begin{array}{c}15 / I I \\
\downarrow \\
21 / I I\end{array}$ & $\begin{array}{l}2.300 \\
2.050\end{array}$ & I & $\begin{array}{l}15 / \mathrm{II} \\
18 / 1 \mathrm{I}\end{array}$ & $\begin{array}{l}2.0 \\
2.0\end{array}$ & $18 / I I$ & 5.0 & $\begin{array}{l}57.5 \\
51.2\end{array}$ & $(-) 6.3$ \\
\hline 平 & 均 & & & & & & & & $(-) 2.8$ \\
\hline
\end{tabular}

ル」排泄率入減少セルラ認メタリ。第 4 表(其ノ 1 )參照

果糖 $习$ 投與七ル場合〉血糖量〉異動ハ第 4 表(其ノ 2 )二示ス如シ。

$$
\text { 第 } 4 \text { 表 (其, } 2 \text { ) }
$$

彾能3日後二於ヶル「メントール」2.0瓦ノ注射ト果糖 5.0 瓦

(每刵)，䋔口的投與，血糖量 (g/dl)

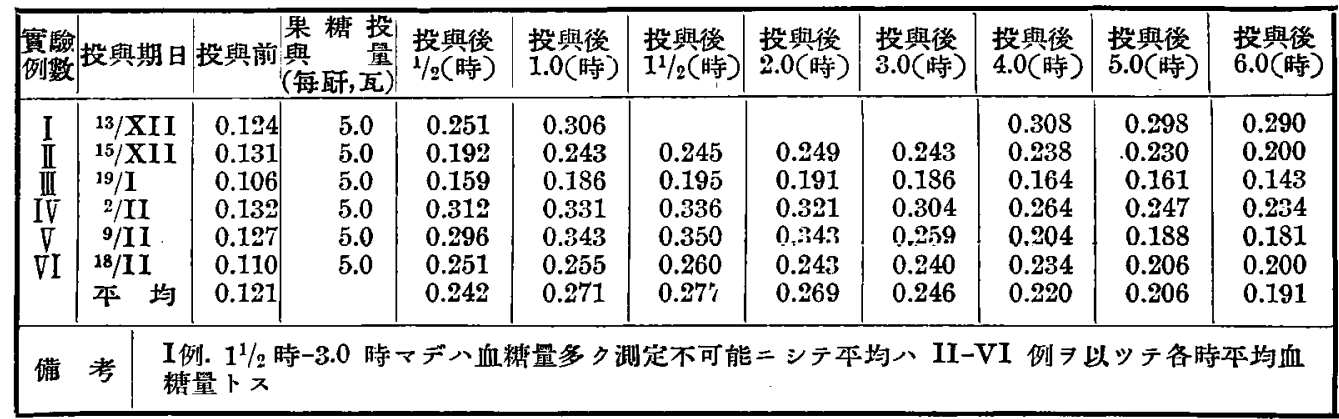

果糖投與ノ場合ノ血糖值つ變動ラ゙第 4 表(其ノ 2 ) =就テ見ル =果䌅投與前=比シ投與後八過 血糖 示シ殊 $=$ II 例=於テハ最モ强キ過血糖ヨ示シ，投與後 6 時間二於テ見ルモ投與前 $/$ 血

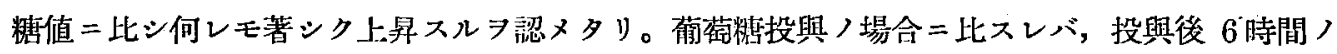
平均血糖值八低ク稍投與前ノ血粘值二復スル傾向ノ强キヨ認ムルモノナリ。第 4 表(其ノ2)

第 5 節 飢餓 3 日媵ニ「ガラタトーゼ」ヨ投與セル場合ノ「メントール」

\section{投與 I. II. トソノ排泄率ノ差竝ニ血糖ノ異動}

最後ニ「ガラクトーゼ」投與）場合二於ケル「メントール」投與 I ト「メントール」投與 II (间 
時ニ「ガラクトーゼ」ヨ投與)トノ「メントール」ノ排泄率ノ增減す觀察セリ。

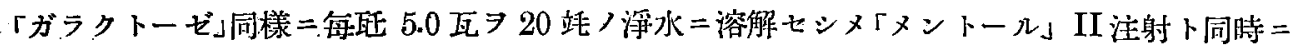
經口的ニ投與セリ。ソノ賽驗成䋶八第 5 表(其) 1 ) ノ如シ。

第 5 表 (其, 1 )

\begin{tabular}{|c|c|c|c|c|c|c|c|c|c|}
\hline 家鬼， & 崖麐期 & $\mid \begin{array}{l}\text { 「メントール」 } \\
\text { 投與特ノ家鬼 }\end{array}$ & $\begin{array}{l}5 \times 2 \\
\text { 投與 }\end{array}$ & 一トル」 & 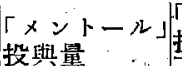 & $\begin{array}{l}\Gamma \boldsymbol{L}^{\circ} \ni \\
\text { 投斯 }\end{array}$ & クトーゼ」 & 排沚量，投與 & 管 減 \\
\hline 例數 & 15 ind & (歼) & 回数 & 期 日 & (瓦) & 期日 & 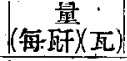 & $\mid \begin{array}{l}\text { 量二数スル百 } \\
\text { 比 }\end{array}$ & $(+)(-)$ \\
\hline I & $\begin{array}{r}25 / 1 \\
\downarrow \\
31 / 1 \\
\end{array}$ & $\begin{array}{l}2.200 \\
1.830\end{array}$ & I & $\begin{array}{l}25 / I \\
28 / I\end{array}$ & $\begin{array}{l}2.0 \\
2.0\end{array}$ & $28 / I$ & 5.0 & $\begin{array}{l}60.0 \\
48.5\end{array}$ & $(-) 11.5$ \\
\hline II & $\begin{array}{c}28 / \mathrm{I} \\
\downarrow \\
3 / \mathrm{II}\end{array}$ & $\begin{array}{l}2.310 \\
2.100\end{array}$ & $:$ II & $\begin{array}{l}28 / I \\
31 / I\end{array}$ & $\begin{array}{l}2.0 \\
2.0\end{array}$ & $31 / I$ & 5.0 & $\begin{array}{l}62.7 \\
48.8\end{array}$ & $(-) 13.9$ \\
\hline III & $\begin{array}{c}31 / 1 \\
t \\
6 / I I \\
\end{array}$ & $\begin{array}{l}2.100 \\
1.980\end{array}$ & I & $\begin{array}{l}31 / \mathbf{I} \\
3 / \mathbf{I} I\end{array}$ & $\begin{array}{l}2.0 \\
2.0\end{array}$ & $3 / \mathrm{II}$ & 5.0 & $\begin{array}{l}64.6 \\
50.8\end{array}$ & $(-) 13.8$ \\
\hline IV & $\begin{array}{c}12 / \mathbf{L I} \\
\vdots \\
\mathbf{2 0} / \mathbf{I I}\end{array}$ & $\begin{array}{l}2.140 \\
1.880\end{array}$ & II & $\begin{array}{l}14 / I I \\
17 / I I\end{array}$ & $\begin{array}{l}2.0 \\
2.0\end{array}$ & $17 / \mathrm{II}$ & 5.0 & $\begin{array}{l}46.3 \\
42.2\end{array}$ & $\left(\frac{\sqrt{2}}{-}\right) 4.1$ \\
\hline V & $\begin{array}{c}1+/ I I \\
\vdots \\
20 / I I \\
\end{array}$ & $\begin{array}{l}2.050 \\
1.820\end{array}$ & $\frac{\mathrm{I}}{\text { II }}$ & $\begin{array}{l}11 / \mathrm{II} \\
17 / \mathrm{II}\end{array}$ & $\begin{array}{l}2.0 \\
2.0\end{array}$ & $17 / I I$ & 5.0 & $\begin{array}{l}38.3 \\
28.0\end{array}$ & $(-) 10.3$ \\
\hline VI & $\begin{array}{c}21 / \mathbf{I I} \\
\downarrow \\
27 / \mathbf{I I} \\
\end{array}$ & $\begin{array}{l}1.900 \\
1.660\end{array}$ & I & $\begin{array}{l}21 / \text { II } \\
24 / I I\end{array}$ & $\begin{array}{l}2.0 \\
2.0\end{array}$ & 14/II & 5.0 & $\begin{array}{l}28.0 \\
51.2\end{array}$ & $(-) 9.7$ \\
\hline 平 & 均 & & & & & & & & $(-) 10.6$ \\
\hline
\end{tabular}

以上各例ノ「メントール」投與 Iト「メントール」投與 II トノ「メントール」排泄率ノ堌隇 見 $=$, I 例 $11.5 \%$, II 例 $13.9 \%$, III 例 $13.8 \%$, IV 例 $4.1 \%, \mathrm{~V}$ 例 $1.03 \%$, VI 例 $9.7 \%$, 何レモ減少ヨ示シ,增加ヨ示七ルモ/ 1 例モ認メズ,ソ/本均減少率八 $10.6 \%$ ナ。コ/減少 率 7 前 2 者葡萄, 粝果糖ノ場合二比スレバ,ソノ差著シク，果糖ノ次位ニアルモノト思惟七ラル。

「ガラクトーゼ」投與〉場合ノ血糖ノ異動八第5表(其ノ2)二示スガ如シ。[第 5 表(其ノ2)參照]

$$
\text { 第 } 5 \text { 表 (其, } 2 \text { ) }
$$

欱解 3 日後ニ於ケル「メントール」2.0 瓦 ノ注射ト「ガラクトーゼ」

50 瓦(每刵) , 縚口的投與, 血裙量 $(\mathrm{g} / \mathrm{dl})$

\begin{tabular}{|c|c|c|c|c|c|c|c|c|c|c|c|}
\hline $\begin{array}{l}\text { 實驗 } \\
\text { 例数 }\end{array}$ & 役與 & 投與前 & 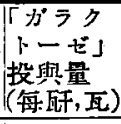 & $\begin{array}{l}\text { 投與後 } \\
1 / 2 \text { (時) }\end{array}$ & $\begin{array}{l}\text { 投與後 } \\
1.0 \text { (時) }\end{array}$ & $\begin{array}{l}\text { 投與後 } \\
1^{1 / 2} \text { (時) }\end{array}$ & $\begin{array}{l}\text { 投與後 } \\
2.0 \text { (時) }\end{array}$ & $\begin{array}{l}\text { 投與後 } \\
3.0 \text { (時) }\end{array}$ & $\begin{array}{l}\text { 投與後 } \\
4.0 \text { (時) }\end{array}$ & $\begin{array}{l}\text { 投與後 } \\
5.0 \text { (時) }\end{array}$ & $\begin{array}{l}\text { 投與後 } \\
6.0 \text { (時) }\end{array}$ \\
\hline & $28 / I$ & 0.136 & 5.0 & 0.208 & 0.228 & 0.232 & 0.245 & 0.236 & 0.232 & 0.204 & 0.171 \\
\hline & $31 / \bar{I}$ & 0.125 & 5.0 & 0.184 & 0.236 & 0.247 & 0.262 & 0.259 & 0.230 & 0.200 & 0.166 \\
\hline & $3 / \mathbf{I I}$ & 0.124 & 5.0 & 0.168 & 0.204 & 0.208 & 0.219 & 0.266 & 0.241 & 0.217 & 0.209 \\
\hline IV & $17 / \mathrm{II}$ & 0.088 & 5.0 & 0.127 & 0.181 & 0.193 & 0.217 & 0.245 & 0.232 & 0.200 & 0.172 \\
\hline 1 & $24 / \mathrm{II}$ & 0.131 & 5.0 & 0.195 & 0.255 & 0.270 & 0.294 & 0.314 & 0.321 & 0.286 & 0.226 \\
\hline 7 & $17 /$ III & 0.106 & 5.0 & & 0.211 & 0.219 & 0.228 & 0.217 & 0.209 & 0.202 & 0.193 \\
\hline & 平均 & 0.135 & & 0.172 & 0.219 & 0.224 & 0.244 & 0.256 & 0.244 & 0.218 & 0.188 \\
\hline
\end{tabular}

第 4 章 總括及ビ考察

1）第 1 章第 1 節 $コ$ リ第 5 節 $=$ 至ル實驗成績 7 總合シテ表示スル 第 6 表(其) 1 ) ノ如シ， 
節チ飢餓時「メントール」ヨ投塡シタル場合其ノ「グルクロン」酸二複合サレテ尿中二排泄サルル 「メントール」量/投與「メントール」量二對スル百分比八淨水「ガラクトーゼ」, 果䌅, 葡萄糖,

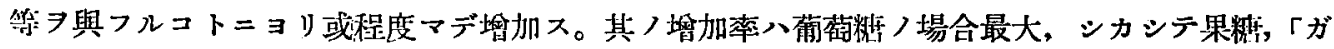
ラクトーゼ」ノ順二之二次ギ淨水/場合八其傯加率最小ナリ。[第 6 表(其ノ 1 )参炤]

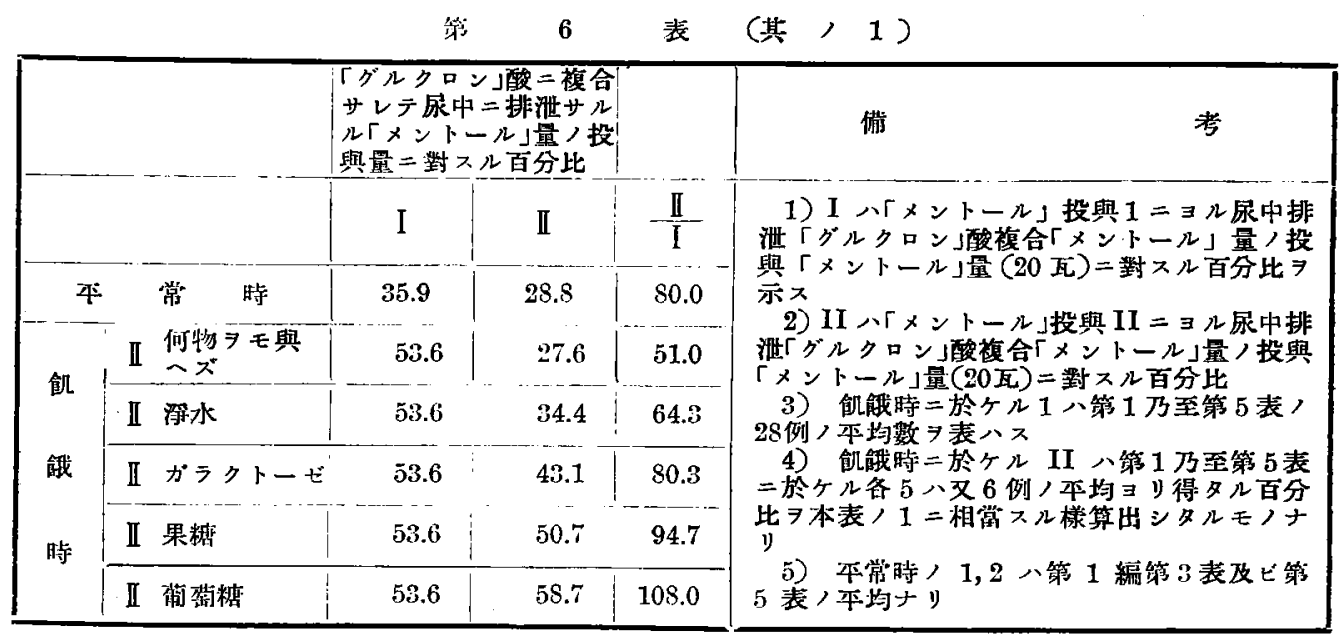

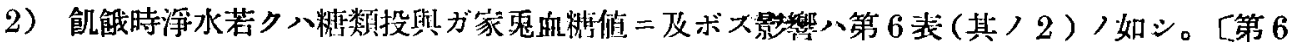
表(其, 2 )參照]

第 6 表 (其, 2 )

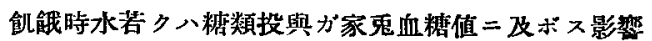

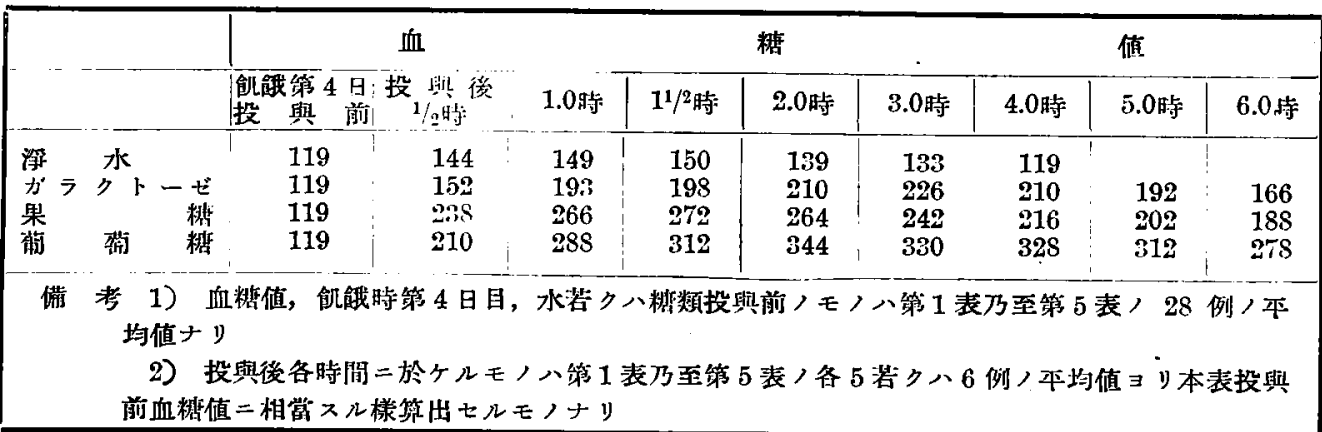

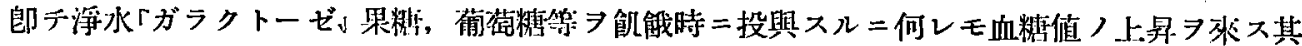
ノ上昇度八葡萄糖最モ大ニシテ果糖「ガラクトーゼ」淨水ノ顺ニとレニ次グ。

3）䌅類ニシテ其ノ血糖俻上:䒜度大ナルモノホド尿中二排沘サルル「グルクロン」酸複合「メ ントール」量ノ增加率ヨシテ大ナラシム。 


\section{第 3 編 生體內「メントールグルクロン」酸生成ノ葡萄䌅}

\section{「インシユリン」噺用ニヨル影響ニ就テ}

目次

第 1 章 緒 諭

第 2 章 筫驗方法

第 3 音 實驗成繥

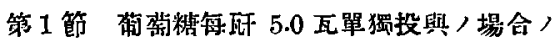

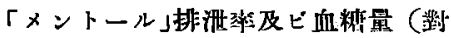
照窟驗)

第 2 節 菊菊糖每瓦 5.0 瓦「インシュリン」何: 瓦 0.5 單位用入場合,「メントー ル」排泄秦及ビ血檄量

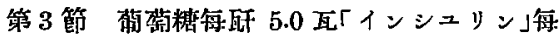
皌 1.0 單位借用合，「メントー ル」排渔率及ビ血精量。

第 4 節 葡葡糖每刵 5.0 瓦「インシュリン」每
狂 2.0 單位俾甲/場合「「メントー

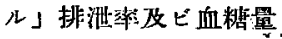

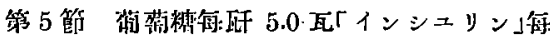
研 4.0 單位伤雨/場合,「メントー ル」排㴤涂及ビ血糖量

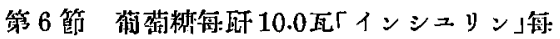

一既 1.0 單位伤用ノ場合ノ「メントー

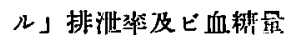

第 7 節 葡萌粕每刵 10.0 瓦「インシュリン」每 瓦 4.0 單位併用/場合「「ントー ル」排汫旁及ビ血糖量

第 4 音 總括及ビ考察 主要文器

\section{第 1 章 緒言}

余八本論文, 第 2 編二於テ糖類(葡萄糖, 果糖, 「ガラクトーゼ」)投與)生體內「グルクロン」

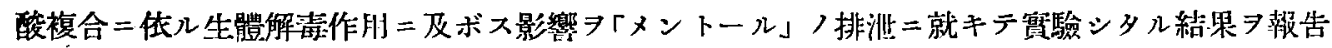
七り。

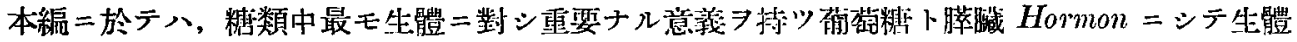

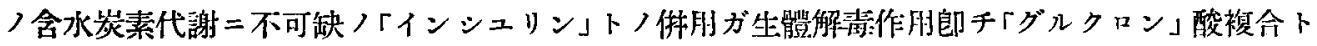
ソノ排泄二及ボス影響二就テ䫏察七ル所ヨ述ベントス。

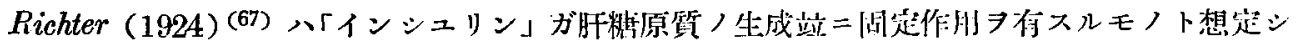

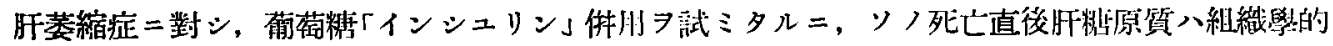

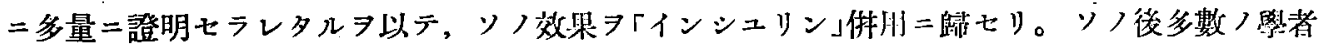

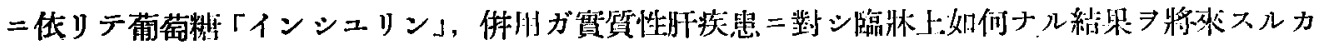

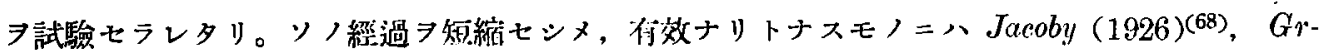
unenberg $(1926)^{(69)}$, Rosenberg (1926) (70), Hersky (1926)(71), Eppidger (1926) (72), Klein

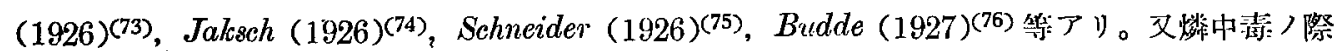

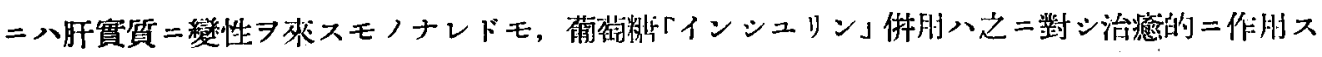

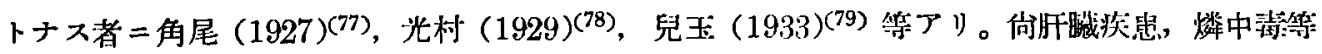

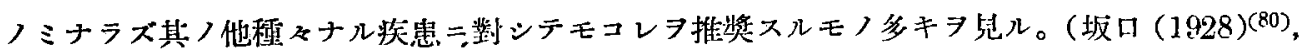
大里 $(1933)^{(81)}$, 金子 $(1934)^{(82)\left(\frac{45}{\sigma^{5}}\right) 。}$

然レドモ本邦二於テヘ山川 $(1934)^{(83)}$ 及ビソノ阴下八肝桨患二對スル葡萄糖「インシュリン」 


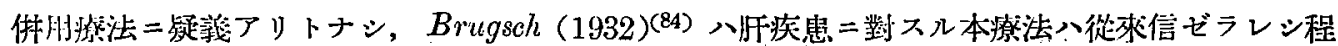

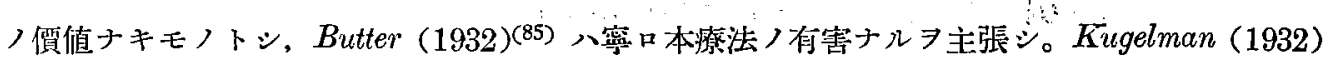

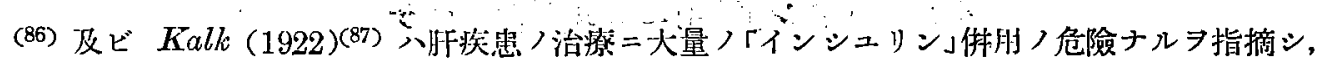

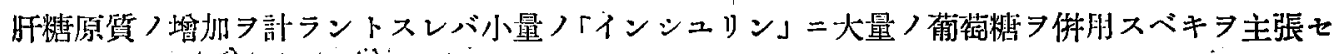

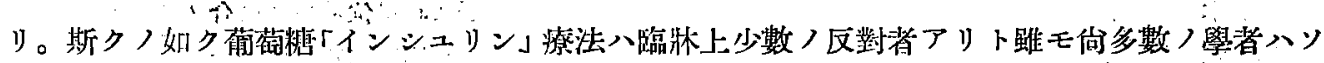

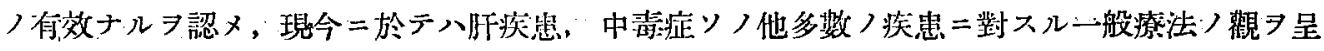

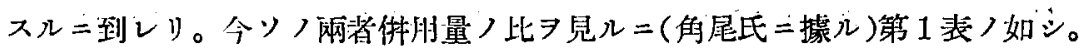

第 1 表

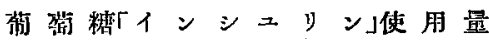

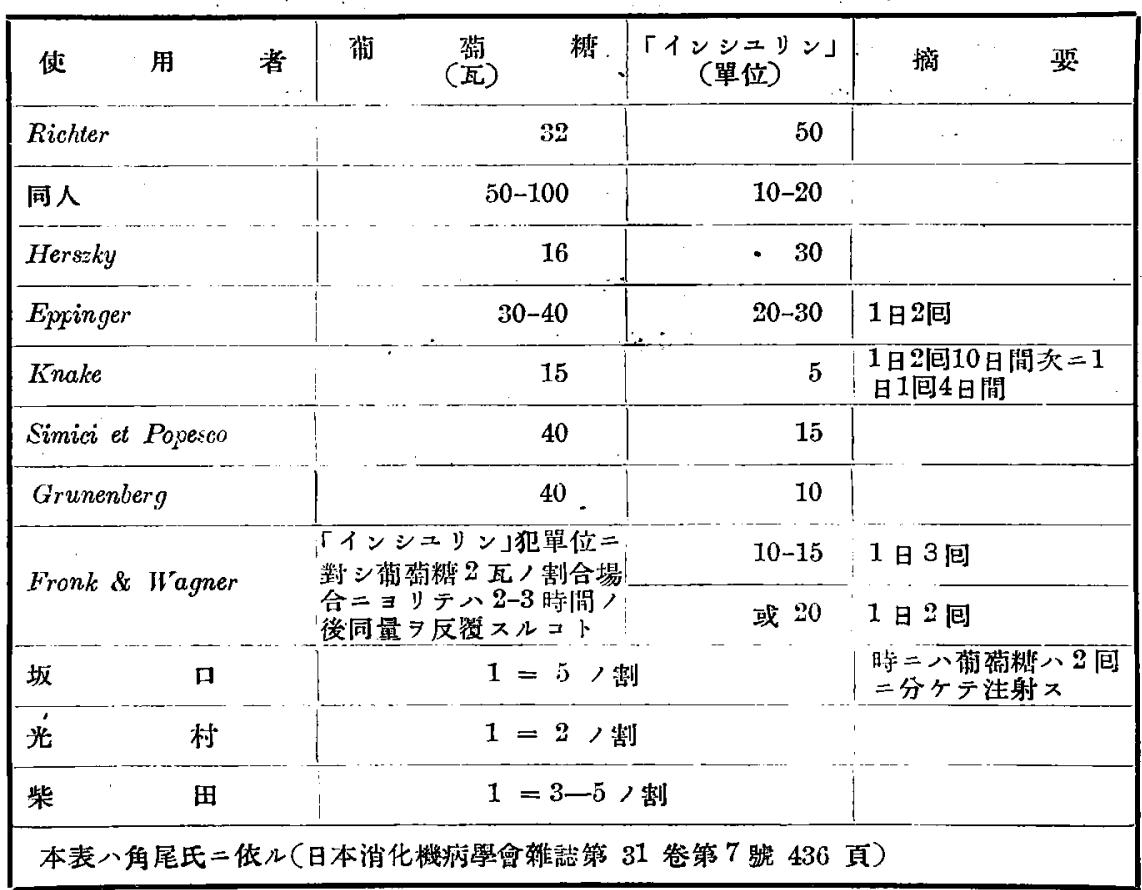

以上八本療法つ臨牀報告ノ大要ナレドモ，本問題=關シ實驗的ニソノ利害ヨ檢討追試セれ者

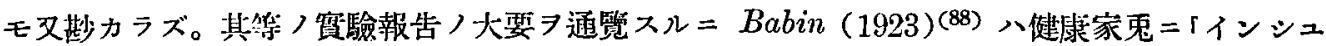
リン」(0.02 或八0.007瓦)ヨ注射シ肝糖原質ノ減少

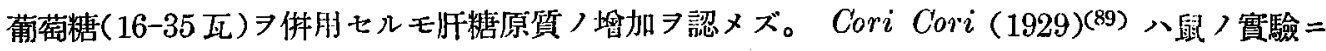
於テ每時間體重 100 瓦二對シ葡萄糖(20\%溶液) 0.4 瓦习注入七ル

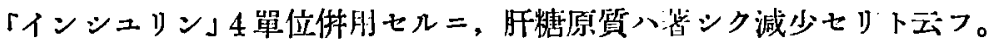

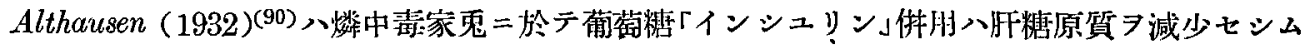
ルモノトナシ, Bode \& Neuwirth $(1933)^{(91)}$ 八正常犬二於テ糖投與二際シ大量ノ「インシュリ ン」ヨ件州スレバ, 肝糖原質ハ減少スル 


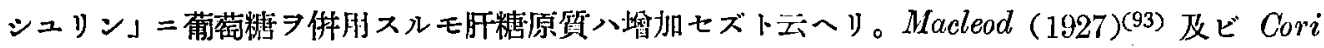

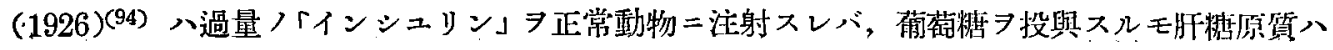
增加セズシテ, 却ツテ減少スルコトアリトナシ，Cori 八少量ノ「インシュリン」ト葡䓒糖ト 件脯スルモ朋楼原質量二著變ナキタ述ベタリ。

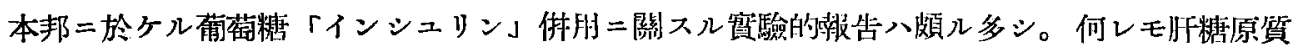

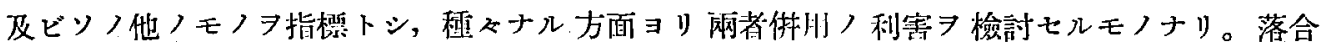

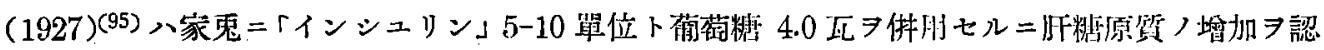

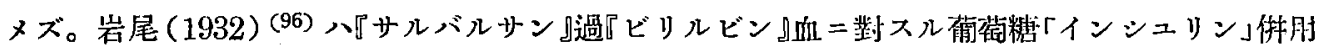
ヨ犬二就キ實驗七ル

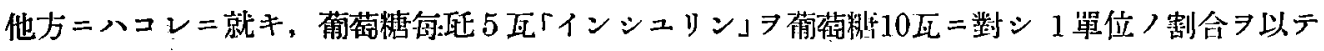

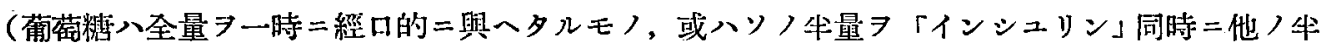
量 71 時間後經口的二)投與セル $=4$ 對二於テ 何レモ處嘕犬ガ血中『ビリルビン』量八小ナ ルコトヨ認メタリ。

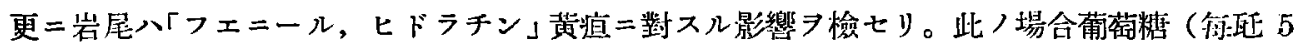

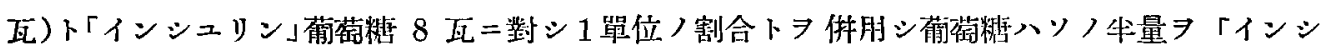
ユリン」注射卜同時ニ, 殘リ牛量八更二 1 時間媵二經口的二投與七リ。而シデ血精量ガ正常二復

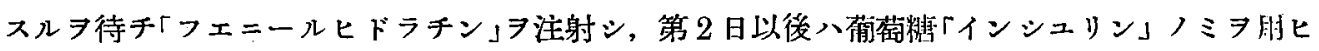

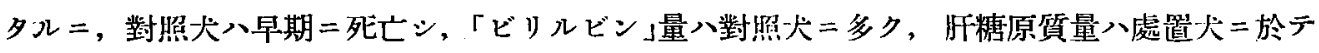
大ナリシト云フ。

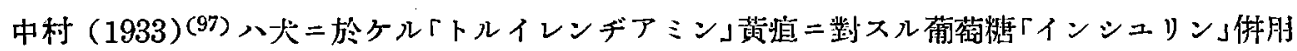
ノ影響

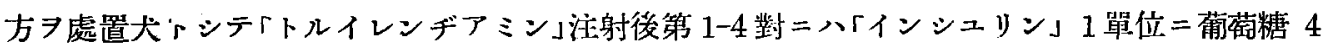
瓦ノ割合二加ヘシニ, 處置犬二於テハ「ビリルビン」ハ嚾少ニシテ, 旰糖原質八反對二多量ナリ

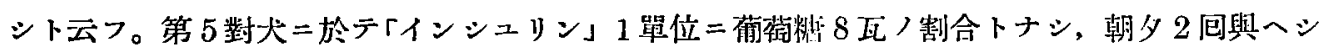
二, 血淸「ビリルビン」ハ對照犬卜ノ間二大差ナク朋糖原質八處置犬二多カリシト。第 6-9對=

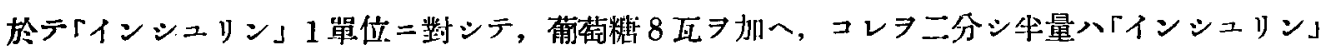
注射直後 $=$, 他ノ牛量八 1 時間後 $=$ 加へタル 著シク大, 1 例二於テハ對照犬卜差ナク，他ノ 2 例二於デ對热ノ方ガ大ニシテ，朋糖原質八 等シク處置犬ノ方大ナリシト云フ。

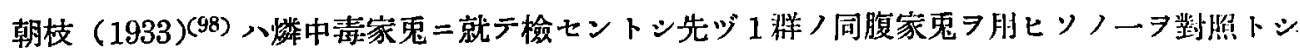

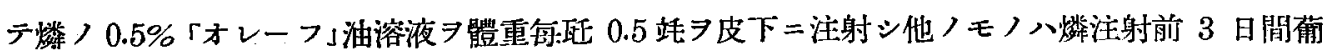

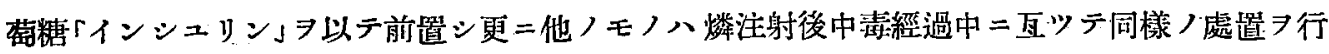
ヘリ。此/場合「インシュリン」ハ 1 單位トシテ皮下二注射シ，コレ二對シ $25 \%$ 葡萄糖溶液》 1 


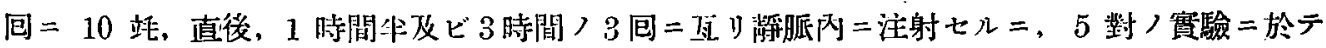
生存期閒八單獨燐投與家鬼最モ短ク，前處笾犬八之二次ギ，同時的處置犬八最モ長ク，肝，筋 肉，糖原質八之二一致シテ，同時的處足ノモノ二是モ多ク，單獨燐投與犬二於テ最モ少ナカリ

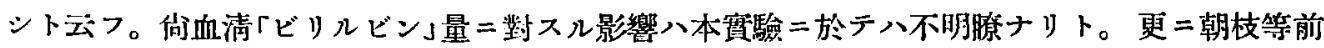

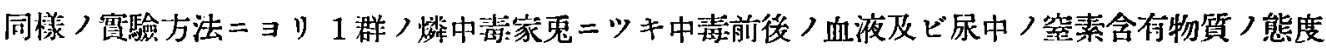

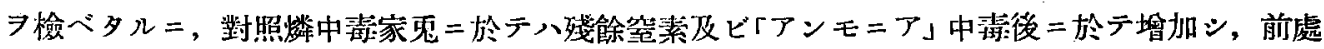

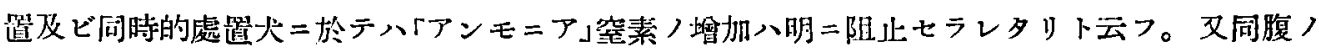
家鬼群ニ於テソノ一ヨ對照トシ，他ノ一二葡䔩糖

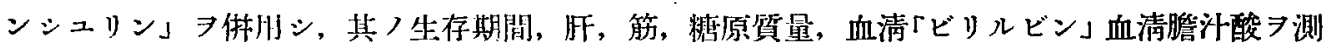

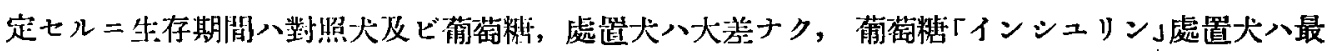

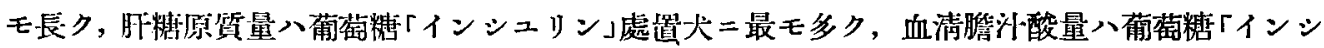
ユリン」處置ノモノ：最モ少ク，葡缺䌅處置犬二最モ多ク，血清「ビリルビン」八血清膽汒酸ノ 場合ト同一ナリシト云つ。藤原 $(1933)^{(99)}$ 八家鬼ニ「メントール」ア投與シ，葡萄糖，單獨投與

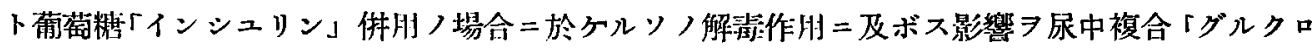
ン」酸タ指㯲トシテ觀察セリ。

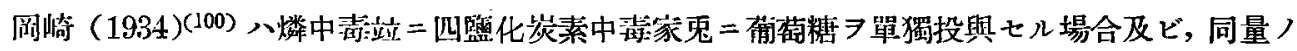

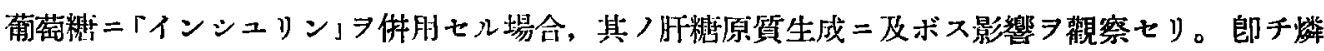

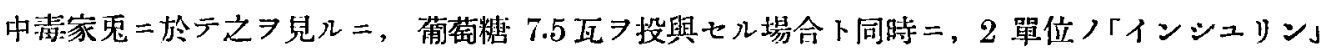

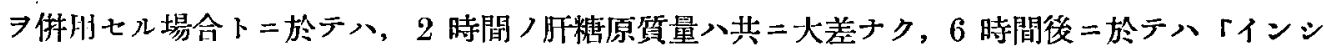
ユリン」ヨ件湖七ル時ハ却ツテ肝糖原質量ハ小トナリ。次デ「インシュリン」1單位注射後同量

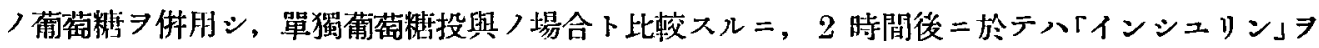

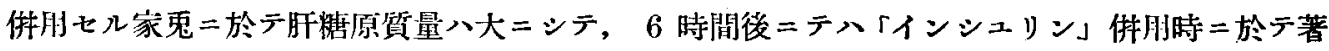

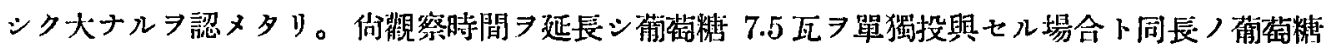

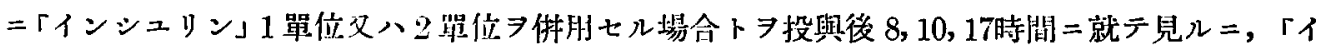

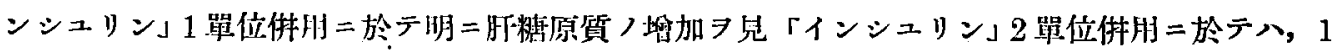

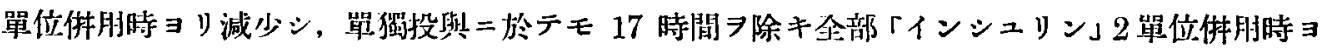

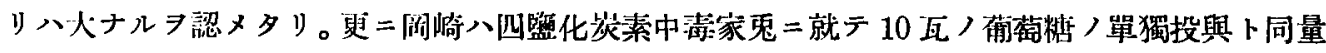

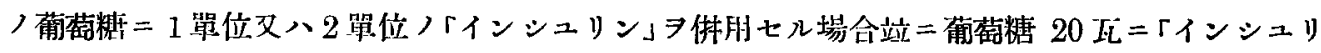

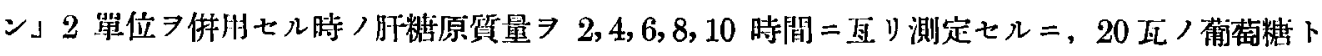
2 單位ノ「インシュリン」トヨ肞ヒタル時二於ケル肝糖原質つ增加八10瓦ノ葡萄糖卜 2 單位， 「インシュリン」トヨ件䏮セルトキヨリ少シク大ナレドモ, 10 瓦ノ葡萄糖ト 1 單位ノ「インシニ

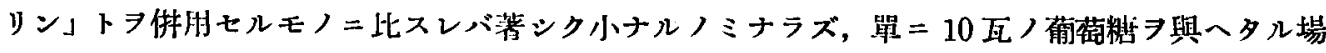

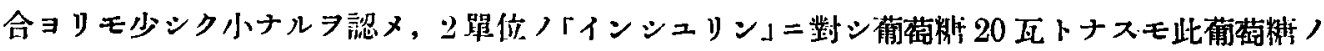


增量ハ過剩ノ「インシュリン」ノ侑害作刵 ヨ抑泚シ得ザルガ如シト云へリ。

山冈 $(1935)^{(101)}$ ハ「レチチン」乳化液注射家鬼＝對シ，單獨, 葡萄糖投與卜葡葫「インシュリン」

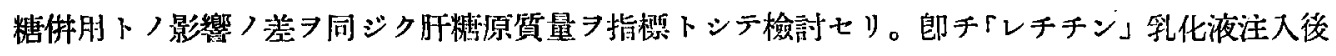

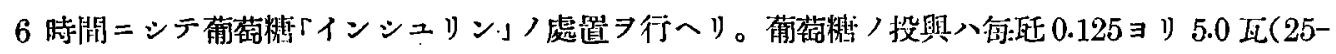

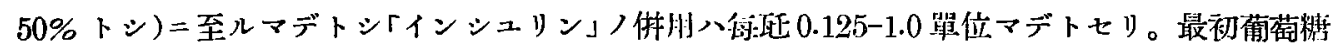
量ヨ一定トシ,「インシユリン」量ヨ種々變更シ, 炏デ「インシュリン」量ヨー定トシ, 葡萄糖

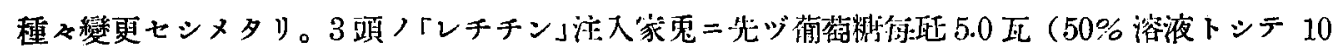

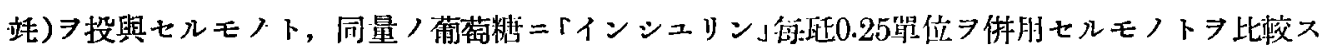

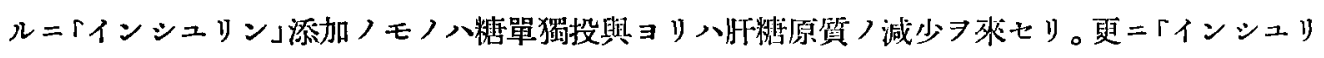

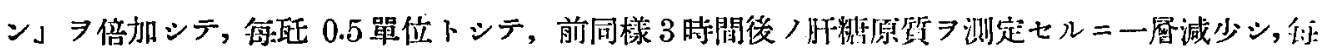

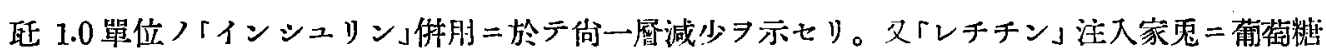

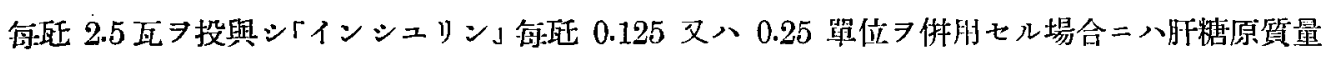

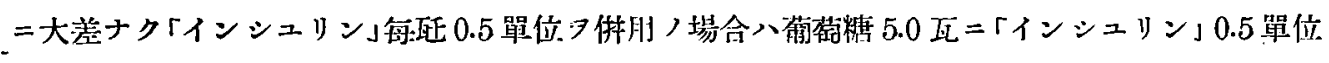

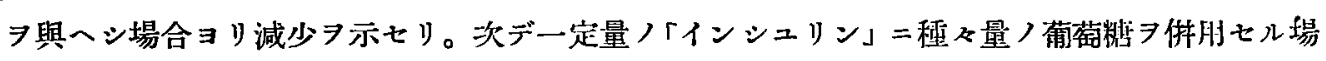

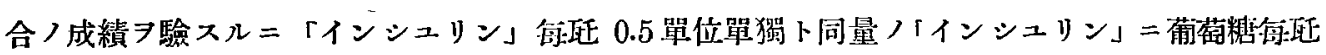

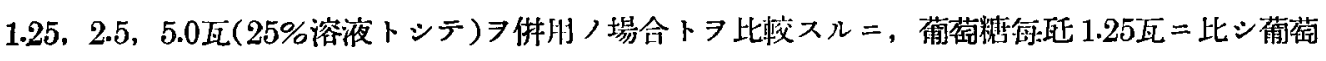

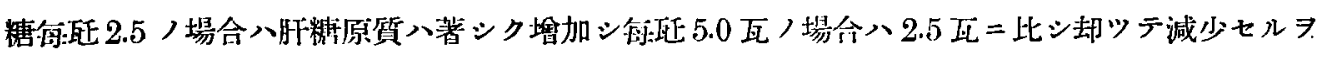

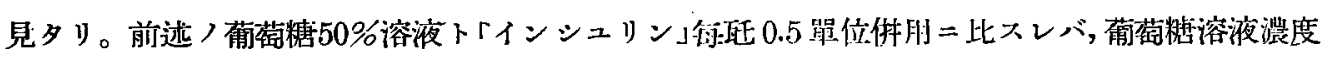

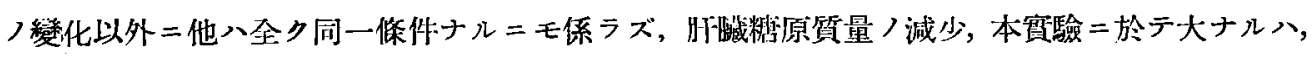

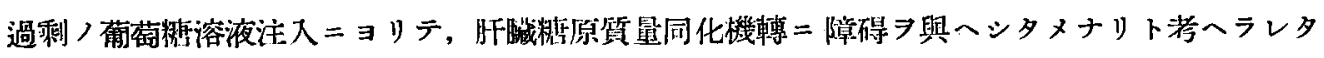

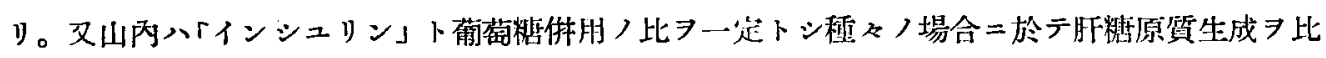

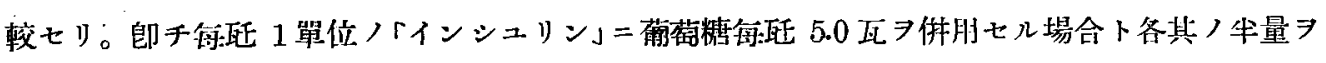

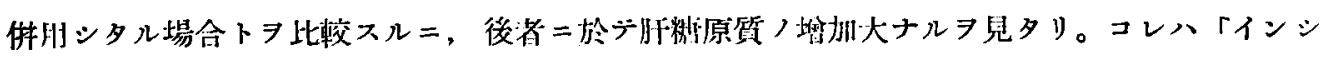

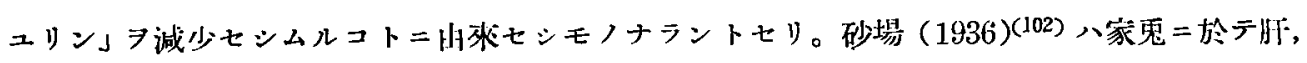
筋, 試驗片剔出後 2 時閒

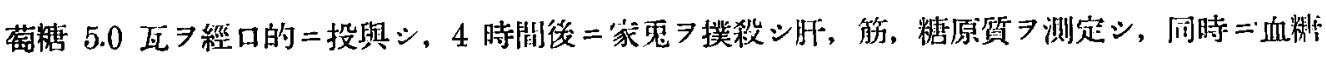

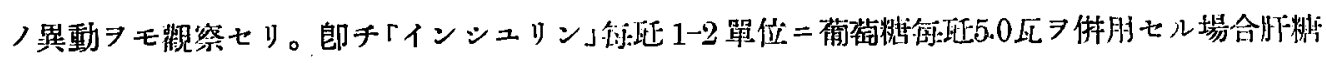
原質減少シ筋糖質量八堵加七ルラ゙認メタリ。而シテイインシュリン」大量投與八葡萄糖投與後〉

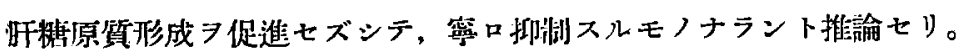

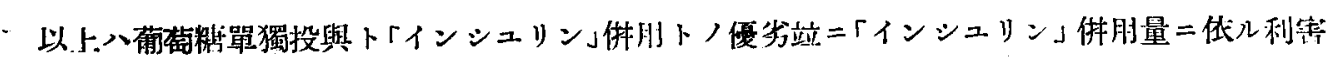

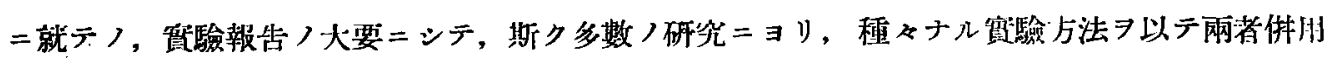
ノ效果二就キ追焱七ラレタルモ，来ダソノ效果二關シテ八諸家ノ說一致セザルモノアリ。

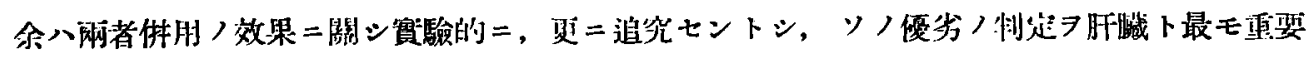




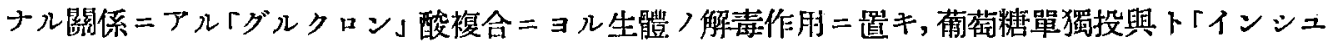

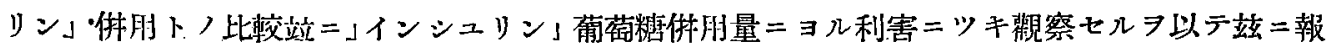

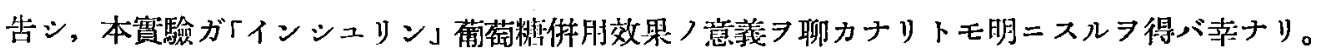

\section{第 2 章 實 驗 方 法}

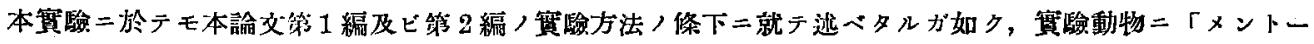

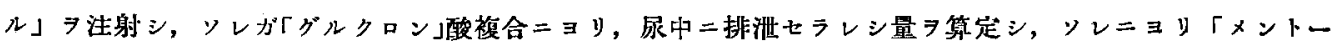

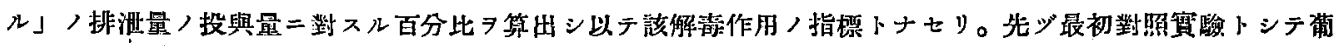

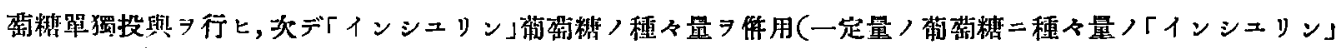

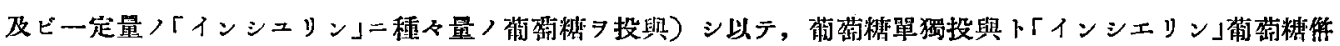

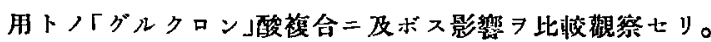

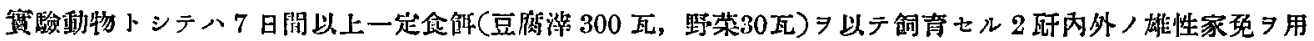
フ。實噞當日ハ絶食トナス。「カテーテル」ニテ排尿セル後體重ヨ計り筫驗終了マデハ探尿二便ナル檻ニテ安 青獎態习保タシム。

「メントール」ハ2瓦７5洭ノ「オレーフ」油二溶解シテ, 僅二加溫, 家鬼背部 /皮下二注射セリ。「メントー

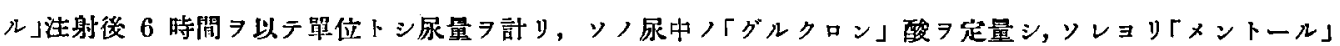

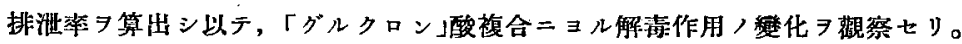

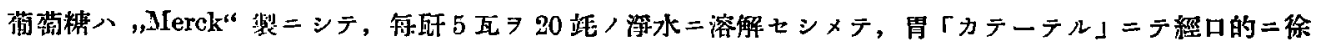
々ニ盟內二泩入七り。

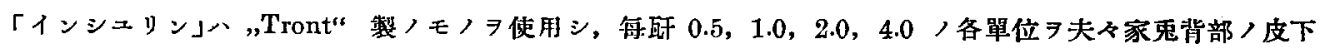
二注射七り。

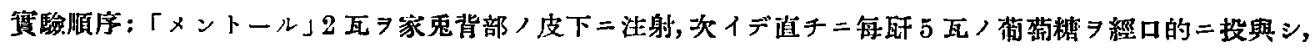

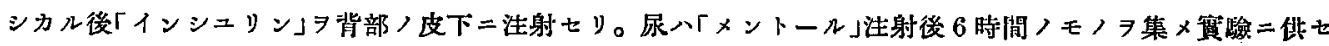

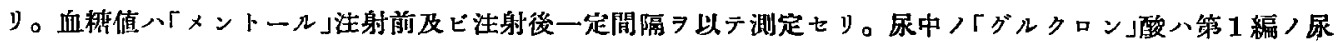
中ノ「グルクロン」酸定量法／條下二述ベタルガ如ク，A.J. Quick 法二ヨり测定せり。「メントール」/排泟

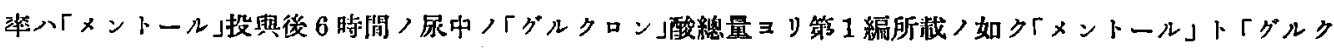

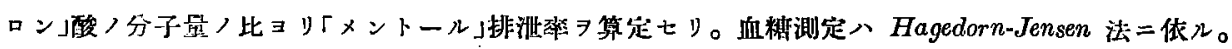

\section{第 3 章 實 驗 成 績}

\section{第 1 節 葡萄糖(毎迁 5 瓦)單獨投與ノ場合ノ「メントール}

\section{ノ排泄率及ビ血糖量（對照實驗）}

余入葡萄糖「インシュリン」件用ノ場合＝於ろル「メントール」排泄率ヨリ生體ノ「グルクロン」

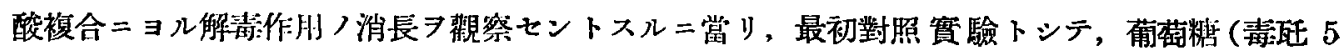

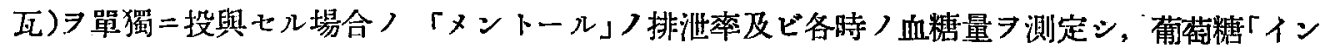

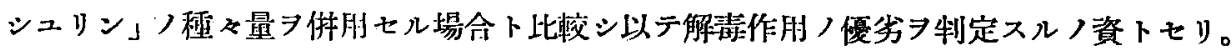

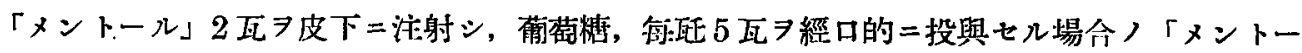


ル」排洲率入第 2 表 (其ノ1) =示スガ如ク 9.8-17.5\% ニシテソノ本均排洲率入 $12.2 \%$ ナリ。 第 2 表(其) 1 )參照

第 2 表 (其) 1 )

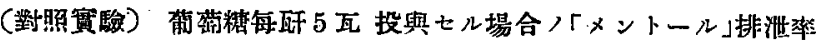

\begin{tabular}{|c|c|c|c|c|c|c|c|}
\hline $\begin{array}{l}\text { 實驗 } \\
\text { 例數 }\end{array}$ & 菑驗期日 & $\begin{array}{c}\text { 家患體重 } \\
\text { (䣶) }\end{array}$ & 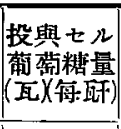 & 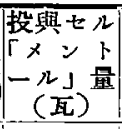 & 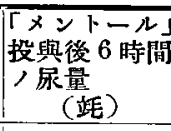 & 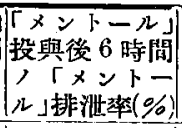 & 考 \\
\hline $\begin{array}{l}\text { I } \\
\text { III } \\
\text { III } \\
\text { IV } \\
\text { V } \\
\text { VI } \\
\text { VII }\end{array}$ & $\begin{array}{l}27 / \mathrm{IV} \\
18 / \mathrm{V} \\
20 / \mathrm{V} \\
22 / \mathrm{V} \\
17 / \mathrm{VI} \\
22 / \mathrm{VI} \\
25 / \mathrm{VI}\end{array}$ & $\begin{array}{l}1.600 \\
2.200 \\
1.700 \\
1.800 \\
1.830 \\
2.000 \\
2.150\end{array}$ & $\begin{array}{l}\mathbf{5 . 0} \\
5.0 \\
5.0 \\
5.0 \\
5.0 \\
5.0 \\
\mathbf{5 . 0}\end{array}$ & $\begin{array}{l}2.0 \\
2.0 \\
2.0 \\
2.0 \\
2.0 \\
2.0 \\
2.0\end{array}$ & $\begin{array}{l}20 \\
30 \\
54 \\
\mathbf{4 2} \\
\mathbf{5 5} \\
68 \\
\mathbf{4 2}\end{array}$ & $\begin{array}{r}9.8 \\
11.7 \\
17.5 \\
13.6 \\
8.8 \\
11.3 \\
12.4\end{array}$ & \multirow{2}{*}{ 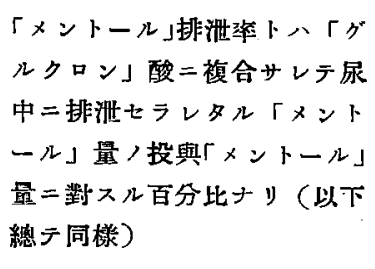 } \\
\hline \multicolumn{6}{|c|}{ 「メントール」本均排洲策\% } & 12.2 & \\
\hline
\end{tabular}

此ノ場合二於ケル各時血糖量ノ異動ハ第 2 装(其ノ2)二示スガ如ク「メントール」葡萄糖投與

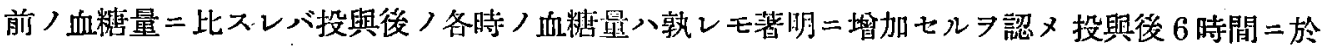
テモ投與前血糖量二復セザルョ見タリ。[第 2 表(其ノ 2 )參照]

第 2 表 (其, 2 )

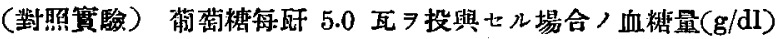

\begin{tabular}{|c|c|c|c|c|c|c|c|c|c|c|c|}
\hline \multicolumn{2}{|c|}{ 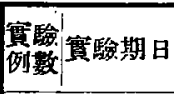 } & \multicolumn{2}{|c|}{ 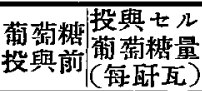 } & $\begin{array}{l}\text { 投與後 } \\
1 / 2 \text { 跱 }\end{array}$ & $\begin{array}{l}\text { 投與後 } \\
1.0 \text { (時) }\end{array}$ & $\begin{array}{c}\text { 投與後 } \\
11 / 2 \text { (時) }\end{array}$ & $\begin{array}{l}\text { 投與後 } \\
2.0 \text { (跱) }\end{array}$ & $\begin{array}{l}\text { 投與後 } \\
\text { 3.0(時) }\end{array}$ & $\begin{array}{l}\text { 投與啳 } \\
4.0 \text { (跱) }\end{array}$ & $\begin{array}{l}\text { 投與後 } \\
5.0 \text { (時) }\end{array}$ & $\begin{array}{l}\text { 投與後 } \\
6.0 \text { (時) }\end{array}$ \\
\hline I & $27 / I V$ & 0.095 & 5.0 & 0.215 & 0.274 & 0.300 & 0.274 & 0.270 & 0.148 & 0.125 & 0.093 \\
\hline & $18 / V$ & 0.113 & 5.0 & 0.161 & 0.195 & 0.224 & 0.272 & 0.278 & 0.191 & 0.152 & 0.125 \\
\hline & $20 / \mathrm{V}$ & 0.122 & 5.0 & 0.125 & 0.206 & 0.247 & 0.259 & 0.262 & 0.202 & 0.166 & 0.131 \\
\hline IV & $22 / V$ & 0.093 & 5.0 & 0.106 & 0.141 & 0.257 & 0.209 & 0.204 & 0.200 & 0.195 & 0.106 \\
\hline$\vec{V}$ & $1 i / \mathrm{VI}$ & 0.104 & 5.0 & 0.145 & 0.255 & 0.278 & 0.204 & 0.200 & 0.170 & 0.164 & 0.148 \\
\hline VI & $22 / \mathrm{VI}$ & 0.115 & 5.0 & 0.226 & 0.232 & 0.241 & 0.251 & 0.234 & 0.213 & 0.177 & 0.159 \\
\hline & $25 / V I$ & 0.112 & 5.0 & 0.136 & 0.184 & 0.234 & 0.182 & 0.166 & 0.152 & 0.117 & 0.113 \\
\hline 7 & ，均 & 0.107 & & 0.159 & 0.212 & 0.254 & 0.235 & 0.230 & 0.182 & 0.156 & 0.125 \\
\hline
\end{tabular}

\section{第 2 節 葡萄糖(毎迁 5 瓦)「インシユリン」(每毝 0.5 單位)}

\section{併用ノ場合ノ「メントール」排泄率及ビ血糖量}

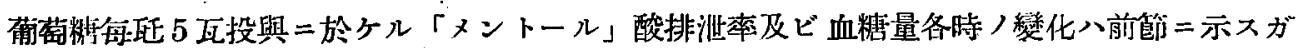

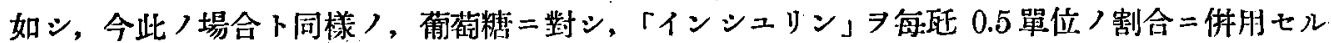
ニ「グルクロン」酸複合「メントール」ノ排淮率八第 3 表(其ノ 1 ) =示スガ如ク 10.4-21.1\%，ソ ノ本均ハ $16.4 \%$ トナレリ。之ア對照實驗ノ夫二比スル $=4.2 \%$ ノ增加 7 示セリ。第 3 表（其 (1)參照

此ノ場合ノ各例各時ノ血糖量ノ變化ハ第 3 表(其ノ 2 ) =示スガ如シ。之ヨ゙葡萄啸單獨投與實

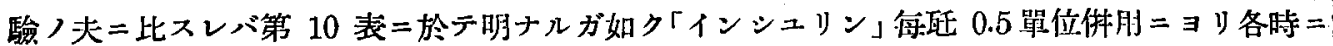

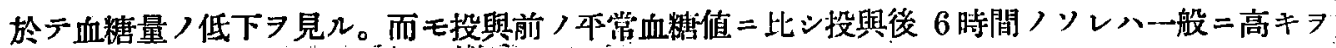


認ム。第 3 㳖(其) 2 )及ビ第 10 㤗參然

$$
\text { 第 } 3 \text { 表 (其, } 1 \text { ) }
$$

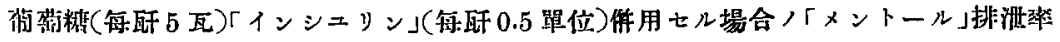

\begin{tabular}{|c|c|c|c|c|c|c|c|c|}
\hline $\begin{array}{l}\text { 被䠯 } \\
\text { 例數 }\end{array}$ & 菑䀰期日 & $\begin{array}{c}\text { 家鬼體重 } \\
\text { (酐) }\end{array}$ & 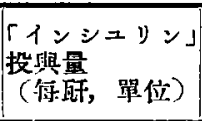 & 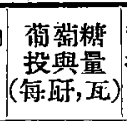 & $\begin{array}{l}\text { 「メントール」 } \\
\text { 投與量 } \\
\text { (瓦) }\end{array}$ & 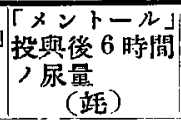 & 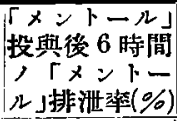 & 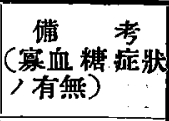 \\
\hline $\begin{array}{l}\text { I } \\
\text { III } \\
\text { III } \\
\text { IV } \\
\text { V } \\
\text { VI } \\
\text { VI }\end{array}$ & $\begin{array}{c}22 / \mathrm{IV} \\
29 / \mathrm{IV} \\
1 / \mathrm{V} \\
9 / \mathrm{V} \\
16 / \mathrm{V} \\
1 / \mathrm{VI} \\
1 / \mathrm{VI}\end{array}$ & $\begin{array}{l}1.650 \\
1.950 \\
1.900 \\
\mathbf{3 . 1 0 0} \\
1.950 \\
1.950 \\
\mathbf{2 . 0 5 0}\end{array}$ & $\begin{array}{l}0.5 \\
0.5 \\
0.5 \\
0.5 \\
0.5 \\
0.5 \\
0.5\end{array}$ & $\begin{array}{l}5.0 \\
5.0 \\
5.0 \\
5.0 \\
5.0 \\
5.0 \\
5.0\end{array}$ & $\begin{array}{l}2.0 \\
2.0 \\
2.0 \\
2.0 \\
2.0 \\
2.0 \\
2.0\end{array}$ & $\begin{array}{l}\mathbf{6 2} \\
\mathbf{3 5} \\
46 \\
40 \\
47 \\
\mathbf{3 5} \\
16\end{array}$ & \begin{tabular}{l|}
13.2 \\
21.1 \\
19.4 \\
20.3 \\
15.3 \\
15.0 \\
10.4
\end{tabular} & $\begin{array}{c}+z \\
\prime \prime \\
\prime \prime \\
\prime \prime \\
\prime \prime \\
\prime \prime \\
\prime \prime\end{array}$ \\
\hline \multicolumn{7}{|c|}{ メントール本均排使䇣 } & 16.4 & \\
\hline
\end{tabular}

$$
\text { 第 } 3 \text { 表 (其, } 2 \text { ) }
$$

\begin{tabular}{|c|c|c|c|c|c|c|c|c|c|c|c|}
\hline 筫醶 & 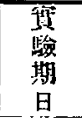 & 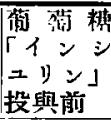 & 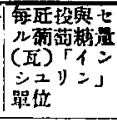 & 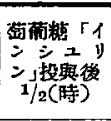 & $1.0(")$ & $11 / 2$ (時) & $\begin{array}{c}\prime \prime \\
2.0(\prime \prime)\end{array}$ & $3.0(1 ")$ & $4.0(11)$ & $\begin{array}{c}\prime \prime \\
5.0(" \prime)\end{array}$ & $6.0(1 /)$ \\
\hline I & $29 / \mathrm{IV}$ & 0.106 & 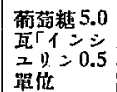 & 0.143 & 0.172 & 0.208 & 0.232 & 0.204 & 0.186 & 0.172 & 0.141 \\
\hline II & $29 / \mathbf{I V}$ & 0.097 & ", & 0.141 & .0 .190 & 0.131 & 0.127 & 0.119 & $0.09 \overline{5}$ & 0.092 & 0.090 \\
\hline III & $1 / V$ & 0.102 & ", & 0.146 & 0.152 & 0.184 & 0.188 & 0.152 & 0.125 & 0.108 & 0.102 \\
\hline IV & $9 / \mathrm{V}$ & 0.110 & ", & 0.170 & 0.200 & 0.208 & 0.232 & 0.236 & 0.197 & 0.161 & 0.108 \\
\hline$V$ & $16 / \mathrm{V}$ & 0.098 & ", & 0.108 & 0.119 & 0.125 & 0.139 & 0.136 & 0.120 & 0.117 & 0.099 \\
\hline VI & 1/VI & 0.106 & ", & 0.136 & 0.145 & 0.175 & 0.181 & 0.148 & 0.145 & 0.138 & 0.134 \\
\hline & 1/VI & 0.100 & ", & 0.143 & 0.152 & 0.161 & 0.166 & 0.173 & 0.161 & 0.152 & 0.131 \\
\hline 平 & 均 & 0.102 & & 0.141 & 0.161 & 0.170 & 0.180 & 0.166 & 0.147 & 0.134 & 0.115 \\
\hline
\end{tabular}

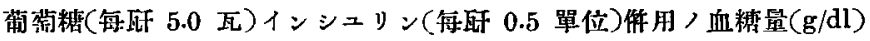

第 3 節 葡萄糖(每皕 5 瓦)「インシユリン」（毎迁 1,0單位)

\section{併用ノ場合ノ「メントール」排泄率及ビ血糖量}

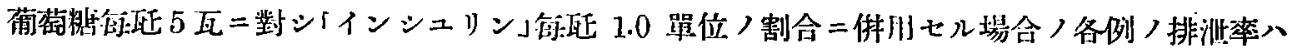

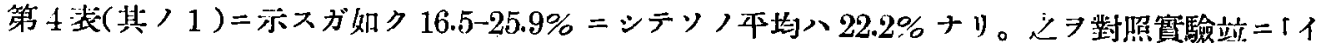

$$
\text { 第 } 4 \text { 裴 (其 }, 1 \text { ) }
$$

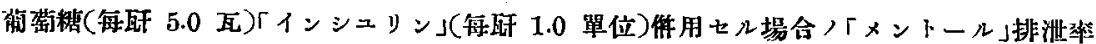

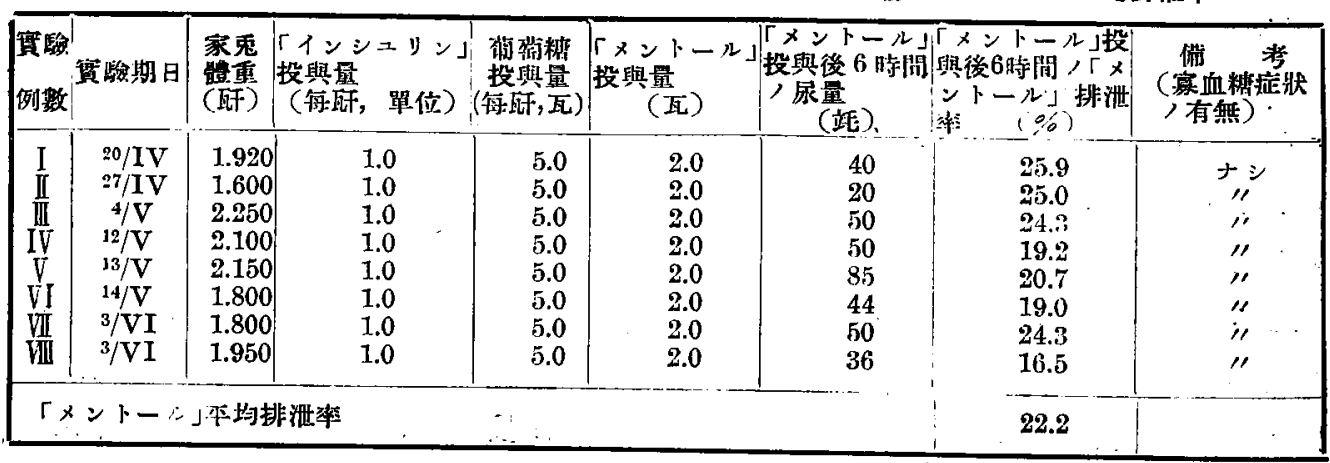




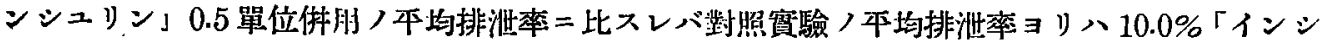

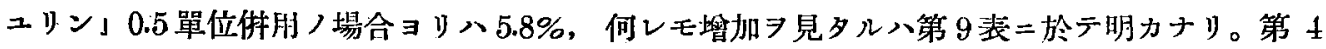
表(其ノ1)叉ビ第 9 表參照

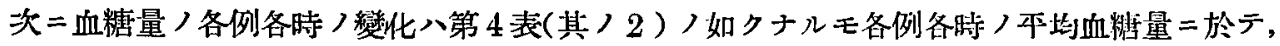

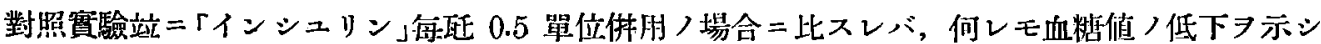
且ツ投與前ノ血糖量卜投與後 6 時間ノ血糖量八稍然シキヨ見ル，ソノ咩納ハ第 10 表二示スガ 如シ。【第 4 表(其ノ 2 )及第 10 表參照]

第 4 表 (其) 2 )

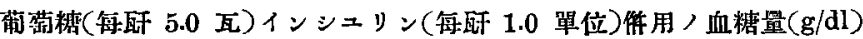

\begin{tabular}{|c|c|c|c|c|c|c|c|c|c|c|c|}
\hline 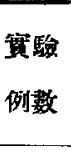 & 㖟驗期日 & 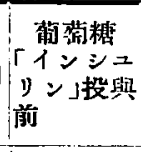 & 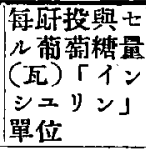 & 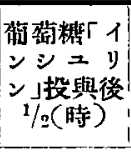 & $1.0 c^{\prime \prime}$ & $11 / 2(11)$ & $2.0(11)$ & $\begin{array}{c}\prime \prime \\
3.0(\prime \prime)\end{array}$ & $\begin{array}{c}\prime \prime \\
4.0(1)\end{array}$ & $\begin{array}{c}\prime \prime \\
5.0(")\end{array}$ & $\begin{array}{c}\prime \prime \\
6.0(" \prime)\end{array}$ \\
\hline I & $20 / 1 \mathrm{~V}$ & 0.105 & 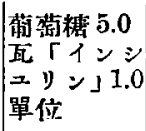 & 0.120 & 0.150 & 0.186 & 0.205 & 0.186 & 0.165 & $0.14^{2}$ & 0.125 \\
\hline II & $\begin{array}{c}27 / 1 \mathrm{~V} \\
4 / \mathrm{V}\end{array}$ & $\begin{array}{l}0.110 \\
0.099\end{array}$ & $"$ & $\begin{array}{l}0.119 \\
0.115\end{array}$ & $\begin{array}{l}0.146 \\
0.159\end{array}$ & $\begin{array}{l}0.177 \\
0.186\end{array}$ & $\begin{array}{l}0.184 \\
0.209\end{array}$ & $\begin{array}{l}0.177 \\
0.208\end{array}$ & $\begin{array}{l}0.122 \\
0.182\end{array}$ & $\begin{array}{l}0.101 \\
0.154\end{array}$ & $\begin{array}{l}0.095 \\
0.138\end{array}$ \\
\hline IV & $12 / V$ & 0.112 & " & 0.146 & 0.164 & 0.157 & 0.138 & 0.106 & 0.088 & 0.079 & 0.075 \\
\hline & $13 / V$ & 0.106 & $"$ & 0.120 & 0.182 & 0.197 & 0.190 & 0.168 & 0.125 & 0.115 & 0.110 \\
\hline II & $14 / \mathrm{V}$ & 0.110 & ", & 0.164 & 0.138 & 0.124 & 0.106 & 0.088 & 0.079 & 0.075 & 0.074 \\
\hline VII & $3 / \mathrm{VI}$ & 0.083 & ", & 0.099 & 0.1 .17 & 0.146 & 0.150 & 0.146 & 0.131 & 0.115 & 0.099 \\
\hline VIII & $3 / \mathrm{VI}$ & & $"$ & 0.134 & 0.161 & 0.164 & 0.168 & 0.164 & 0.152 & 0.148 & 0.138 \\
\hline 平 & 均 & 0.104 & & 0.127 & 0.152 & 0.167 & 0.168 & 0.154 & 0.130 & 0.116 & 0.106 \\
\hline
\end{tabular}

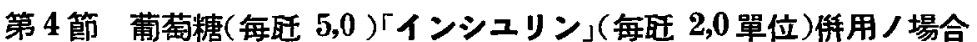

\section{ノ「メントール」排泄率及ビ血糖量}

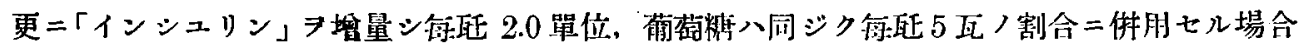

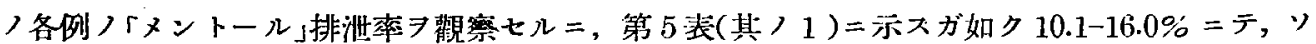

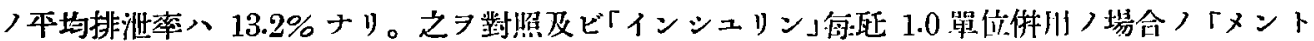

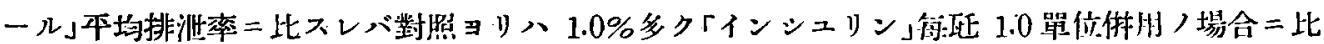

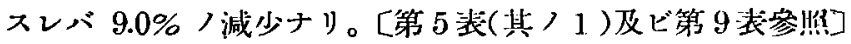

$$
\text { 第 } 5 \text { 老 (其, } 1 \text { ) }
$$

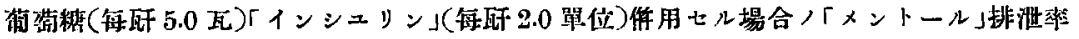

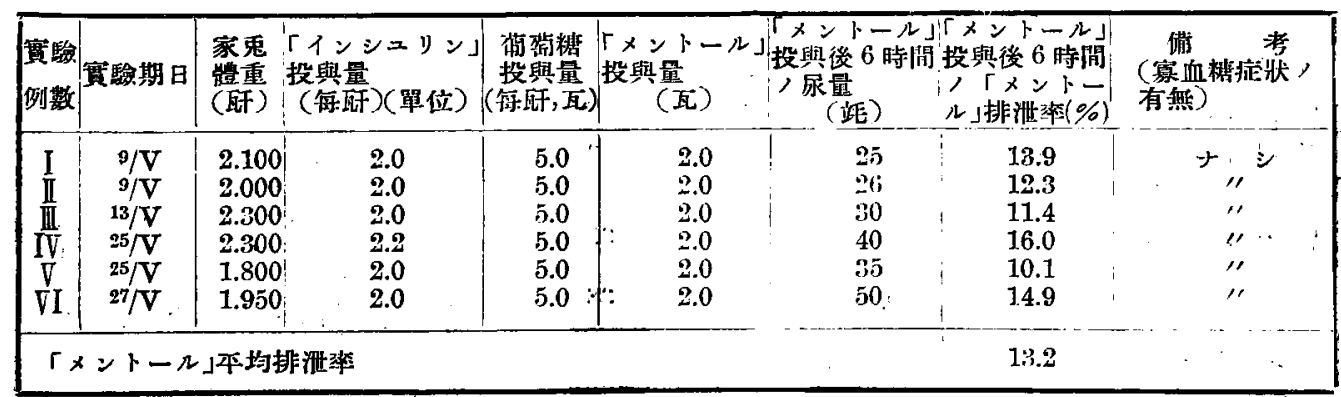




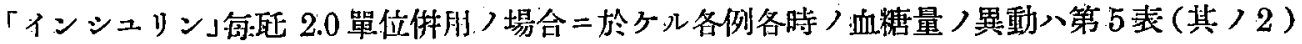

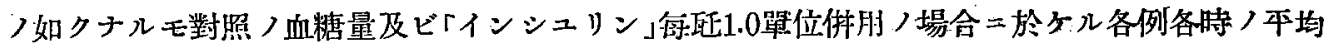
血糖量二比スレバ第 10 表二示スガ如ク對照本均血糖量 $コ$ 各時共二減少シ, 殊二 6 侍間後二於 テハ「ヌントール」葡萄糖等ノ投與前ヨリ低下七ルラ見タリ。

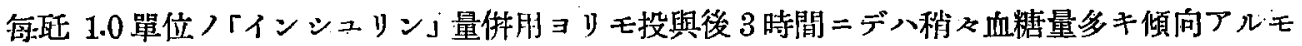
4 時間以後ニ於テハ却ツテ減少セり。第 5 表(其ノ 2 )及ビ第 10 裴參照

$$
\text { 第 } 5 \text { 表 (其) } 2 \text { ) }
$$

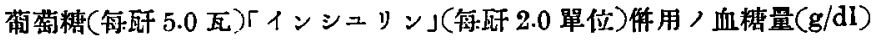

\begin{tabular}{|c|c|c|c|c|c|c|c|c|c|c|c|}
\hline $\begin{array}{l}\text { 暻驗 } \\
\text { 例数 }\end{array}$ & 實龭期日 & 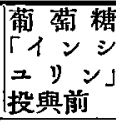 & 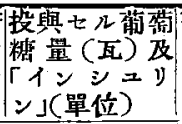 & 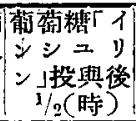 & $1.0(" \prime)$ & $\begin{array}{c}\prime \prime \\
11 / 2(" \prime)\end{array}$ & $2.0(1)$ & $\begin{array}{c}1 \prime \\
3.0(11)\end{array}$ & $\begin{array}{c}\prime \prime \\
4.0(\prime \prime)\end{array}$ & $\begin{array}{c}\prime \prime \\
5.0 l^{\prime \prime}\end{array}$ & $6.0(\prime \prime)$ \\
\hline I & $29 / I V$ & 0.110 & 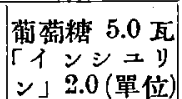 & 0.161 & 0.179 & 0.184 & 0.191 & 0.172 & 0.115 & 0.110 & 0.095 \\
\hline II & $9 / \mathrm{V}$ & 0.113 & $n$ & 0.152 & 0.215 & 0.213 & 0.163 & 0.148 & 0.139 & 0.136 & 0.129 \\
\hline 而 & $13 / \mathrm{V}$ & 0.093 & ", & 0.136 & 0.230 & 0.200 & 0.159 & 0.132 & 0.112 & 0.079 & 0.075 \\
\hline IV & $25 / \mathrm{V}$ & 0.113 & , & 0.124 & 0.134 & 0.138 & 0.131 & 0.127 & 0.110 & 0.101 & 0.097 \\
\hline$V$ & $25 / \mathrm{V}$ & 0.092 & ", & 0.136 & 0.175 & 0.188 & 0.193 & 0.186 & 0.095 & 0.074 & 0.070 \\
\hline VI & $27 / \mathrm{V}$ & 0.102 & " & 0.131 & 0.179 & 0.222 & 0.188 & 0.181 & 0.148 & 0.127 & 0.106 \\
\hline & 均 & 0.103 & & 0.140 & 0.185 & 0.195 & 0.170 & 0.157 & 0.119 & 0.104 & 0.095 \\
\hline
\end{tabular}

\section{第 5 節 葡萄糖(每聒 5 瓦)「インシュリン」(每㮩 4.0 單位)}

\section{俆用ノ場合ノ「メントール」排泄率及ビ血糖量}

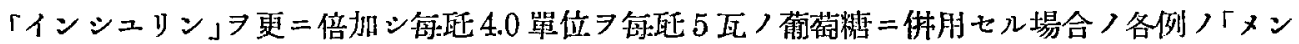
トール」排泄率八第 6 表(其ノ1) =示スガ如ク 6.4-12.3\% ニシテソノ本均排泄率八10.3\%ナリ。

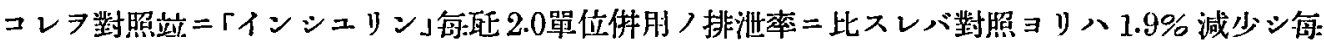

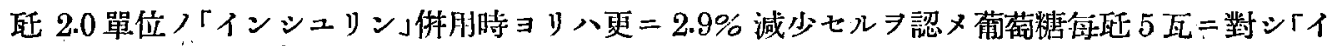

$$
\text { 第 } 6 \text { 表 (其 } 1 \text { ) }
$$

\begin{tabular}{|c|c|c|c|c|c|c|c|c|}
\hline 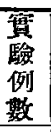 & $\begin{array}{l}\text { 窖 } \\
\text { 聽 } \\
\text { 㫷 } \\
\text { 日 }\end{array}$ & $\begin{array}{l}\text { 家勨 } \\
\text { 䯠重 } \\
\text { (刵) }\end{array}$ & 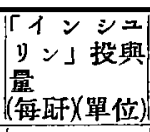 & 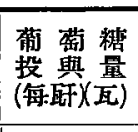 & 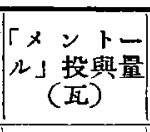 & 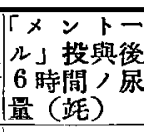 & 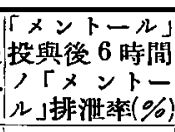 & $\begin{array}{c}\text { 借 } \\
\text { (腺血糖症狀，有無） }\end{array}$ \\
\hline I & $2 / \mathrm{VI}$ & 2.450 & 4.0 & 5.0 & 2.0 & 72 & 6.4 & $t$ \\
\hline II & $2 / \mathrm{VI}$ & 1.750 & 4.0 & 5.0 & 2.0 & 26 & 9.7 & " \\
\hline III & $7 / \mathrm{VI}$ & 1.830 & 4.0 & 5.0 & 2.0 & 34 & 10.0 & " \\
\hline IV & $10 / \mathrm{VII}$ & 1.800 & 4.0 & 5.0 & 2.0 & 37 . & 11.4 & 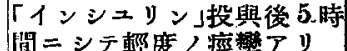 \\
\hline V & $11 / \mathrm{VII}$ & 1.800 & 4.0 & 5.0 & 2.0 & 40 & 10.6 & 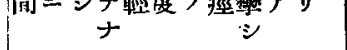 \\
\hline VI & $15 / \mathrm{VII}$ & 1.870 & 4.0 & 5.0 & 2.0 & 38 & 11.9 & ナ \\
\hline VII & $17 / \mathrm{VII}$ & 1.800 & 4.0 & 5.0 & 2.0 & 33 & 10.9 & 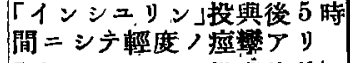 \\
\hline VIII & $19 / \mathrm{VII}$ & 1.750 & 4.0 & 5,0 & 2.0 & 38 & 12.3 & 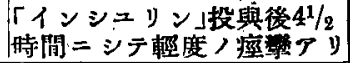 \\
\hline \multicolumn{7}{|c|}{ 「メントール」平均排湛來 } & 10.3 & $\ldots$ \\
\hline
\end{tabular}

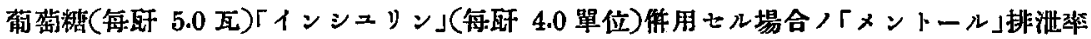




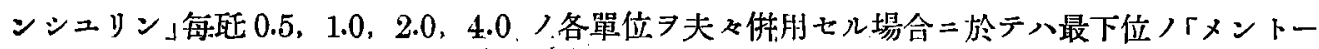
ル排泄率トナルコト入第 9 表ニ於テ明ナリ。第 6 表(其) 1 )及ビ第 9 表參照

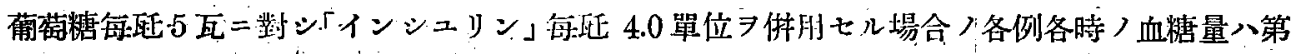

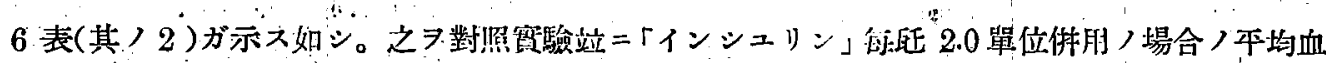

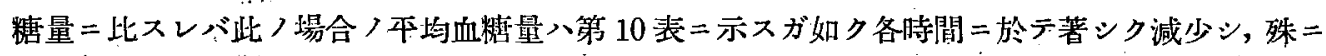
投與後 3 時間以後/血糖量入投與前/血糖量ヨリ著シク低下セルラ認ム', 實驗例数 8 例中內 3

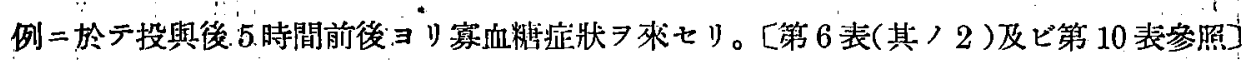

第 6 表 (其, 2 )

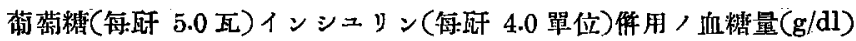

\begin{tabular}{|c|c|c|c|c|c|c|c|c|c|c|c|}
\hline 例数 & 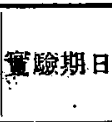 & 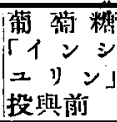 & 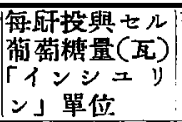 & 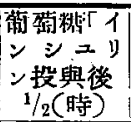 & $\begin{array}{c}\prime \prime \\
1.0(\prime \prime)\end{array}$ & $11 / 2(1 \prime)$ & $2.0(1 /)$ & $\begin{array}{c}\prime \prime \\
3.0(\prime \prime)\end{array}$ & $4.0(1 \prime)$ & $\begin{array}{c}\prime \prime \\
\vdots 2 \\
5.0(\prime \prime)\end{array}$ & $6.01^{\prime \prime}$ \\
\hline & $2 / \mathrm{VI}$ & 0.108 & 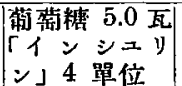 & 0.120 & 0.146 & 0.138 & 0.095 & 0.092 & 0.075 & 0.052 & 0.050 \\
\hline II & $2 / \mathrm{VI}$ & 0.101 & " & 0.132 & 0.181 & 0.177 & 0.159 & 0.102 & 0.088 & 0.068 & 0.065 \\
\hline III & $7 / \mathrm{VI}$ & 0.111 & 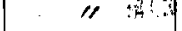 & 0.113 & 0.117 & 0.120 & 0.119 & 0.095 & 0.084 & 0.057 & 0.047 \\
\hline IV & $10 / \mathrm{VII}$ & 0.115 & $\| \rightarrow$ & 0.164 & 0.174 & 0.117 & 0.115 & 0.110 & 0.108 & 0.101 & 0.097 \\
\hline$V$ & $11 / \mathrm{VII}$ & 0.105 & "' & 0.120 & 0.134 & 0.155 & 0.125 & 0.092 & 0.084 & 0.061 & 0.054 \\
\hline VI & $15 / \mathrm{VII}$ & 0.110 & $" \prime$ & 0.125 & 0.108 & 0.099 & 0.088 & 0.074 & 0.070 & 0.066 & 0.050 \\
\hline VII & 17/VII & 0.102 & " & 0.129 & 0.110 & 0.106 & 0.088 & 0.061 & 0.057 & 0.052 & 0.050 \\
\hline VIII & $18 /$ VII & 0.099 & "I & 0.113 & 0.120 & 0.102 & 0.088 & 0.068 & 0.045 & 0.039 & 0.036 \\
\hline & 均 & 0.106 & & 0.127 & 0.136 & 0.126 & 0.109 & 0.086 & 0.076 & 0.062 & 0.056 \\
\hline
\end{tabular}

第 6 節，葡萄糖(每䣶 10.0瓦)「インシュリン」(每酕 1,0單位)

佯用ノ場合ノ「メントール」排泄率及ビ血糖量

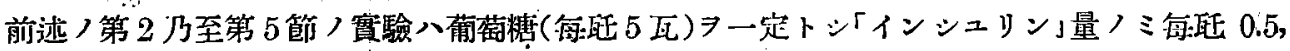

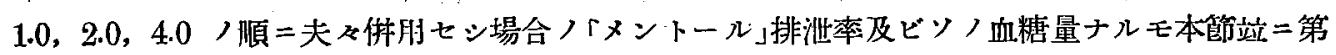

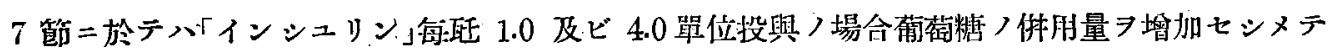
每艇 10.0 瓦トシ「メントール」ノ排泄率及ビ血絋量习觀察七り。

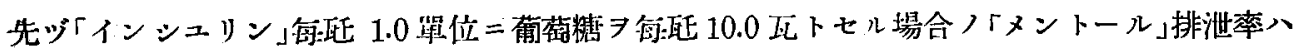
第 7 表(其ノ 1 ) =示スガ如ク 11.3-21.0\% ニシテソノ本均排沭率八 $16.6 \%$ ナリ。.コレア「イン

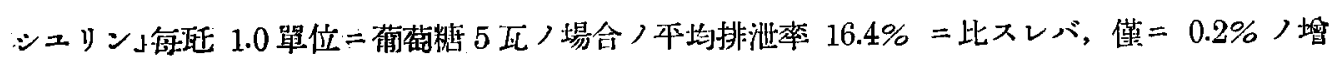
加ヨ見殆ド變化ナキ狀態ナリ。

$\therefore$ 此ノ場合ノ實驗成績习通覽スレバ或ル好適量ノ「インシンリン」ニ對シテハ過量ノ葡萄糖 與スルモ「メントール」ノ排泄率八第9表二於テ明ナルガ如ク增加スルモノニアナザルコトラ認 ×夕 J。[第 7 表(其ノ 1 )寥照]

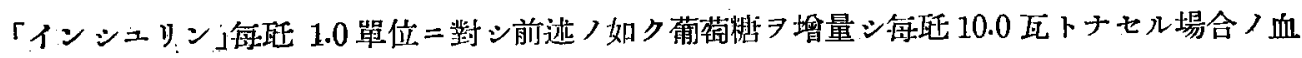

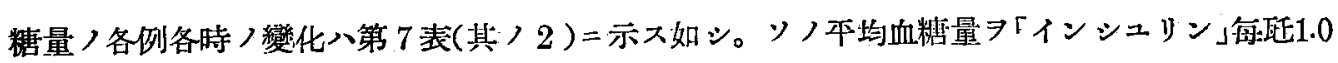

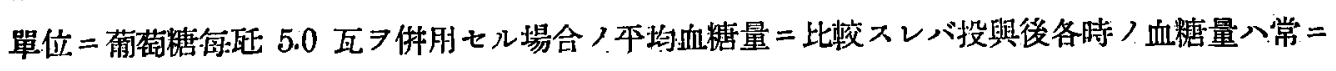


第 7 表 (其, 1 )

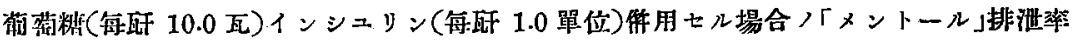

\begin{tabular}{|c|c|c|c|c|c|c|c|c|}
\hline $\begin{array}{l}\text { 實踆 } \\
\text { 例數 }\end{array}$ & 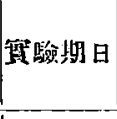 & 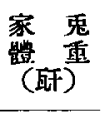 & 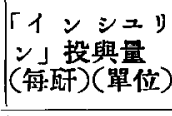 & 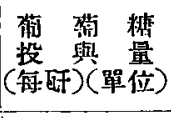 & 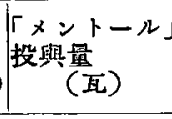 & 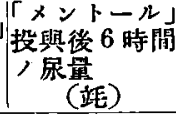 & 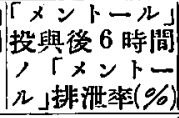 & 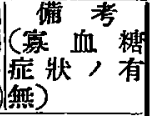 \\
\hline $\begin{array}{l}\text { I } \\
\text { III } \\
\text { IV } \\
\text { V } \\
\text { VI } \\
\text { VII }\end{array}$ & $\begin{array}{l}6 / \mathrm{VI} \\
9 / \mathrm{VI} \\
10 / \mathrm{VI} \\
10 / \mathrm{VI} \\
15 / \mathrm{VI} \\
15 / \mathrm{VI} \\
17 / \mathrm{VI}\end{array}$ & $\begin{array}{l}1.900 \\
1.900 \\
1.850 \\
1.950 \\
1.930 \\
1.950 \\
1.750\end{array}$ & $\begin{array}{l}1.0 \\
1.0 \\
1.0 \\
1.0 \\
1.0 \\
1.0 \\
1.0\end{array}$ & $\begin{array}{l}10.0 \\
10.0 \\
10.0 \\
10.0 \\
10.0 \\
10.0 \\
10.0\end{array}$ & $\begin{array}{l}2.0 \\
2.0 \\
2.0 \\
2.0 \\
2.0 \\
2.0 \\
\mathbf{3} .0\end{array}$ & $\begin{array}{l}62 \\
\mathbf{3 5} \\
\mathbf{3 5} \\
17 \\
\mathbf{2 7} \\
\mathbf{3 3} \\
\mathbf{3 5}\end{array}$ & $\begin{array}{l}18.5 \\
19.9 \\
21.0 \\
15.8 \\
19.4 \\
15.0 \\
11.3\end{array}$ & $\begin{array}{c}+11 \\
11 \\
11 \\
\prime \prime \\
11 \\
11\end{array}$ \\
\hline \multicolumn{7}{|c|}{ 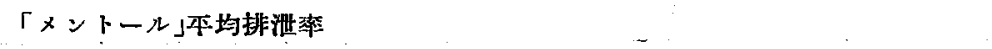 } & 16.6 & \\
\hline
\end{tabular}

多キフ見タルハ第 10 表二於テ明ナリ。且ツ投與前ノ血精量二比シ投與後.6時間ノ血糖量ハ著 シク上昇セル

第 7 表 (其) $\mathbf{2}$ )

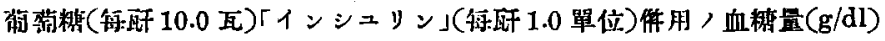

\begin{tabular}{|c|c|c|c|c|c|c|c|c|c|c|c|}
\hline 例數 & 實䀰期日 & 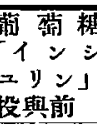 & 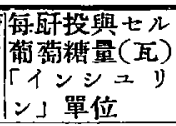 & 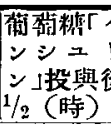 & $"$ & $11 / 2$ & & $\prime \prime$ & 4.0 & $\left.5.0 c^{\prime \prime}\right)$ & $.0(1)$ \\
\hline I & $6 / \mathrm{VI}$ & 0.097 & 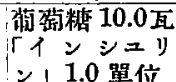 & 0.247 & $0.25 \overline{5}$ & 0.292 & 0.296 & 0.290 & 0.286 & 0.278 & 0.272 \\
\hline II & 9/VI & 0.111 & (1) & 0.199 & 0.211 & 0.195 & 0.168 & 0.159 & 0.150 & 0.146 & 0.143 \\
\hline III & $10 / \mathrm{VI}$ & 0.106 & "I & 0.177 & 0.195 & 0.199 & 0.166 & 0.155 & 0.152 & 0.146 & 0.138 \\
\hline IV & $10 / \mathrm{VI}$ & 0.097 & $\prime \prime$ & 0.173 & 0.204 & 0.236 & 0.247 & 0.241 & 0.232 & 0.228 & 0.219 \\
\hline$\vec{V}$ & $15 / \mathrm{VI}$ & 0.099 & "I & 0.164 & 0.190 & 0.245 & 0.232 & 0.208 & 0.195 & 0.190 & 0.181 \\
\hline VI & $15 / \mathrm{VI}$ & 0.124 & '" & 0.184 & 0.264 & 0.280 & 0.343 & 0.336 & 0.329 & 0.314 & 0.228 \\
\hline VII & $17 / \mathrm{VI}$ & 0.099 & "I & 0.190 & 0.222 & 0.232 & 0.236 & 0.249 & 0.124 & 0.092 & 0.088 \\
\hline & 均 & 0.104 & & 0.190 & 0.220 & 0.239 & 0.241 & 0.234 & 0.209 & 0.199 & 0.181 \\
\hline
\end{tabular}

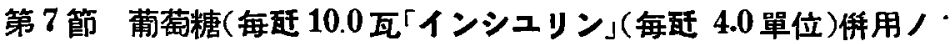

\section{場合ノ「メントール」排泄率及ビ血糖量}

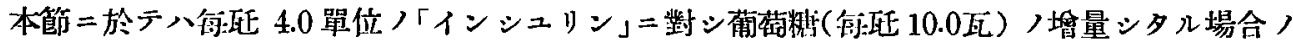
「メントール」ノ排淮率 7 見ル =第 8 表(其ノ1) =示スガ如ク 6.5-11.7\%ニシテソノ平均排沘率

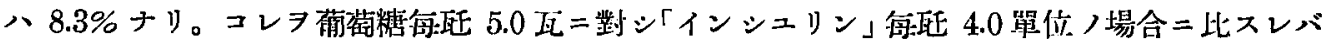
第 9 表二於テ归ナル如ク，ソノ平均排浛率二於テハ却ツテ $2.0 \%$ ノ減少

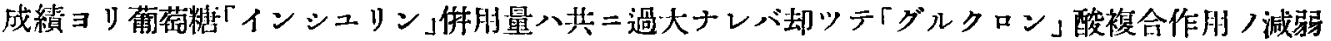

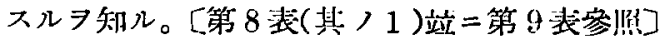

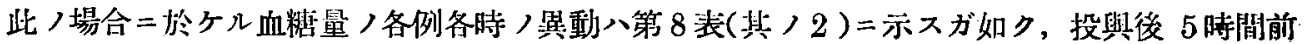

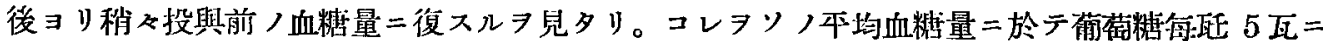

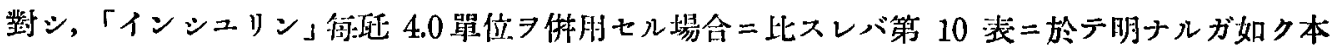

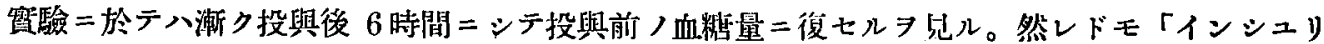




$$
\text { 第 } 8 \text { 表 (其) } 1 \text { ) }
$$

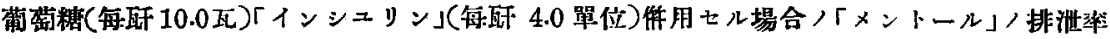

\begin{tabular}{|c|c|c|c|c|c|c|c|c|}
\hline $\begin{array}{l}\text { 賽驗 } \\
\text { 例數 }\end{array}$ & 實驗期日 & $\begin{array}{l}\text { 家 鬼 } \\
\text { 體 重 } \\
\text { (时) }\end{array}$ & 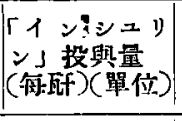 & 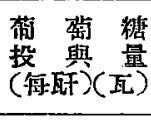 & 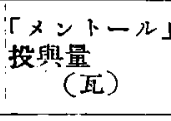 & 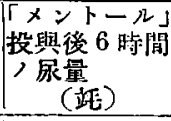 & 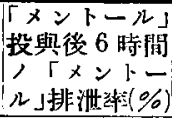 & $\begin{array}{c}\text { 借 考 } \\
\text { (察血糖瘤 } \\
\text { 狀，有無) }\end{array}$ \\
\hline I & 21/VI & 1.800 & 4.0 & 10.0 & 2.0 & 22 & 8.6 & ナ シ \\
\hline II & T/VII & 1.880 & 4.0 & 10.0 & 2.0 & 20 & 7.8 & II \\
\hline 荋 & 13/VII & 2.000 & 4.0 & 10.0 & 2.0 & 15 & 7.8 & $" \prime$ \\
\hline IV & $16 / \mathrm{VII}$ & 2.100 & 4.0 & 10.0 & 2.0 & 10 & 6.9 & "1 \\
\hline V & 16/VII & 1.750 & 4.0 & 10.0 & 2.0 & 15 & 6.5 & 11 \\
\hline I & $18 / \mathrm{VII}$ & 1.850 & 4.0 & 10.0 & 2.0 & 22 & 11.7 & 11. \\
\hline VI & 20/VII & 1.800 & 4.0 & 10.0 & 2.0 & 25 & 9.7 & 11 \\
\hline 惮 & ${ }^{22} / \mathrm{VII}$ & 2.100 & 4.0 & 10.0 & 2.0 & 12 & 7.8 & $" 1$ \\
\hline \multicolumn{7}{|c|}{ 「メントール」本均排泄率 } & 8.3 & \\
\hline
\end{tabular}

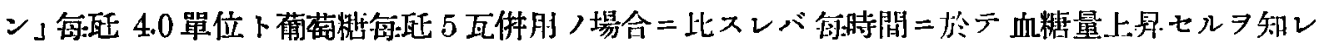
リ。第 8 表(其ノ 2 )代ビ第 10 装寥照

$$
\text { 第 } 8 \text { 表 (其, } 2 \text { ) }
$$

\begin{tabular}{|c|c|c|c|c|c|c|c|c|c|c|c|}
\hline $\begin{array}{l}\text { 箇駿 } \\
\text { 例数 }\end{array}$ & 䔈驗期日 & 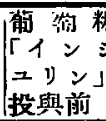 & 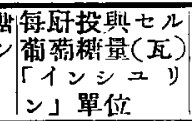 & 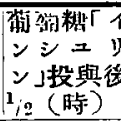 & $1.0(1 /)$ & $1 / 2 C$ & $2.0\left(^{\prime \prime}\right.$ & $3.0\left({ }^{\prime \prime}\right)$ & $4.0 C$ & $5.0 c^{\prime \prime}$ & $6.0(11)$ \\
\hline I & $21 / \mathrm{V}$ & 0.115 & 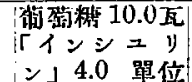 & 0.134 & 0.188 & 0.132 & 0.124 & 0.115 & 0.110 & 0.106 & 0.079 \\
\hline II & $0 / \mathrm{VII}$ & 0.095 & I & 0.124 & 0.189 & 0.131 & 0.125 & 0.122 & 0.110 & 0.106 & 0.090 \\
\hline III & $13 /$ VII & 0.090 & $" \prime$ & 0.132 & 0.152 & 0.157 & 0.211 & 0.157 & 0.152 & 0.131 & 0.125 \\
\hline IIV & 16/VII & 0.075 & "I & 0.219 & 0.206 & 0.191 & 0.141 & 0.132 & 0.115 & 0.106 & 0.092 \\
\hline y & $16 / \mathrm{VII}$ & 0.088 & $\prime \prime$ & 0.132 & 0.154 & 0.195 & 0.150 & 0.129 & 0.119 & 0.104 & 0.084 \\
\hline 5 & 18/VII & 0.138 & " & 0.173 & 0.200 & 0.197 & 0.191 & 0.146 & 0.141 & 0.120 & 0.117 \\
\hline & $20 / \mathrm{VII}$ & 0.141 & $\prime \prime$ & 0.157 & 0.143 & 0.138 & 0.131 & 0.125 & 0.128 & 0.120 & 0.117 \\
\hline & ${ }^{22} / \mathrm{VII}$ & 0.117 & $\prime \prime$ & 0.204 & 0.213 & 0.228 & 0.197 & 0.140 & 0.115 & 0.106 & 0.097 \\
\hline 平 & 均 & 0.107 & & 0.159 & 0.168 & 0.171 & 0.158 & 0.193 & 0.123 & 0.112 & 0.100 \\
\hline
\end{tabular}

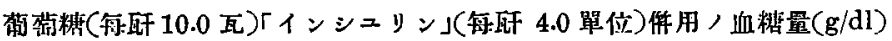

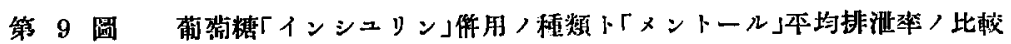

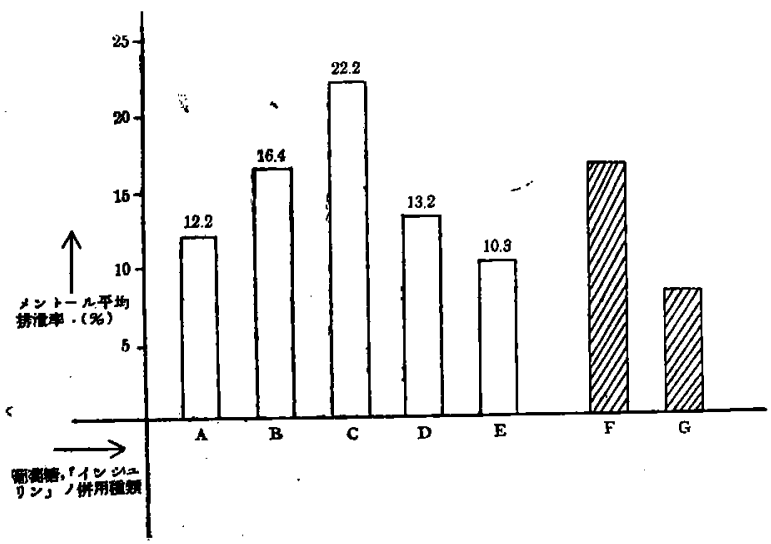

$$
\begin{aligned}
& A=\text { 「秿」5.0 瓦(繁瓦) } \\
& \mathrm{B}=\text { 「少」5.0瓦+「イ」0.5單位(") } \\
& \mathrm{C}=\text { 箱」5.0 瓦 }+\lceil 1 」 1.0 \text { 單位(") } \\
& \mathrm{D}=\lceil\text { 葡」5.0瓦 }+\lceil イ 」 2.0 \text { 單位(") } \\
& \mathbf{E}=\lceil\text { 簿」5.0瓦十「亿14.0單位 (") } \\
& \mathbf{F}=\text { 祴」5.0 瓦 }+「 1 」 1.0 \text { 單位(") } \\
& \mathrm{G}=\lceil\text { 䈻」5.0瓦 }+「 イ 」 4.0 \text { 單位(") }
\end{aligned}
$$

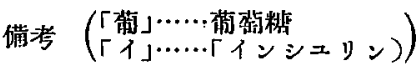


第 10 萃

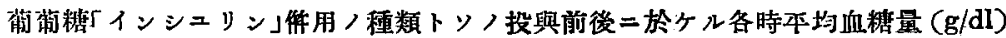

\begin{tabular}{|c|c|c|c|c|c|c|c|c|c|}
\hline 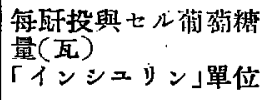 & 投與前 & $\begin{array}{l}\text { 投與後 } \\
1 / 2 \text { (時) }\end{array}$ & 1.0 & $11 / 2(\prime \prime$ & 2.0 & $\begin{array}{l}: 11 \\
3.0(11\end{array}$ & 4.0 & 5.0 & $6.0(")$ \\
\hline 葡㳦 糖 5.0 (瓦) & 0.107 & 0.159 & 0.212 & 0.254 & 0.235 & 0.230 & 0.182 & 0.156 & 0.125 \\
\hline $\begin{array}{l}\text { 葡菊 糖 } 5.0 \\
\text { 「インシュリン」 } 5.0\end{array}$ & 0.102 & 0.141 & 0.161 & 0.170 & 0.180 & 0.166 & 0.147 & 0.134 & 0.115 \\
\hline 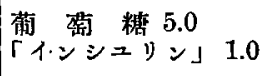 & 0.104 & 0.127 & 0.152 & 0.167 & 0.168 & 0.154 & 0.130 & 0.116 & 0.106 \\
\hline 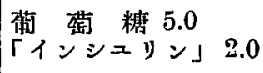 & 0.103 & 0.140 & 0.185 & 0.195 & 0.177 & 0.157 & 0.119 & 0.104 & 0.095 \\
\hline 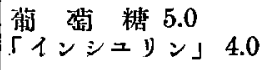 & 0.106 & 0.127 & 0.136 & 0.126 & 0.109 & 0.086 & 0.076 & 0.062 & 0.056 \\
\hline 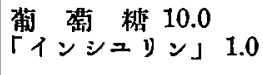 & 0.104 & 0.190 & 0.220 & 0.239 & 0.241 & 0.234 & 0.209 & 0.199 & 0.181 \\
\hline $\begin{array}{l}\text { 葡葡 糖 } 10.0 \\
\Gamma イ ン シ ュ ン 」 4.0\end{array}$ & 0.107 & 0.159 & 0.168 & 0.171 & 0.158 & 0.133 & 0.123 & 0.112 & 0.100 \\
\hline
\end{tabular}

\section{第 4 章 總括及ビ考察}

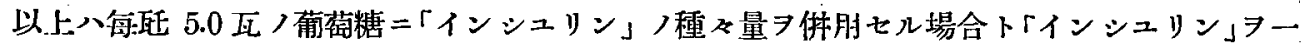
定トシ，葡萄糖 7 倍加セル場合トニ於ケル「メントール」排泄率ナリ。此/排泄率 7 指標トシテ

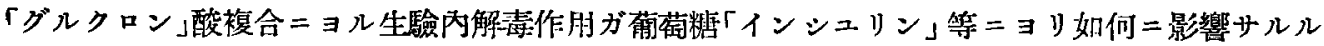

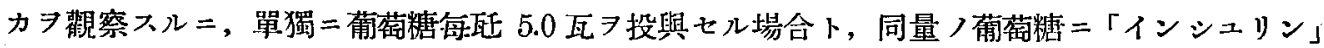

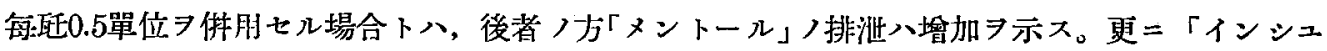

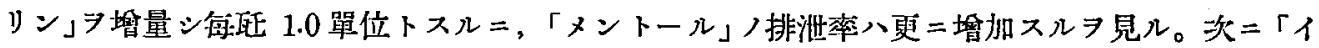

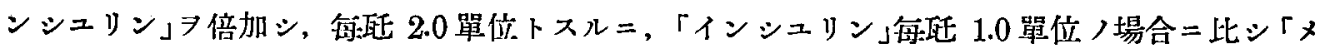

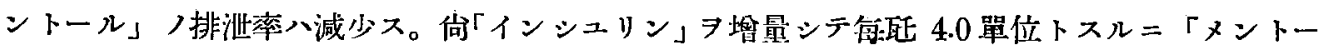

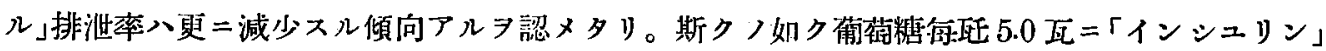
つ種

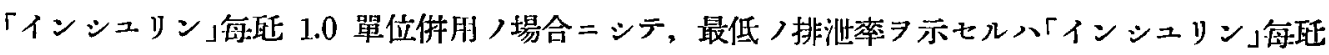

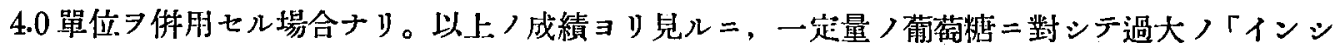

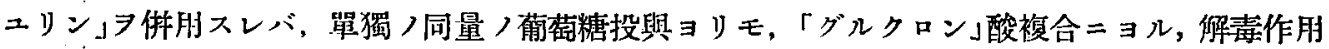
八却ツデ減弱ノ傾向ニアルモノト云フタ得ベシ。

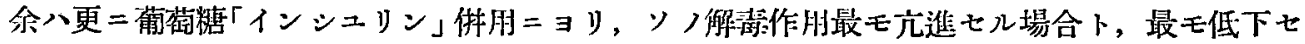

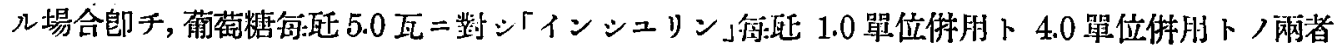

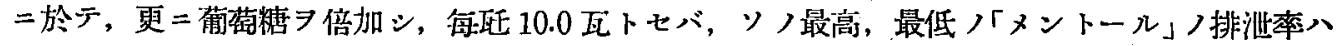
如何 $=$ 變化七ラルルヤノ疑問ノモト =, 二三實驗 7 行ヒタリ。郎チ每跴葡萄糖 5.0 瓦「インシュ リン」1.0單位投與ハ「メントール」排泄率最大ナリシニ, 今「インシュリン」量ハソノママトナシ, 
葡萄糖ノミヨ每舦 10.0 瓦トナスニ,「メントール」/排泄率八反ツテ低下ス。又最少「メントー

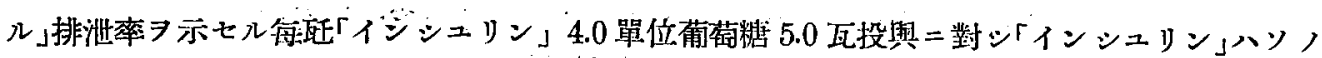

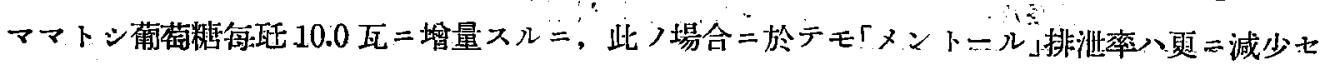

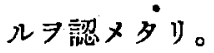

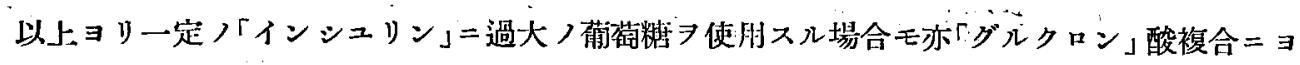
ル解珰作䏚ハ堿弱低下スル倾向アルラ認メタリ。

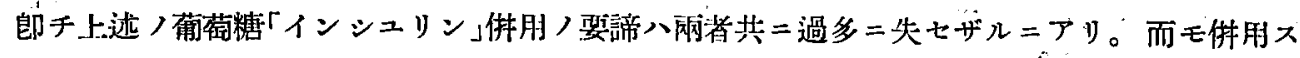

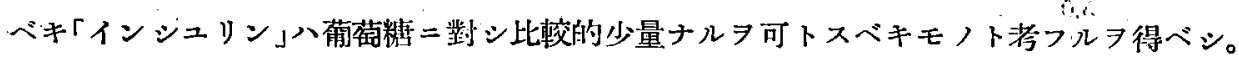

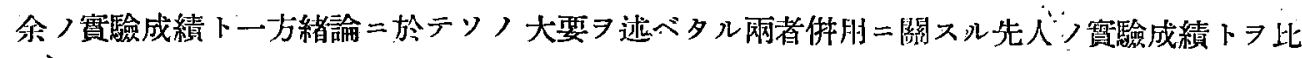
較スルコトハ, 前述セルガ如ク，ソノ實驗方法竝ニ，ソノ成績制定タル指標

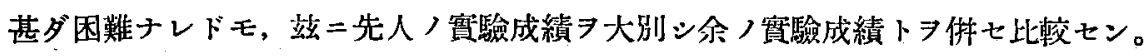

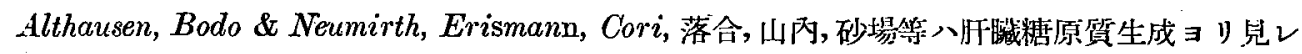
バ單獨ノ葡萄糖投與ヨリモ「インシュリン」ヨ件朋セル方有害ナリトス。又 Cori Cori, Macleod \& Cor $i$, 中村, 岡崎等八同一觀點 $ョ$ y同量 $/$ 葡萄糖 シシテ，少量ノ場合八俏利ナルタ認メタリ。更二藤原ハ「メントール」投與ニヨル「グルクロン」

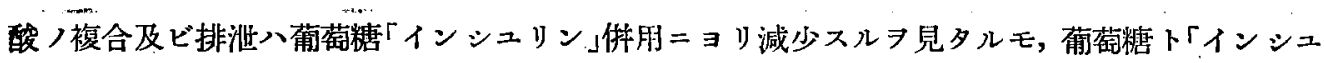
リン」ノ種及量ヨ組合ハ七タル結果ニハアラズシテ, 單二初メョリ大量ノインシュリン」ヨ使朋

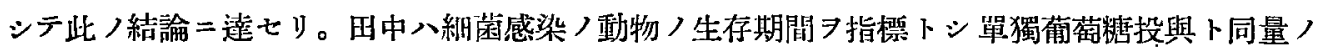

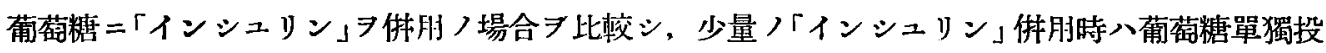
與ヨリ准利ニシテ「インシュリン」ノ大量件刖入有害ナルタ認メ，更二一定量ノ「インシュリン」 二葡萄糖ノ大量㑢肘八同樣＝侍利ナルラ知リタリ。山內モ又葡萄糖「インシュリン」ノ大量當入 䀒糖原質生成二有害ナル 7 觀察セリ。

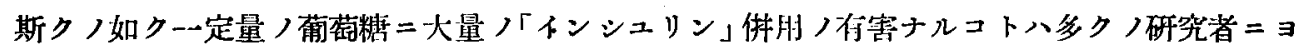
り認メラルル所ニシテ，余ノメントール，グルクロン」酸複合ヨリ見タル場合ノ實驗ト一致ス ル・見ル。

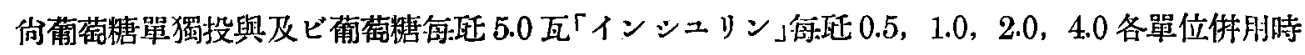

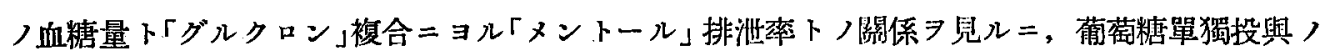

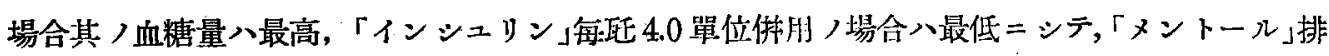
泄率ハ「インシュリン」每㱙 1.0 單位件州ノ場合八最モ充進シ，血糖量ト「グルクロン」複合ニヨ ル」解毒作朋トハソノ間何等 /關係ナキモノノ如ク見ラル。然レドモ「インシュリン」每跴 4.0 單 位肘入場合八前述入如ク，血糖量入最低，且ツ「メントール」排泄率モ最低ナルヨ見レバ血糖量 ト「メントール」排泄トハ一定〉關係二立ツモノノ如クニモ考フルヨ得。(第 11 表参照）

然リト踓へドモ「インシュリン」ノ本態站二作湖ガ米ダ明膫ナラザル今日「インシニリン」ヨ葡 
筑 11 表

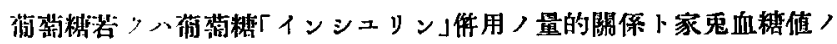

消長及ビンレト「メントール」排泄卒下,關保

\begin{tabular}{|c|c|c|c|c|c|c|c|c|c|c|}
\hline \multirow{2}{*}{\multicolumn{2}{|c|}{ 每 瓦 投 县 量投與前 }} & \multicolumn{2}{|c|}{ 血. } & \multicolumn{3}{|c|}{ 粦 } & \multicolumn{2}{|c|}{ 量 } & \multirow{2}{*}{6.0 㭙 } & \multirow{2}{*}{ 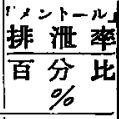 } \\
\hline & & $\begin{array}{l}\text { 投县後 } \\
1 / 2 \text { 時 }\end{array}$ & 1.0 時 & $11 / 2$ 晴 & 2.0 蛙 & 3.0 時: & 4.0 時 & 5.0 時 & & \\
\hline 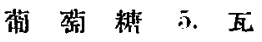 & 105 & 156 & 205 & 250 & 230 & 226 & 178 & 153 & 123 & 12.2 \\
\hline 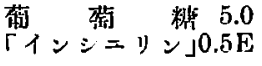 & 105 & 1.45 & 166 & 175 & 185 & 171 & 151 & 138 & 119 & 16.4 \\
\hline 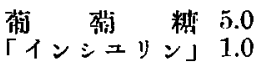 & 105 & 128 & 130 & 168 & 169 & 155 & 131 & 116 & 106 & 22.2 \\
\hline 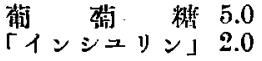 & 105 & 143 & 189 & 199 & 173 & 160 & 121 & 106 & 97 & 13.2 \\
\hline 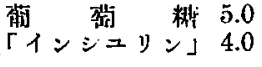 & 105 & 126 & 135 & 125 & 108 & 85 & 75 & 62 & 56 & 10.3 \\
\hline 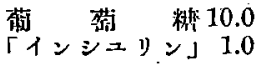 & $10 \overline{1}$ & 192 & 222 & 242 & $\mathbf{2 3 8}$ & $\mathbf{2 5 2}$ & 210 & 200 & 183 & 16.6 \\
\hline 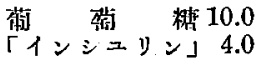 & $10 \pi$ & 1.ริ & 165 & 168 & 156 & 133 & 125 & 110 & 98 & 8.3 \\
\hline 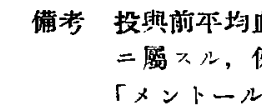 & 13. & 2 装乃 & 第 8 表 & 52例 & & 。文 & & ケル & 量八 & 一貫略 \\
\hline
\end{tabular}

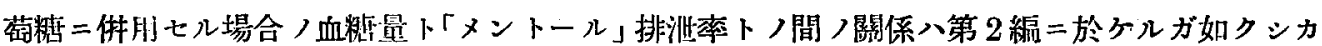
シ簡單ニ八諭ジ得ザルモノナリト信ズ。

\section{結 論（第 $1,2,3$ 編）}

尿中ノ複合「グルクロン」酸习渭定スルコトニヨリ生體內二於ケル「グルクロン」酸ノ生成殊=

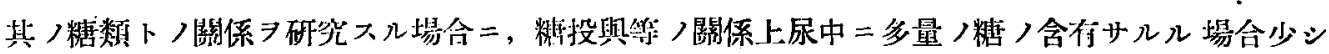

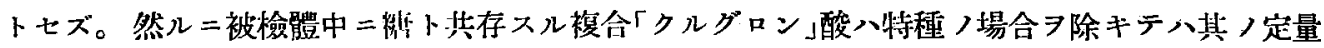
ニ著シク困難ヨ加フルモノナり。

依ツテ食八 Quick ガ「メントール,グルクロン」酸ガ「ェーテル」二可溶性ニシテ, 畨が「エー テル」二不溶性ナル性質 クン」酸ノ定最二成功セシ二想到シ「グルクロン」酸ノ複合手トシテ，「メントール」ヨ家息二投

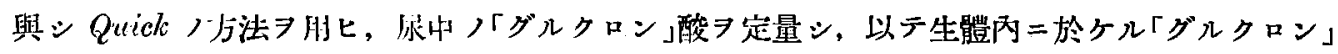

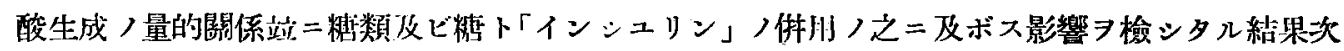
ノ結論タ积タリ。

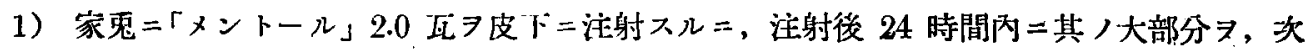
ギノ 24 時閶二, 殘リノ部分ガ「グルクロン」酸二複合サレテ尿中二排泄サル。

2）家鬼 1 日ノノグルクロン酸生成量二八树限アリ。

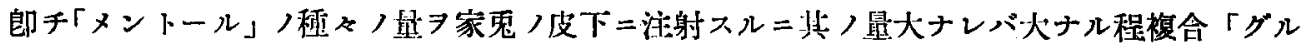


クロン」酸量八增加スルモノニアラズ。「メントール」ガ一定量以上ニナレバ複命「グルクロン」 酸量八漸次減少ノ傾向ヨ柎ス。此ノ場命「グルクロン」酸生成量が極限ヨ示スハ「メントール」3.5 瓦注射時ナリ。

3）此ノ「グルクロン」酸生成量ノ梅限以队二相當スル「メントール」量フ注射七ル場合ト踓モ, ソノ全量ガ「グルクロン」酸ト複合セラルルモノンアラズ。然レドモ其ノ極限以门量ヨ注射ス ル場合ハ「メントール」ガ假令 2.0 瓦，2.5，3.0ト其ノ量

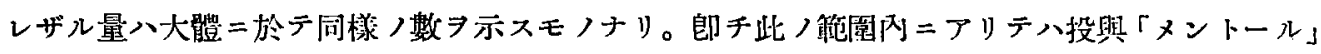

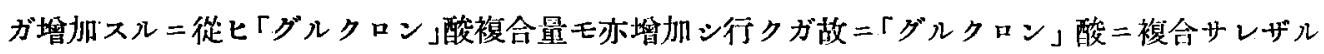
「メントール」量八常二大體同數ヨ示スモノト考へラル。

此ノ「グルクロン」酸二椱合サレザル「メントール」量八投與「メントール」量が 3.5 比超過 ス

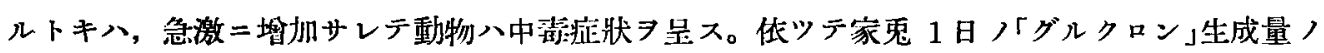

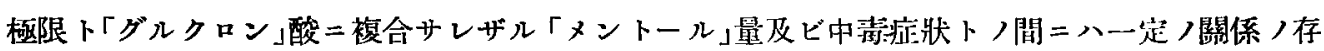
在スルヨ知ル。

4） A) 同一家鬼二一定ノ間隔ヨ以テ同一量ノ「メントール」ヨ投與スルコト，B）更＝此，

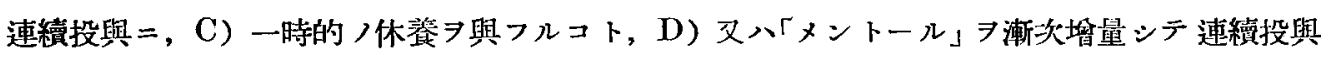
スルコト等ニヨリ家鬼 1 日ノ「グルクロン」酸生成量ノ柫限ヨシテ或程度增大セシメ得。

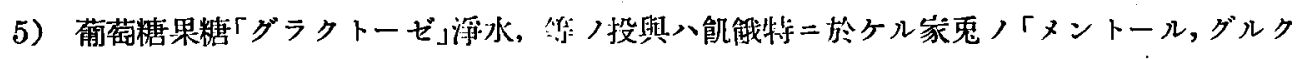

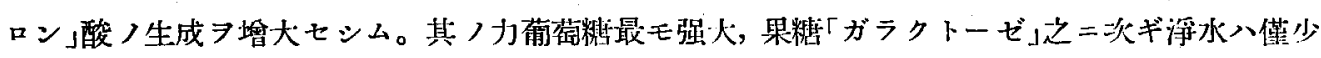
ノ作同ヨ有スルニ過ギズ。

6）葡萄糖, 果糖,「ガラクトーゼ」, 淨水八䶿解芜鬼ノ血糖量

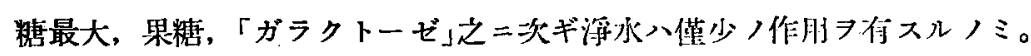

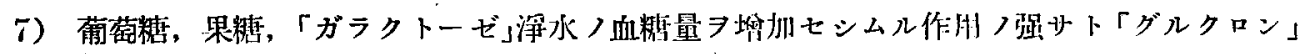
酸生成量 7 增加セシムル作胒ノ强サトハ相一致ス。

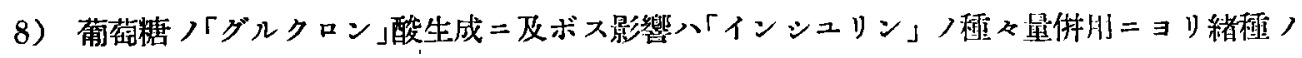

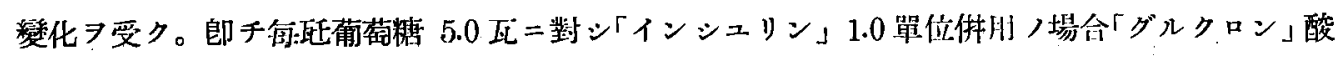

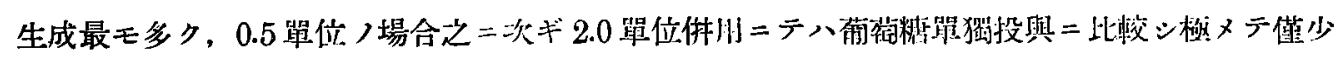

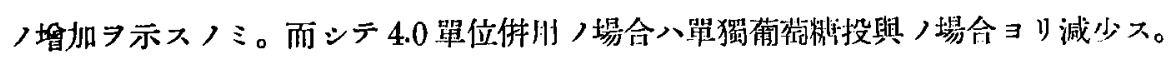

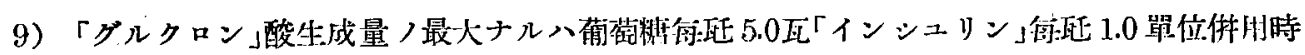

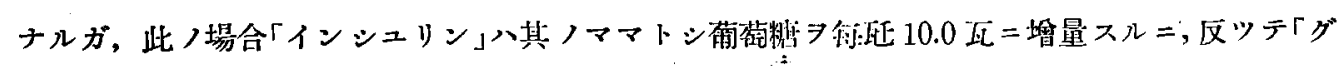
ルクロン酸生成量八減少ヨ棵七り。

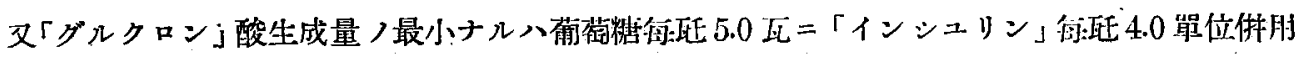

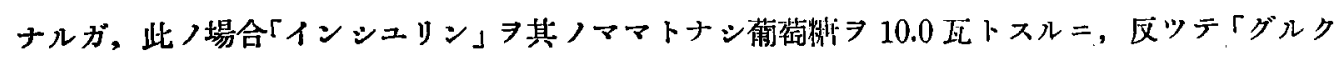
ロン」酸生成ハ減少スルァ見ル。 


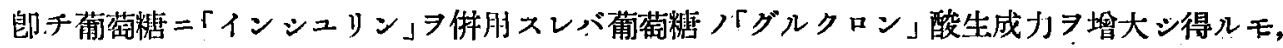

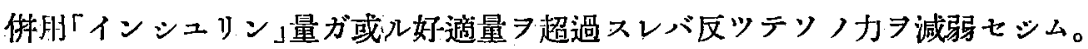

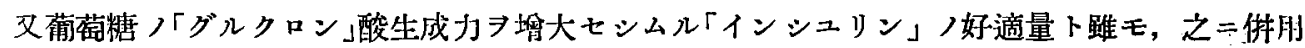
スベ手葡萄僳が過多二失スルトキハ之又其ノ「グルククロン酸生成

依ツテ葡萄糖「インシュリシ」湖朋ガ家鬼體內「グルクロン」酸生成フ增大セシムル場合つ最好 適「インシュリン」量八其〉體重二應ジ一定セれモノニシテ，之二配スベキ葡蕧糖二就キテモ亦 其ノ最好適量ノ存スルモノナルコトア知ル。

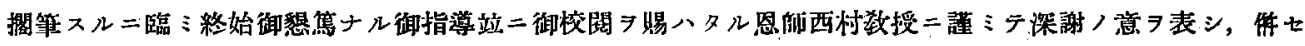
テ絕へズ御嗳助 シ睗ヘリタル数空員諸兄二感謝ス。

\section{主 要 文 獻}

(第 1 編)

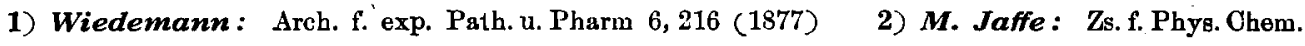
2, 47 (1878-79) 3) O. Schmiedeberg u. H. Meyer: Zs. f. Phys. Chem. 3, 422. (1879) 4) P. Mayer u. C. Neuberg: Zs. f. Phys. Chem. 29, 256 (1900) 5) Ch. Hervieux: Bull. de la Soc. Chim [4] 3, 349 (1908) 6) C. Tollens: Zs. f. Phys. Chem. 61, 95 (1909)

7) $C$.

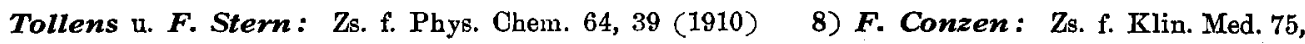
426 (1919) 9) M. Händel: Zs. f. ges. exp. Med. 42, 172 (1924) 10) J. Sauer: Klin. Wsehr. 9, 2850 (1930) 11 ) T. Pryde u. R. T. Williams : Biochem. J. 27, 1210 (1933) 12,13) P. Mayer u. C. Neuberg: Zs. f. Phys. Chemie 29, 256 (1900) 14) E. C. Leersum : Hofmeisters, Beiträge 3,522 (1903) 15) M. Bial: Zs. f. Phys. Chem. 45, 258 (1905), M. Bial: Zbl. f. Physiol. 18, 39 (1904) 16) F. Blumenthal: Bioehem. Zs. 1, 135 (1906) 17) 坂井 : 苗驗消化器病學，第10卷，第11號，17面 (1935) 18) Pick： Schmiedeberg's Arch. Bd. 33, S. 305 (1.894) 19) Embden, Glässner: Hofmeisler's Beitrüge Bd. 1, S. 310 (1902)(關接引用) 20) Gautice, Hervieux: C. r. de la Sac. de Biolg. T. 62, p. 201 (1907)(間接引用) 21) Steijskal u. Grïnwald : Wien. klin. Woch. S. 1062 (1909) 22) Chiary u. Caille: Bull et Mem. d. la Soc. med. d. Hop.d. Paris p. 37 (1921)(間接引用) 23) Händel: Zeitschr. ges. experim. med. Bd. 42, S. 172 (1924)(閒接引用) 24) Mann u. Magath: Ergeb d. Physiol. Bd. 23, Abt. 1, S.

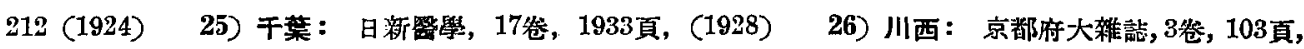
6卷, 289頁 (1929)(1932) 27) 志賀：慶想醫學, 10怣, 1號, 137頁(1930) 28) (Julius pohI): (1931) 間接引用 29) B. A. Nasarzanz：Zs. f. ges. exp. Med. 80, 11 (1931) 30) 藤原：日 本內科學會雜誌，21怣1號，67頁(1932) 31) 加藤：祭學研浼，8卷，6號，575頁(1934） 32) 坂井： 實駿消化器病學，第10缭，第11號，17頁(1935) 33) J. Pryde u.R. T. Williams : Biochem. Jour.

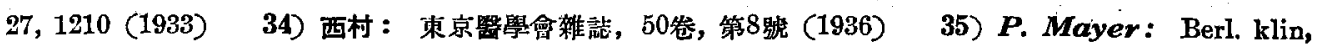
Wschr. Nr. 27 u. 28 (1899) 36) E. Külz: Zs. f. Bíol. 27, 247 (1890) 37) Flïckiger: Zs.
f. Phys Chem. 9 (1889)
38) J. Bieberfeld: Biochem. Z8. 65, 479 (1914)
39) A. J. Quick: 
Folin-Wu: Klin. Laboratorțumtechnik. (Brugsch u. Schittenhelm)(1924) 42) Händel: Zeitschr. ges: exp. Med. 42, S. 172 (1924) 43) 川西：京都府立䇴大猚誌, 3姿, 103頁, 6卷, 289頁 (1929)(1932) 44) E. Nicolas: C. r. de. Soc. de. biol. 61, 149 (1906) 45) G. Goldschmidt: Zs. f. Phys. Chem. 65, 226 u. 386 (1910) 46) P. Mayer: Berl. klin. Wschr. Nr 27 u. 28 (1899) 47) M. Bial: D. med. Wschr. 28, 25: (1902) 48) B. Tollens : Ber. d. dtsch. Chem. Gesell. 41, 1788 (1908). . 49) C. Neuqerg, Neubegr u. Mandel: Biochem. Zs. 13, 305 u. 148 (1908). 17, 270 (1909). 20, 526 (1909). $20,5: 31$ (1909). 24, 152 u. '166 (1910). 24, 436 (1910) 50) C. Neuberg u. Saneyoshi: Biochem. Zs. 36, 56 (1911) 51) C. Neuberg n. Kobel: Biocheụ Zs. 243, 435 (1931) 52) 緒方, 山冈：樂學雜誌，50卷，11號，135頁(1930） 53) Soxhlet：化

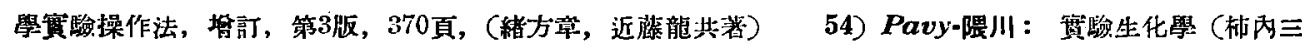
郎), 165頁(1928)

55) A. J. Quick: J. of Biol. Chem. 61, 679 (1924)

56) Fromm u.

Clemens: Zs. f. Physiol. Chem. 34, :88.5 (1901)

(第; 2 編)

57) Graham: Journ of exper, Med. 21, 185. (1915) 58) Junkersdarf: Piliglrs Archiv Bd. 186, S 254. (1921) 59) Kii!z: Arch f. exper. path 31, 398. (1893) 60) C. Voit: J. ber. Tierchens. 29. 332. (1898) 61) Kausch u. Soce?n: Arch f exrer path 31. 39S (1893) 62)

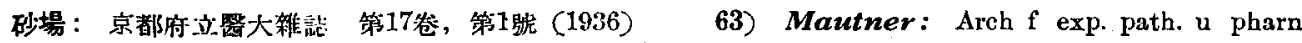
(1927) (關接引㨫) 64) Roger: These paris (1887) Wolonzew Malyo, Jahresb, 40.406 (開接引

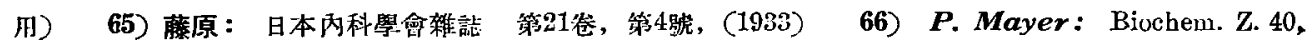
441. (1941) .

(第 3 編)

67) Richter, P. F.: Med. klin. 1981 (1924) 68) Jacoby, H.: Dtsch, Med. Wschr. Nr. 2. S. 641 (1926) 69) Grunenberg, K.: Dtsch. Med. Wschr, Nr. 7, S. 271 (1926) u. Zeitschr. f. klin. Med. Bd. 108, S. 349 (1926) 70) Rosenberg, M.: Med. Wschr. Nr. 12, S. 485 (1926) 71) Herszky, P.: Klin. Wschr. Nr. 82, s. 1473 (1926) 72) Eppinger u. Walzel: Krankheit d. Leber (1926) (關接引用) 73) Klein O.: Zeitschr. f. klin. Med. Bd. 102, S. 229 (1926) 74)

Jaksch-Wartenhorst: Münch.Med. Wschr. NJ. 38, S. 1565 (1926) 75) Schneider, H., Wien: Klin Wschr. Nr. 44, S. 1277 (1926)

76) Budde, O. : Zeitschr. f. Kinderheilk, Bd. 45, HI. 3

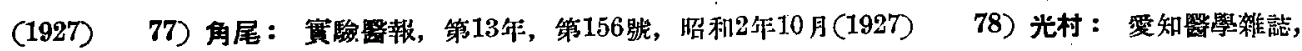
第36告，第5號，昭和3年 (1928) 79) 見玉：治療酎學雜誌，第3卷，820頁 (昭利8年)，1933 80)

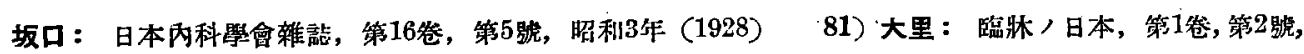

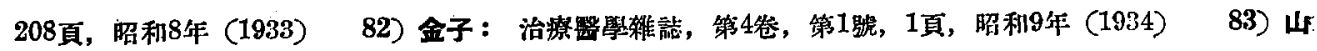

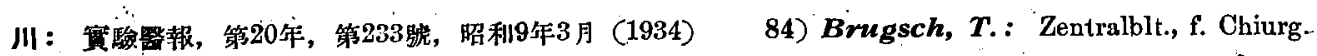
Jg. 59, Nr. 26, S. 1518 (1932) 85) Büttner: Zentralblt. f. Chiurg. Jg. 59, Nr. 26, S. 1578 (1932) 86) Kugelmann B.: Dtsch. Med. Wschr. Nr. 17, S. 651 (1932) 87) Kalk, H.: Dtsch. Med. Wschr. Nr. 30, S. 1160 (1932) 88) Babin, B. P. : Brit. Journ. of Exp. Pathol. 
4, $310(1929)$

O.: Arch. f. exp. path 121, 299 (1927)

und Insulin Berlin S. 166 (1927) (關接引用) med. 29, 459 (1926)

95) 落合：滿詶醫學雜誌, 第7卷, 589頁, 昭利2作 (1927)

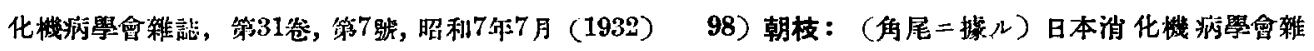

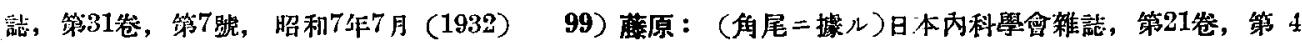

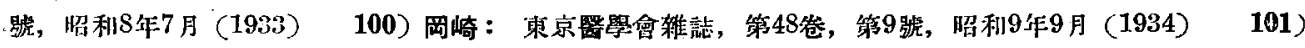

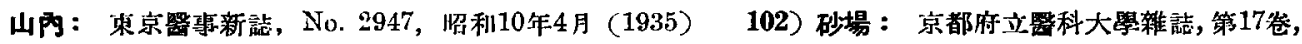
，第1频，昭利11年5月（1936）

\section{喀癌中に於ける結核菌の菒苜法}

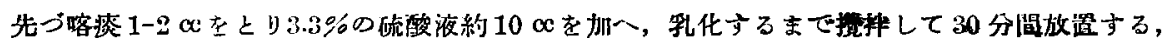

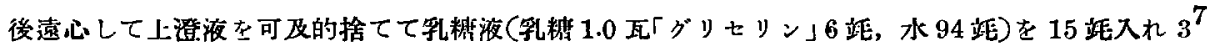

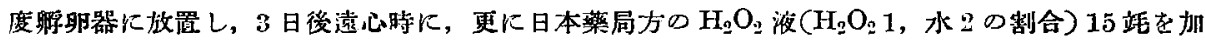

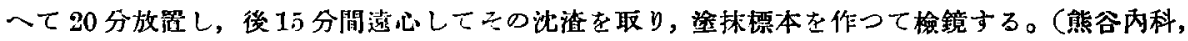
楊忘婎)

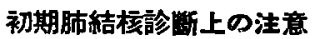

（1）一般眠往症は勿諭現病の既往店を詳細に閒き糺すこを

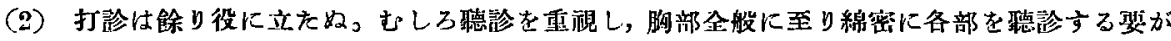

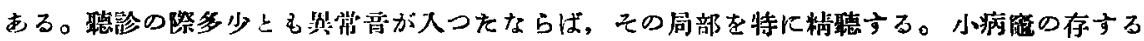

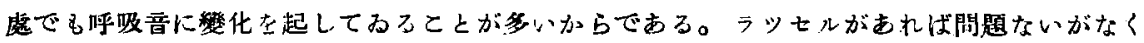
ても肺結核は澤山ある。

（3）赫沛反膲检查は必ず施行すること。

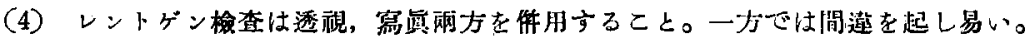

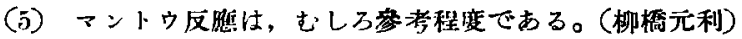

\section{肺結校に對するレオツタ氏法}

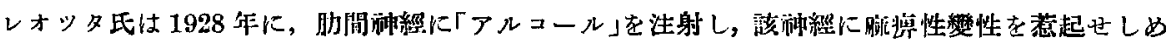

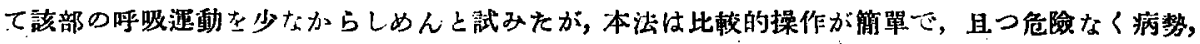

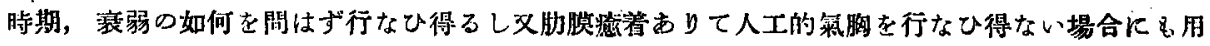

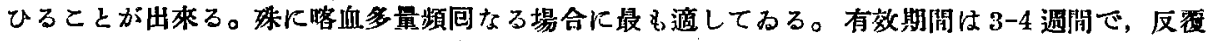
施行することが出來る。 